\title{
BIOLOGIA DE Euophrys sutrix HOLMBERG, 1874 (ARANEAE, SALTICIDAE) E SUSCETIBILIDADE DA ESPÉCIE A ACARICIDAS UTILIZADOS NA CITRICULTURA
}

\author{
LUIZ ANTONIO DA SILVEIRA MELO \\ ENGENHEIRO AGRÔNOMO
}

Orientador: Prof. Dr. OCTÁVIO NAKANO

Tese apresentada à Escola Superior de Agricultura "Luiz de Queiroz", da Universidade de São Paulo, para obtenção do título de Doutor em Ciências, Área de Concentração: Entomologia 
Ficha catalogratica preparada pela Secaro de Livroe da Divisáa de Biblioteca e Documentaça - FCledusF

Heio, Luiz Antanio de Silveira

MS2Bb Eiologia de Euophrys sutrix Holmberg. 1374

(Aिaneae, salticidae) E suscetibilidade da especie a acaricidas utilizados na citricuiturat. Firacicaba, 1794.

$11+\rho$.

TESE - ESALE

Fibliogratio

1. Acaricida - Toxidez Z. Aranta predadora Eiologia F. Arantia predadora - Efeito de acariLida 4 . Arante pare controle bialogico F. Fruta citrica - Praga - Controie tiologico I. Eecola Suberici de Agrichitura Luiz de Guejure, Firacicatia. 


\section{BIOLOGIA DE Euophrys sutrix HOLMBERG, 1874 (ARANEAE, SALTICIDAE) E SUSCETIBILIDADE DA ESPÉCIE A ACARICIDAS UTILIZADOS NA CITRICULTURA}

\section{LUIZ ANTONIO DA SILVEIRA MELO}

Aprovada em: $20 / 06 / 1994$

Comissão Julgadora:

Prof. Dr. Octávio Nakano

ESALQ/USP

Prof. Dr. Francisco de Assis Menezes Mariconi ESALQ/USP

Prof. Dr. José Djair Vendramin

ESALQ/USP

Dr. Clayton Campanhola

CNPMA/EMBRAPA

Dr. Nélson Suplicy Filho

I B / SP

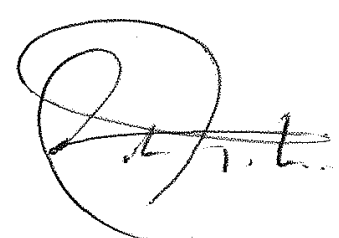

Prof. Dr. Octávio Nakano

Orient ador 
A minha esposa Maria Helena, pelo apoio e compreensão nos momentos dificeis, 


\section{AGRADECIMENTOS}

O autor agradece às seguintes pessoas e instituições:

- Prof. Dr. Octávio Nakano, pela inestimável orientação;

- EMBRAPA - Empresa Brasileira de Pesquisa Agropecuária, pela oportunidade e bolsa de estudos concedida;

- CNPMA - Centro Nacional de Pesquisa de Monitoramento e Avaliação de Impacto Ambiental, da EMBRAPA, e particularmente à sua Chefia, pelo apoio e cessão de suas dependências físicas para a realização da pesquisa;

- Laboratório de criação de moscas do Depto de Entomologia da ESALQ e Laboratório de Entomologia do CENA, pelo fornecimento de pupas de moscas e aos respectivos funcionários, pela específica orientação e gentileza;

- Pesquisadora Maria Elena Galiano, do Museo Argentino de Ciências Naturales "Bernardino Rivadavia" e Instituto Nacional de Investigación de las Ciencias Naturales, Buenos Aires, Argentina, pela receptividade, ident if icação da espécie e preciosas informações fornecidas;

- Profa Isabella Maria Piovezani Rinaldi, do Depto de Zoologia do Instituto de Biociências da UNESP, Botucatu, SP, pela atenção, apoio e informações prestadas; 
- Pesquisadores e colegas do CNPMA, Claudio Martin Jonsson e Aldemir Chaim, pelas manifestações de apoio;

- Bibliotecárias e colegas do CNPMA, Maria Amélia Toledo Leme e Nilce Chaves Gattaz, a primeira pela revisão das Referências Bibliográficas e a segunda pelas sugestões apresentadas;

- Pesquisador e colega do CNPMA, Dr.Gilberto José de Moares, pela elaboração do Summary;

- Secretárias da Área Técnica e colegas do CNPMA, Edislene Ap. Bueno Ruza e Marilza Ap. Stefanuto, pelos serviços de datilografia e digitação;

- Demais colegas e amigos do CNPMA que, de alguma forma, contribuíram na realização desta pesquisa. 


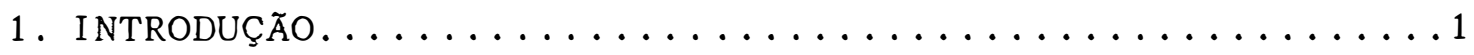

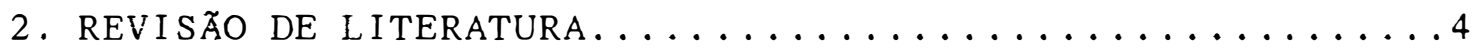
2.1. Ocorrência e importância das aranhas em culturas ...4

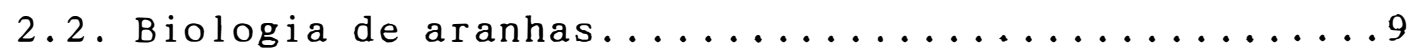
2.3. Bioecologia de aranhas.................. 11 2.4. Toxicidade/seletividade de defensivos a aranhas...12

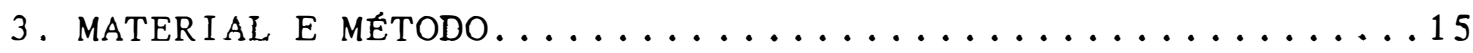
3.1. Determinação da família de aranha mais freqüente..15 3.2 . Biologia........................... 16 3.2.1. Ambiente de criação.................... 17 3.2.2. Al imentação (Presas).................20 3.2.2.1. Teste de consumo............21

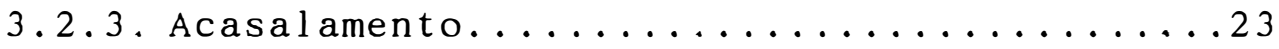

3.2.4. Estruturas-de-postura, Postura e

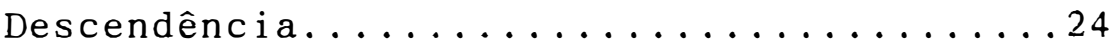

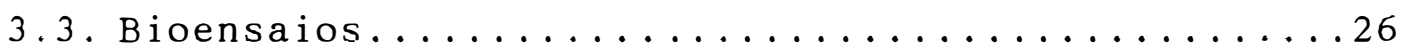

3.3.1. Caminhamento sobre filme-seco..........27

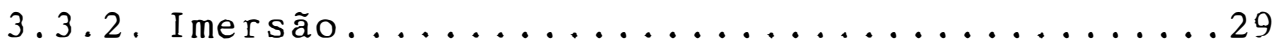

3.3.3. Exposição a filme-seco...............33 


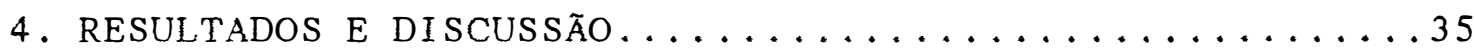

4.1. Aranhas predominantes em citros................

4.2. Desenvolvimento pós-embrionário de Euophrys

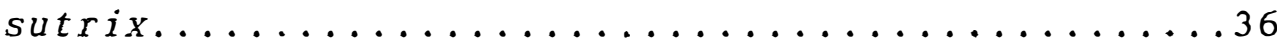

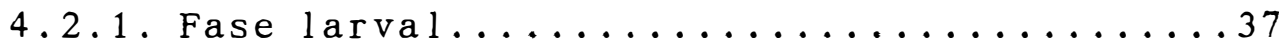

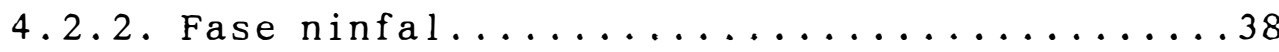

4.2.2.1. Características e Comportamento geral

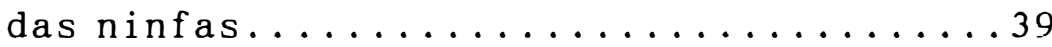

4.2.2.1.1. Coloração (caracteres).............39

4.2 .2 .1 .2 . Casulos-de-abrigo.............40

4.2.2.2. Presas e Predação (Alimentação) ........4 4

4.2 .2 .3$. Atividade....................46

4.2 .2 .3 .1 . Período inativo...............47

4.2 .2 .3 .1 .1 . Inatividade pré-ecdise..........47

4.2 .2 .3 .1 .2$. Ecdise...................49

4.2.2.3.1.3. Inatividade pós-ecdise e Período inativo total ...............55

4.2 .2 .3 .2 . Período ativo...............556

4.2 .2 .3 .2 .1 . Tamanho e Crescimento...........58

4.2 .2 .4 . Morta $1 \mathrm{idade} \ldots \ldots \ldots \ldots \ldots \ldots \ldots$

4.2.2.5. Período de vida das ninfas..........65

4.2 .3$. Fase adulta..................67

4.2.3.1. Comprimento do corpo..............69

4.2 .3 .2 . Dimorfismo sexua $1 \ldots \ldots \ldots \ldots \ldots$

4.2.3.3. Consumo de presas..............71 
4.2 .3 .4$. Reprodução..................... . . . 4

4.2.3.4.1. Acasalamento e Corte.............74

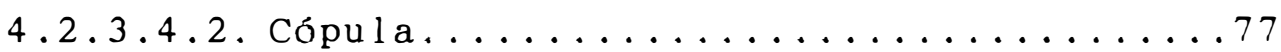

4.2 .3 .4 .3$. Casulos-de-postura.............80

4.2 .3 .4 .4$. ovissacos.................82

4.2 .3 .4 .5$. ovipos ição.................. 85

4.2 .4 . Longevidade................... 88

4.2.5. Emergência e Dispersão das ninfas........990

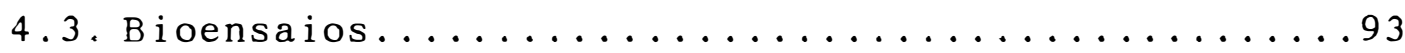

4.3.1. Caminhamento sobre filme-seco..........93

4.3 .2 . Imersão..........................

4.3.2.1. Imersão I (dosagens recomendadas) ......94

4.3 .2 .2 . Imersão I I (dosagens duplas) .........95

4.3.3. Exposição a filme-seco.............96

4.3.4. Considerações gerais dos resultados dos

bioensaios.........................

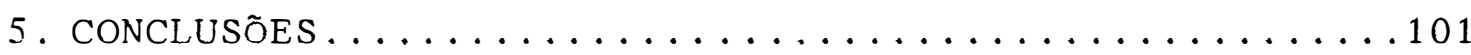

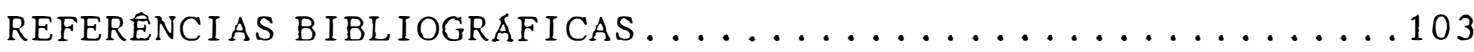




\title{
BIOLOGIA DE Euophrys sutrix HOLMBERG, 1874 (ARANEAE, SALTICIDAE) E SUSCETIBILIDADE DA ESPÉCIE A ACARICIDAS UTILIZADOS NA CITRICULTURA
}

\author{
Autor: LUIZ ANTONIO DA SILVEIRA MELO \\ Orientador: Prof. Dr. OCTÁVIO NAKANO
}

RESUMO

As aranhas são consideradas importantes predadores de insetos e seus níveis populacionais são utilizados como parâmetros na determinação da seletividade de defensivos aos inimigos naturais das pragas. Entretanto, não tem sido dada atenção às espécies de aranhas envolvidas e às suas características biológicas, que podem influenciar a ação dos pesticidas.

A biologia e a etologia de Euophrys sutrix Holmberg, 1874 foi estudada, após a determinação da família Salticidae com a mais abundante em pomares citricos do Estado de São Paulo. O estudo consistiu de observações do desenvolvimento pós-embrionário da espécie e de sua capacidade reprodutiva. Em adição, conduziram-se testes para determinar a toxicidade de acaricidas a E. sutrix.

Estabeleceu-se a criação da espécie a partir de ovos coletados em Jaguariúna, SP. Posteriormente incluíram-se na criação, ninfas capturadas na mesma região. 
Ocorreram as fases de pré-larva, larva e ninfa, constatando-se, para esta, um total de 8 ecdises. As aranhas permaneceram inativas durante cerca da metade da fase ninfal que durou 208 dias. A mortalidade ninfal foi 87\%, causada principalmente por deficiência nutricional que afetou a ecdise. A fertilidade e longevidade dos adultos também foram afetadas. Cada fêmea fértil depositou 287 ovos, que tiveram 33\% de viabilidade. A primeira postura foi a mais viável, originando $66 \%$ dos descendentes. O ciclo de vida, desde a emergência até a morte dos adultos, durou 368 dias, enquanto que o período de ovo a ovo, durou 287 dias . Entre os acaricidas testados, dicofol, $6 x$ ido de fembutatina e propargite foram inócuos a E. sutrix; bifentrim foi o mais tóxico à espécie. 


\title{
BIOLOGY OF Euophrys sutrix (ARANEAE, SALTICIDAE) AND ITS SUSCEPTIBILITY TO ACARICIDES USED IN CITRUS ORCHARDS
}

\author{
Aut hor: LUI $Z$ ANTONIO DA S ILVEIRA MELO \\ Adviser: Prof. Dr. OCTÁVIO NAKANO
}

SUMMARY

Spiders are considered important predators of insects, and their population levels constitute important parameters in the determination of the selectivity of pesticides to natural enemies of pests.

The biology and the ethology of Euophrys sutrix Holmberg, 1874 was studied in this work. This species belongs to the family salticidae, the most abundant group of spiders in citrus orchards in the state of são Paulo. The study consisted of observations on the development of the immatures and the reproduction capacity of the selected species. In addition, some tests were also conducted to determine the toxicity of different pesticides to E. sutrix.

A colony of E. sutrix was initially established with eggs collected in Jaguariuna, state of São Paulo. Later, nymphs were collected in the same region and added to the stock colony. 
The first post-embrionic stage was the pre-larva, which was followed by the larva and the nymphal stage which underwent 8 molts. Nymphs passed through quiescent periods which lasted about half the combined duration of the nymphal stage of 208 days. Nymphal mortality was $87 \%$, caused mainly by nutricional defficiency that affected molting. Adult fertility and longevity were also affected. Each fertile female laid 287 eggs, which had a viability of $33 \%$. The first batch of eggs laid was the most viable, producing $66 \%$ of the total progeny. The life cycle from egg hatching to death of the adults lasted 368 days, whereas the period from egg to egg lasted 287 days.

Among the pesticides tested, dicofol, fembutatine oxide and propargite showed no detrimental effect to E. sutrix; bifenthrin showed the highest toxicity to that species. 


\section{INTRODUÇÃO}

As plantas cítricas dão abrigo a numerosas espécies de artrópodos e, considerando a extensão das plantações, os predadores de pragas existentes na cultura devem exercer papel preponderante na manutenção do equilíbrio populacional de vários dos organismos presentes no agroecossistema.

Os artrópodos predadores de insetos têm sido mais intensivamente estudados nas últimas décadas, tendo WHITCOMB (1981) destacado sua importância como reguladores das populações de insetos.

As aranhas são importantes predadores de insetos, sendo estes suas principais presas (FOELIX, 1982; RIECHERT \& LOCKLEY, 1984). Contudo, esses autores consideraram que pequena atenção tem sido dada às aranhas em sua possível utilização no controle de pragas, devido principalmente aos poucos conhecimentos que se tem à respeito da bio-ecologia e etologia desse grupo de predadores.

Em geral, nos trabalhos sobre predadores de pragas, os espécimes de aranhas encontrados são agrupados de acordo com o hábito (p.ex. caçadoras, construtoras de 
teias etc.), em famílias e, em alguns casos, os membros da Ordem são considerados sem discriminação (WHITCOMB, 1981 ). As aranhas das diversas famílias têm, como os insetos, hábitos e comportamentos muito diferenciados e, segundo WHITCOMB (1981), duas espécies congêneres podem ter até hábitos alimentares diferentes, o que dificulta a investigação quando não se tem um mínimo de informações básicas dessas espécies, como ciclo de vida, habitat, comportamento ou dinâmica populacional.

Em outros países há um relativo conhecimento da toxicidade de defensivos a agrupamentos, a famílias e mesmo a algumas espécies de aranhas (SPECHT \& DONDALE, 1960; BOSTANIAN et alii, 1984 ; WHITFORD et alii, 1987), que são consideradas de elevada importância na manutenção do baixo nível populacional de pragas nas culturas, quando nestas são utilizados defensivos seletivos (RIECHERT \& LOCKLEY, 1984). Mas, mesmo em países desenvolvidos, ainda faltam muitas informações sobre a seletividade específica, tendo WHITFORD et alii (1987) considerado que os efeitos de inseticidas sobre espécies ou famílias de aranhas, podem ser completamente diferentes.

A seletividade de inseticidas e de acaricidas a inimigos naturais de pragas vem sendo bastante estudada, tendo sido determinados alguns defensivos que apresentam baixa toxicidade a espécies mais comuns de insetos predadores. Contudo, para aranhas, no Brasil, não há trabalhos sobre toxicidade específica e nem sequer ao nível 
de família, sendo que todos os trabalhos conhecidos citam somente toxicidade a aranhas em geral (GUILLEN, 1977; SANTOS et alii, 1978; SALVADORI \& GOMEZ, 1978; BELARMINO et alii, 1991; BERTOLDO \& CAETANO, 1991 ; LEONEL JR. et ali i, 1991; PAPA et alii, 1991 ; JOSE, 1992, entre outros).

Como os pomares paulistas têm requerido, mais frequientemente, aplicações de acaricidas para controle principalmente do ácaro-da-falsa-ferrugem e do ácaro-daleprose (CAETANO, 1980; MOREIRA, 1983), torna-se importante conhecer a atuação desses produtos sobre os artrópodos benéficos, entre eles as aranhas, porém, de maneira menos generalizada.

Desta forma, este trabalho objetivou conhecer a biologia, a partir do desenvolvimento pósembrionário, e aspectos de comportamento da espécie Euophrys sutrix Holmberg, 1874, aranha pertencente à família Salticidae, comumente encontrada em citros. Além disso, procurou-se determinar a toxicidade a esta espécie de aranha, dos acaricidas mais aplicados na cultura, visando a redução do impacto desses produtos. 


\section{REVISÃO DE LITERATURA}

o gênero Euophrys Koch, 1834 é de distribuição mundial, existindo perto de 50 espécies neotropicais descritas e havendo citação de ocorrência de 12 espécies para a Argentina e Chile (GALIANo, 1962). De acordo com a mesma autoral, o gênero Euophrys é o mesmo que Evophrys, encontrando-se, na literatura, espécies com as duas designações de gênero.

\subsection{Ocorrência e importância das aranhas em culturas}

As aranhas são de ocorrência generalizada, destacando-se, no agroecossistema, pela predação de insetos, estes muitas vezes pragas de plantas de interesse econômico. Nas culturas cujos ambientes são relativamente instáveis pela contínua ação do homem, levantamentos das aranhas têm sido realizados desde 1938, segundo WHITFORD et alii (1987).

${ }^{1}$ GALIANO, M.E. (Museo Argentino de Ciências Naturales "Bernardino Rivadavia") Correspondência pessoal, 1992. 
Em culturas mais estáveis e perenes, como pomares, onde populações de aranhas podem se refugiar mais seguramente, poucos foram os trabalhos encontrados, tendo sido mais estudados pomares de macieiras dos Estados Unidos e Canadá. Em New Jersey, EUA, encontraram-se 34 espécies de aranhas pertencentes a 13 familias, sendo 6 espécies de Salticidae (SPECHT \& DONDALE, 1960); na Virgínia, EUA, de 68 espécies de 15 famílias, 15 foram Salticidae (McCAFFrEY \& HORSBURGH, 1980) e em Quebec, Canadá, DONDALE et ali i (1979) e BOSTANIAN et alii (1984) encontraram, no mínimo, 51 espécies de 11 famílias, sendo 7 espécies de Salticidae.

A espécie estudada, Euophrys sutrix Holmberg, 1874 é uma das mais abundantes na Argentina, sendo comum sua ocorrência nas plantas cítricas; em Buenos Aires e seus arredores é também encontrada nos jardins e parques; em regiões agrestes, somente ocorre em refúgios construídos entre os ramos de ninhos de aves (GALIANO ${ }^{1}$ ).

Entre os estudiosos do assunto é indubitável que o complexo de aranhas contribui na manutenção do equilíbrio populacional da entomofauna no ecossistema. Porém, não há um consenso sobre sua eficiência na predação de insetos-pragas, embora alguns autores tenham tentado determinar sua importância, pela qualificação ou quantificação das presas.

WHITFORD et alii (1987) citaram que as aranhas foram observadas al imentando-se de diversas pragas, tais como Heliothis virescens (F.), adultos de Anthonomus 
grandis Boh., Lygus hesperus knight, pulgões, larvas de Chilo partillus (Swinhoe) e larvas e adultos de Ostrinia nubilalis (Hüb.).

Em cultura de citros em Israel, MANSOUR \& WHITCOMB ( 1986 ) observaram que em pomares "não perturbados" a população de Ceroplastes floridensis Comst. não se desenvolveu suficientemente para causar dano econômico e que as aranhas foram responsáveis pela predação da praga; depois, durante três anos em que as aranhas foram eliminadas, o número de cochonilhas aumentou grandemente. Esses autores levantaram a hipótese de que espécies da família Clubionidae (caçadoras) foram os mais efetivos inimigos naturais da praga; informaram ainda, que na Arábia Saudita duas espécies dessa família foram determinadas como sendo ativas predadoras de ovos e larvas de Papilio demodeus L. Na mesma cultura, na Cal ifórnia, CARROL (1980) considerou que os clubionídeos foram provavelmente os mais promissores inimigos naturais das pragas.

A utilização de aranhas como inimigos naturais obteve sucesso na Africa do Sul, no combate às moscas domésticas em residências; na China, algumas espécies de aranhas foram introduzidas em campos de arroz para controlarem as pragas (NYFFELER \& BENZ, 1987).

A predação por salticídeos foi estudada por alguns pesquisadores: WHITCOMB \& TADIC (1963) observaram Phidippus audax (Hentz), P.carolinensis (Peck.\& Peck.), Metaphidippus galathea (Walck.) e M.protervus 
(Walck.) alimentando-se de larvas de Hypantria cunea (Druri); HORNER (1972) considerou $M$. galathea um agente de controle de Schizaphis graminum (Rondani) em sorgo, onde sua ação causou redução na população da praga; Mc DANIEL \& STERLING (1982) citaram que $P$. audax a única espécie de Salticidae que se alimentou de ovos de $H$. virescens, obtendo que um individuo dessa aranha consumiu, no campo, em média 5, 9 ovos da praga, por dia. Uma outra espécie de Salticidae, Platycryptus undatus (De Geer), foi detectada por JENNINGS \& PASE (1986), predando adultos de Dendroctomus frontalis (Zimm.), que é um escolitídeo praga de pinheiros no Texas. CARROL (1980), observando a preferência alimentar do salticídeo Thiodina cf. T. sylvana (Hentz), verificou que os primeiros ínstares alimentaram-se de pequenos dípteros, muito raramente de pequenas vespas, ácaros e tripes, rejeitando pulgões e cochonilhas, e fugindo de formigas: os ínstares mais superiores alimentaram-se de moscas e pequenas mariposas.

BAILEY \& CHADA (1968) em estudo sobre aranhas na cultura de sorgo, realizaram testes alimentares com as espécies mais comuns, obtendo que os salticídeos Habronatus coronatus (Hentz), M. galathea e P. audax, alimentaram-se de larvas e adultos de Helicoverpa zea (Bod.) e de adultos de Contarinia sorghicola (Coq.) e que, mesmo alimentando-se dos inimigos naturais Hippodamia convergens (Guer-Menev.) e Chrysopa sp., o complexo de aranhas foi importante no controle das pragas da cultura. 
Em relação à predação de insetos inimigos naturais, HOWELL \& PIENKOWSKY (1971) determinaram, em teste de alimentação, que o salticídeo Zygoballus sexpunctatus (Hentz) não se alimentou de adultos de Crysopa sp. ou de Nabis sp. e nem de larvas e adultos de Hippodamia sp., enquanto que $P$. audax alimentou-se de todos.

A importância das aranhas na predação de insetos em pastagens, campos de cereais, pomares e florestas, foi discutida por NYFFELER \& BENZ (1987), concluindo que, à despeito de vários trabalhos sobre a ação desses artrópodos, a signifi cância das aranhas como agentes de controle natural ainda é bastante desconhecida, não havendo resultado preciso que confirme seu valor no controle biologico de pragas. Acrescentaram ainda, que os testes de preferência alimentar são falhos, pois no laboratório, certas aranhas caçadoras a lém de consumirem maior número de presas, a composição destas não corresponde à do campo.

Pode-se observar que, apesar do relativo desconhecimento da ação das aranhas no controle biológico, várias pragas de importância econômica são por elas predadas, ocorrendo, contudo, a predação indesejável de insetos que também são inimigos naturais de pragas. Entretanto, como foi visto, pode ocorrer acentuada diferença de predação (ou de preferência alimentar) entre as espécies, podendo inclusive haver algumas espécies em cujo balanço alimentar predominem os insetos pragas. 


\subsection{Biologia de aranhas}

HORNER \& STARKS (1972) citaram que o 1 o estádio pós-embrionário é subdividido em duas fases: a 1 a que vai da eclosão (saída do córion) até o início do rompimento da membrana vitelina e a $2 \underline{a}$ que vai do rompimento da membrana até a $1 \underline{a}$ ecdise real.

De acordo com FoELIX (1982), para muitas aranhas, uma pré-larva é que emerge do ovo, sendo que esse "estágio de eclosão" pode diferir em diferentes espécies. Assim, esse autor citou que Vachon ${ }^{2}$ classificou os diferentes estágios, sem considerar quando realmente a aranha eclode: o periodo larval inicia com a pré-larva (caracterizada principalmente pela imobilidade), que após o rompimento da membrana, passa para outra pré-larva ou para uma larva mais avançada; após a ecdise da larva, surge o 10 estágio completo o qual chamou de ninfa I. Os próximos estágios ninfais (juvenis) diferenciam-se principalmente pelo aumento de tamanho.

No Brasil, as aranhas foram pouco estudadas, não havendo artigos publicados sobre biologia de salticídeos.

Na Venezuela, CRANE (1948) estudou três espécies de salticídeos do gênero Corythalia, verificando

${ }^{2}$ VACHON, M. Contribution à l'étude du développement postembryonnaire des araigneés. Première note. Généralités et nomenclature des stades. Bul1. Soc. Zool. France, 82: 337,1957 . 
que o $1 \underline{0}$ e $2 \underline{0}$ instares permaneceram no interior do casulo, não se alimentando. A autora obteve a duração de cada ínstar e observou que as fêmeas tiveram um ínstar a mais, sendo o último ninfal o mais longo; a duração do período ninfal chegou até a 6 meses. Em relação à reprodução, observou que a fêmea não aceitou mais de um macho e que este acasalou-se com várias fêmeas, 2 a 3 dias após sua última ecdise. Observou ainda, terem ocorrido três posturas com 13 a 28 ovos, sendo a primeira a maior delas.

HORNER \& STARKS (1972) estudaram M. galathea no laboratório a partir de adultos e imaturos coletados no campo, que foram criados à temperatura média de $28^{\circ} \mathrm{C}$, UR de 60 a $80 \%$ e fotofase de 12 horas, sendo alimentados com larvas e adultos de Drosophila e larvas de H. zea, de acordo com o ínstar. Obtiveram que o tempo para os individuos at ingirem a maturidade foi de aproximadamente 180 dias para os machos e 193 dias para as fêmeas, tendo os adultos machos longevidade média de $184 \pm 77$ dias e as fêmeas de $222 \pm 72$ dias; as fêmeas foram monógamas e os machos polígamos e o número de ovos colocados por fêmea, por ano, foi em média de 158 em 8,3 ovissacos; o período de incubação foi de 5 a 9 dias e a mortalidade de jovens foi alta $(86 \%)$ e maior no segundo ínstar.

O período reprodutivo de exemplares de nove espécies de Phidippus, mantidos em laboratório sob temperatura de $27 \pm 2{ }^{\circ} \mathrm{C}$, UR $50 \pm 10 \%$ e fotofase de 14 horas, foi estudado por ROACH (1988) na Carolina do sul (EUA). O autor 
observou que a espécie mais comum, $P$. audax, produziu, em média 2,75 ovissacos por fêmea e 64 ovos por ovissaco, com variação de 15 a 164 ovos por ovissaco.

\subsection{Bioecologia de aranhas}

Os trabalhos que tratam da bioecologia de espécies de aranhas aparecem em outros países e são restritos a poucas espécies de salticídeos.

MERRET (1967), em estudo fenológico de aranhas, utilizando armadilhas-de-solo em área de reserva natural, verificou que fêmeas do salticídeo Euophrys frontalis (Walck.) foram mais capturadas; isto provavelmente foi ocasionado pela inversão dos papéis sexuais da espécie, isto é, as fêmeas procuravam pelos machos sedentários. Neste caso, a atividade dos machos desenvolveu-se predominantemente na vegetação, sendo pouco capturados, e a das fêmeas na superfície do solo durante a fase reprodutiva.

O tempo de desenvolvimento de aranhas é mais longo do que da maioria dos insetos. DONDALE (1977) verificou que o salticídeo M. protervus e outras espécies de caçadoras, em área de reserva natural, demoraram aproximadamente um ano para atingirem a maturidade e reprodução: havendo bastante influência da temperatura.
A
abund ância
d e
caçadores
e

predominantemente de $P$. audax, em cultura de algodão, foi influenciada pela temperatura e umidade, sendo mais 
numerosas em ano quente e seco (DEAN et alii, 1982).

A temperatura exerceu papel predominante no comportamento de Phidippus coccineus, observando-se que essa espécie, no Estado de Nevada (EUA), permaneceu, durante o inverno, no penúltimo ínstar, no interior de um casulo de hibernação sob pedras, tendo a corte e a cópula ocorrido no final da primavera e início de verão (GARDNER, 1967).

2.4. Toxicidade/seletividade de defensivos a aranhas

De acordo com RIECHERT \& LOCKLEY (1984), a colheita, aliada aos tratos culturais e aplicações de defensivos, constituíram-se na maior causa de mortalidade de aranhas. NYFFELER \& BENZ (1987) concluíram que esses artrópodos têm grande importância ecológica em pastagens e florestas que não sofrem distúrbios e que, em pomares não tratados, as aranhas foram predadores abundantes.

A toxicidade e seletividade de inseticidas e acaricidas a aranhas têm sido, geralmente, estudadas em relação ao seu complexo (Ordem Araneae). WHITFORD et alii (1987) comentaram que os efeitos sobre espécies ou mesmo famílias podem diferir completamente, como foi o caso de carbaril e fenvalerato, que não afetaram os salticídeos mas sim os espécimes de outra família.

Em pomares de maçã. o manejo de pragas e o uso de inseticidas de largo espectro, foram responsáveis pelo declínio da população de aranhas (DONDALE et alii, 
1979; BOSTANIAN et a 1 ii , 1984). Esses artrópodos foram os inimigos naturais mais suscetíveis a defensivos, pois em três pomares não tratados havia maior número deles do que em sete tratados, tendo as aranhas caçadoras se constituído no grupo mais afetado (SPECHT \& DONDALE, 1960).

Resultados de pesquisas no campo mostraram que as aranhas não foram afetadas por malatiom, mas sim por formotiom e carbaril (MANSOUR \& WHITCOMB, 1986) e provavelmente o endossulfam não teve efeito sobre elas (REICHERT \& LOCKLEY, 1984). No Brasil, PAPA et alii (1991) relataram que a população de aranhas em citros não se recompôs após 64 dias das aplicações de fempropatrina e bifentrim, ocorrendo menor efeito tóxico do carbosulfam e dicofol.

A ação específica foi determinada por ROACH (1983) para o salticídeo P. audax, obtendo que paratiom metil foi de baixa toxicidade, azinfós metil moderadamente tóxico e fenvalerato altamente tóxico. Este último resultado contrariou a afirmação de WHITFORD et ali i (1987) para a mesma família.

Os efeitos dos defensivos podem variar para uma mesma espécie, cujas populações habitam diferentes culturas da mesma região ou as mesmas culturas em diferentes regiões, devido à diversificação do manejo de pragas e dos produtos ou ingredientes ativos que são freqüentemente aplicados em cada uma. Em Israe 1, MANSOUR (1984) testou, em laboratório, populações de uma espécie de clubionídeo 
procedente de citros e de algodão, observando que a população originária de citros foi suscetível a clorpirifós sendo porém mais tolerante a malatiom (com fator de resistência de 3,3 vezes) do que a procedente de algodão. A seletividade apresentada pelo malatiom à população habitante em citros provavelmente ocorreu porque, de acordo com o autor, esse inseticida é muito utilizado na citricultura de seu país.

Uma das táticas para contornar o problema de redução da população de inimigos naturais em culturas é a utilização de defensivos seletivos, tendo Kiritani et alii ${ }^{3}$, citados por RIECHERT \& LOCKLEY (1984), demonstrado que seu uso, aliado à aplicação moderada, controlou cigarrinha-verde em arroz, porque a população de aranhas não foi dizimada pelos defensivos, tendo LASTER \& BRAZZEL (1968) observado o mesmo em algodão.

O uso racional de defensivos visando a proteção das aranhas também foi defendido por RIECHERT \& LOCKLEY (1984), para que fossem mantidas sua diversidade e densidade, responsáveis pelo efeito benéfico desse predador.

${ }^{3}$ KIRITANI, K ; KAWAHARA, S.; SASABA, T.; NAKASUJI, F. Quantitative evaluation of predation by spiders on the green rice leafhopper, Nephotettix cinctipes Uhler, by a sight-count method. Res. Popul. Ecol. Kyoto Univ., Kyoto, 13: 187-200, 1972 . 


\section{MATERIAL E METODO}

Os trabalhos foram divididos em três etapas. Inicialmente determinou-se a família da aranha cujos exemplares eram mais abundantes em cultura citrícola, após o que realizou-se a criação, para o estudo biológico da espécie Euophrys sutrix. Posteriormente, com as ninfas originárias da criação, realizaram-se bioensaios para testar sua suscetibilidade a alguns acaricidas, recomendados para a cultura de citros.

\subsection{Determinação da família de aranha mais freqüente}

A determinação foi feita por intermédio de aranhas conservadas em álcool 70\% e provenientes de dois pomares citrícolas do município de Limeira e um de Artur Nogueira, SP, onde realizaram-se levantamentos de inimigos naturais de pragas através de tratamento de choque químico, respectivamente em maio e dezembro de 1990 e em maio de 1991. Esse material foi gentilmente cedido pelo Prof. Dr. Octávio Nakano, do Departamento de Entomologia da ESALQ/USP. As aranhas coletadas em cada pomar foram agrupadas de acordo com suas principais características, 
classificando-se a família mais numerosa, e portanto predominante, sendo esta a escolhida para o estudo.

\subsection{Biologia}

o estudo biológico da espécie foi realizado a partir de casulo-de-postura (casulo-mãe) coletado em laranjeiras (citrus sinensis Osbeck cv. Valêncial de pomar comercial em propriedade localizada no município de Jaguariúna, Estado de São Paulo, em 16/08/91. O casulo foi levado ao laboratório de Entomologia do Centro Nacional de Pesquisa de Monitoramento e Avaliação de Impacto Ambiental (CNPMA) da EMBRAPA, no mesmo município, para o desenvolvimento da criação.

Em outras quatro ocasiões (em 30/12/91; 06, 15 e 28/01/92) foram acrescentados à criação, indivíduos jovens coletados na mesma localidade anterior. Foram observados: alimentação ; comportamento durante o desenvolvimento; tamanho e comprimento do corpo em cada ínstar; crescimento; número de ínstares e sua duração; ecdises (idade, intervalo, duração); atividade; mortalidade; duração das fases jovens e adulta; acasalamento, corte e cópula; comportamento pré e póscópula; reprodução (época de construção de casulos de postura e suas características, duração da oviposição, número de casulos, de ovissacos e de ovos produzidos, tamanhos de casulos-de-postura, de ovissacos e de posturas); 
fecundidade e descendência (número de descendentes; época e duração da dispersão).

As designações das formas jovens foram de acordo com a classificação de Vachon ${ }^{2}$, citado por FOELIX (1982), preferindo-se utilizar o termo "jovem" ao invés de "juvenil".

\subsubsection{Ambiente de Criação}

As aranhas (ninfas) emersas do casulo foram mantidas em recipientes plásticos incolores confeccionados a partir de garrafas plásticas PET (tereftalato de polietileno) de 2 litros.

Dois tipos de recipientes foram utilizados: um com a metade superior da garrafa lrecipiente PET com gargalol e outro com a metade inferior, sem o fundo (recipiente PET tubular). A influência desses recipientes . na criacão, joi observada a partir da fase reprodutiva.

Os recipientes do tipo gargalo tinham cerca de $17 \mathrm{~cm}$ de altura, incluindo o gargalo, e diâmetros de $10 \mathrm{~cm}$ na base e de $2 \mathrm{~cm}$ na "boca" do gargalo. Nos do tipo tubular a altura era de 12 a $13 \mathrm{~cm}$ e diâmetro de $10 \mathrm{~cm}$. Ambos os tipos continham um orifício de $13 \mathrm{~mm}$ de diâmetro, localizado aproximadamente na metade da altura nos do tipo gargalo e a 2/3 da altura nos do tipo tubular. Na parte de cima, foram vedados com tela de "polyester" e, inferiormente, com placa circular de uma espuma 
plastificada, de cor branca, maleável e lavável. O orifício foi vedado com chumaço de algodão hidrófilo, constantemente molhado com água destilada (Figura 1).

Pela base, retirando-se a placa circular, foram realizadas atividades diárias (limpeza das paredes internas, remoção de presas mortas e de excesso de fios de seda, sendo a placa periodicamente trocada para limpeza das excreções impregnadas), de acasalamento e de manipulação dos descendentes.

Pelo orifício foram introduzidas as aranhas e suas presas e o algodão molhado proporcionava água, principalmente para as presas, e uma certa umidade interior, mesmo porque algumas espécies de aranhas são sensíveis à falta de umidade (KASTON \& KASTON, 1953). Das aranhas emergidas, 104 foram utilizadas no estudo. Estas foram distribuidas, inicialmente, em número variável por recipiente PET, ou seja: 19 recipientes contendo uma aranha, 21 contendo duas, 3 contendo três, 6 contendo quatro e 2 recipientes contendo 5 aranhas. Posteriormente, quando as observações se tornaram difíceis, devido à diferenciação no desenvolvimento, as aranhas foram gradativamente separadas, até serem totalmente individualizadas.

As aranhas emergidas permaneceram durante cerca de 3 meses (94 dias) em sala com fotofase de 13 horas, temperatura de $24 \pm 4^{\circ} \mathrm{C}$ e umidade relativa de $70 \pm 10 \%$. Após esse periodo, foram passadas para sala climatizada, com 
temperatura de $25 \pm 1,5^{\circ} \mathrm{C}$, umidade relativa de $70 \pm 10 \%$ e fotofase variável, de 11 a 14 horas, conforme a estação do ano que atravessaram. Estes últimos dados foram considerados como predominantes na criação, em decorrência do comprimento do ciclo das aranhas.

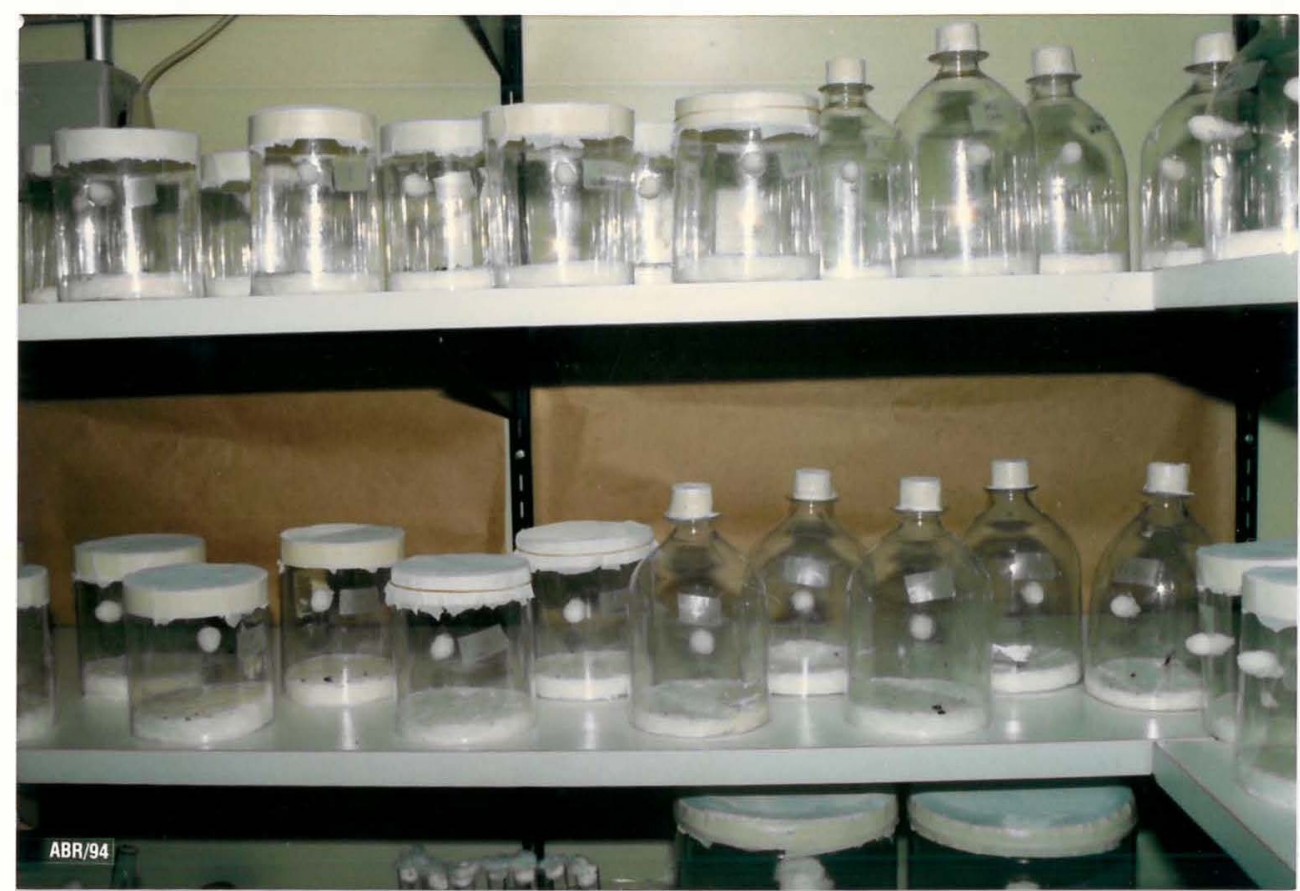

Figura 1. Recipientes de criação (recipientes PET) de Euophrys sutrix estando à esquerda os tubulares e à direita os "com gargalo".

As aranhas incluídas na criação, em número de 27, foram coletadas em média 148 dias (136 a 164dias) após a coleta do casulo-mãe e permaneceram individualizadas, no mesmo ambiente já descrito. 


\subsubsection{Alimentą̧ão (Presas)}

O al imento constituiu-se de presas vivas, observando-se a preferência a limentar dos ínstares iniciais, fornecendo-se diversos insetos de pequeno porte, coletados com rede de varredura, ou seja, vaquinhas, dípteros, ortópteros, lepidópteros, cigarrinhas, formigas, Chrysopa sp. e Cycloneda sanguinea (L.).

Às ninfas de 1 o e 2 o instares, forneceramse pequenos insetos, notadamente dípteros e cigarrinhas, coletados com rede de varredura. A partir do 30 ínstar, a alimentação foi exclusivamente de adultos de Drosophyla sp., criados em banana-nanica, oferecendo-se, a cada vez, de 3 a 4 indivíduos por aranha. Esta dieta permaneceu até quando a maioria das aranhas encontrava-se no 70 instar. Depois disso, gradativamente introduziram-se adultos de Musca domestica L. (pupas originárias de criação no Departamento de Entomologia da ESALQ) em número de duas por aranha, a cada dois dias. Após cerca de 40 dias (perto do 80 ínstar), ofereceram-se, juntamente com Musca, adultos de Ceratitis capitata (wied.) (pupas originárias de criação no Centro de Energia Nuclear na Agricultura - CENA), em número de duas Ceratitis e uma Musca, por aranha, durante aproximadamente 30 dias, a fim de diversificar a dieta. Após esse período, voltou-se a fornecer somente Musca.

Aos descendentes, originários da criação, foram fornecidos somente adultos de Drosophyla. 


\subsubsection{Teste de Consumo}

Para estabelecer o consumo diário de presas (Drosophyla para aranhas de $2 \underline{0}$ instar e Musca para as demais) foram realizados sete testes com aranhas originárias da criação, de diferentes idades ou fases: ninfas de 20 e de último ínstar; adultos virgens, machos e fêmeas; machos acasalados; fêmeas em fase de pré-oviposição e fêmeas em final de ciclo.

As presas foram fornecidas de forma a manter constante o número de insetos vivos.

\section{a) Ninfas do 20 instar (descendentes)}

Esse teste foi realizado em duas etapas, com duração de 8 dias. encerrando-se quando 44,07\% e 23,40\% das aranhas encontravam-se ativas, respectivamente na $1 \underline{a}$ e 2a e tapas.

Na 1 a etapa utilizaram-se 59 aranhas e na segunda 47 , sendo divididas em grupos que variavam de 8 a 11 aranhas por recipiente PET.

b) Ninfas do último instar

Somente 3 a ranhas, individualizadas, foram utilizadas, encerrando-se o teste após 18 dias. 


\section{c) Machos e fêmeas virgens}

Os dois destes duraram 18 dias, sendo utilizados 4 machos com idade em média de 70 dias $(61$ a 75 dias) e 3 fêmeas com idade em média de 2 dias ( 1 a 3 dias).

\section{d) Machos acasalados}

Utilizaram-se 11 machos com idade, em média, de 77 dias (19 a 111 dias), após cerca de 50 dias ( 8 a 86 dias) do acasalamento. Foram realizadas observações durante 18 dias e os dados obtidos foram, em adição, agrupados por faixa etária dos indivíduos e por faixa de período decorrido desde o acasalamento.

e) Fêmeas em fase de pré-ovoposição

Foram testadas 13 fêmeas, com idade, em média, de 51 dias $(7$ a 92 dias), após cerca de 43 dias ( 1 a 86 dias) do acasalamento. O teste teve duração de 18 dias, observando-se as mesmas faixas etárias descritas anteriormente.

f) Fêmeas em final de ciclo

Observaram-se 9 fêmeas, cuja média de idade foi de 206 dias ( 170 a 232 dias), durante 14 dias. 


\subsubsection{Acasalamento}

Para a formação do casal, os recipientes do macho e da fêmea foram abertos pelos fundos, acoplando-os verticalmente, de forma que o recipiente da fêmea ficou superiormente, na posição normal, e do macho inferiormente, na posição invertida, para que este, quando atraído, subisse pelas paredes, encontrando a fêmea.

os acasalamentos foram realizados procurando-se parear primeiramente os adultos de mais idade. Não ocorrendo reação favorável de ambos os sexos, foi feita a separação e outro macho foi colocado em contato com a mesma fêmea; persistindo a não ocorrência, a fêmea foi reservada para futuro acasalamento.

Quando ocorreu reação favorável e o macho encaminhou-se para a fêmea, os recipientes foram desacoplados e observou-se todo ritual e corte, até a ocorrência (ou aparente ocorrência) da cópula, cronometrando-se a duração do evento.

Após a aparente cópula (não foi possível observar todas as cópulas), o macho foi separado: fez-se o reacoplamento dos recipientes, de maneira inversa ao acoplamento, ou seja, o recipiente da fêmea ficando inferiormente, para que o macho retornasse, subindo, por si ou forçosamente, para seu recipiente.

Nos casos em que houve dúvida quanto à deposição do esperma, observou-se o poro genital da fêmea e, 
confirmando-se a não efetivação, novo acasalamento foi realizado.

Algumas das fêmeas copuladas foram colocadas novamente em contato com machos (com o primeiro e com outros), para verificar a aceitação de nova cópula.

Após a fase de acasalamento, os machos e as fêmeas não fertilizadas continuaram sendo normalmente alimentados até a morte, para determinar sua duração; as fêmeas fertilizadas foram observadas principalmente no tocante à construção das estruturas de postura (casulos-depostura e ovissacos) e ao comportamento na oviposição e na dispersão dos descendentes. Após isto, as observações prosseguiram até a morte de cada indivíduo.

\subsubsection{Estruturas-de-postura, Postura e Descendência}

As estruturas de postura, ou sejam, casulos de postura e ovissacos, foram contados e observados internamente, após o encerramento das dispersões e morte da f êmea.

As camadas de seda que envolviam os casulos de postura foram removidas, retirando-os com pinça e colocando-os em placas de Petri contendo álcool 70\% (o álcool reduziu a pegajosidade da seda, facilitando o manuseio e, ao mesmo tempo, ocasionou transparência das suas camadas, permitindo visualização do interior). A seguir, os casulos foram classificados quanto à forma plana e seus 
tamanhos foram obtidos tomando-se as medidas do comprimento e da maior largura.

Abrindo-se o casulo, por intermédio de pinça e tesoura, retiraram-se de seu interior os ovissacos e/ou os "restos" (exúvias de aranhas, aranhas mortas, restos de ovos, ovos soltos). As aranhas mortas e os ovos foram contados e os ovissacos, distendidos em álcool, foram medidos como anteriormente descrito, medindo-se, também, a área ocupada pelo bloco de ovos (postura inviável).

Os ovissacos foram abertos, puxando-se, ao mesmo tempo, dois de seus lados e expondo a postura ( inviável) ou os restos da postura viável, contando-se o número de ovos, de formas larvais (pré-larva e larva) e de ninfas mortas.

Os ovos foram classificados de acordo com o estágio em que se encontravam, caracterizado por coloração diferente e pela presença de uma forma pós-embrionária (prélarva).

O número de ovos por postura e o total por aranha, foi obtido pelo somatório do número de aranhas emersas, de aranhas mortas e de ovos, presentes nos ovissacos e à sua volta.

Durante todo esse processo, utilizou-se microscópio estereoscópico, com luz incidente sobre fundo preto.

As ninfas descendentes foram observadas quanto ao comportamento de emergência dos casulos e 
dispersões, contadas e passadas, em grupo de até 10 indivíduos, para novos recipientes PET. Foram alimentadas com adultos de Drosophyla sp., até o 3o ínstar e utilizadas em bioensaios ou liberadas no ambiente.

\subsection{Bioensaios}

Ninfas de $2 \underline{0}$ e $3 \underline{0}$ ínstares foram submetidas ao contato direto ou indireto de alguns acaricidas, comercialmente formulados, registrados e recomendados pela CATI (1991) para aplicação em citricultura, contra ácaro-da-falsa-ferrugem (Phyllocoptruta oleivora (Ash.) e ácaro-da-leprose (Brevipalpus phoenicis (Geij.)). As dosagens utilizadas basearam-se naquelas indicadas para controle da primeira espécie.

Os ingredientes ativos e respectivos produtos comerciais testados foram: abamectim (Vertimec 18 CE), bifentrim (Talstar $100 \mathrm{CE}$ ), cihexatim (Sipcatim 500 SC), dicofol (Kelthane CE), óxido de fembutatina (Partner) e propargite (Omite 720 CE BR).

As testemunhas continham água destilada e as diluições também, adicionando-se ou não, de acordo com o teste, o espalhante-adesivo "Agral" (nonil fenoxi poli (etilenoxi) etanol $200 \mathrm{~g} / \mathrm{l}$ ), na dosagem de $0,1 \mathrm{~g}$ i.a por litro de água $(0,5 \mathrm{ml}$ p.c./1).

Três tipos de testes foram realizados: (1) caminhamento sobre filme-seco, (2) imersão em emulsão e (3) 
exposição a filme-seco, tendo cada um, objetivo específico. No primeiro, procurou-se determinar a toxicidade a ninfas de $2 \underline{0}$ e $3 \underline{0}$ ínstares, que simplesmente caminhassem por uma superfície ou área tratada; no segundo, procurou-se verificar se uma rápida imersão na calda, simulando um banho ocorrido durante pulverizações a alto volume, afetaria

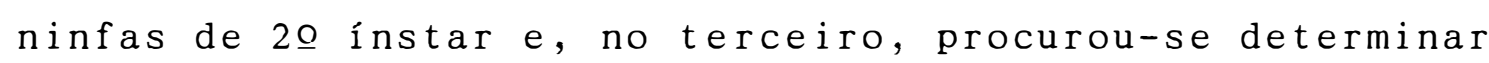

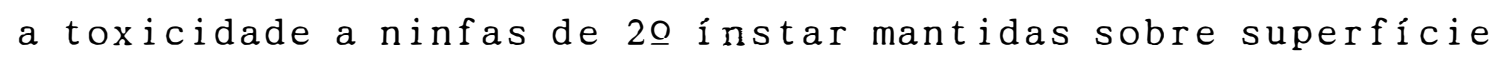
tratada.

Os dados das avaliações de toxicidade aguda (até $24 \mathrm{~h}$ ) obtidos no segundo e terceirotestes, foram transformados para $1 \mathrm{x}+0,5$ e submetidos à análise de variância com aplicação de teste $F$ ao nível de $1 \%$ de probabilidade. A comparação das médias foi feita pelo teste de Tukey a $5 \%$ de probabilidade.

Os acaricidas testados foramclassificados quanto à toxicidade, segundo as recomendações de HASSAN et alii (1987): (1) inócuo, para mortalidade menor que 50\%; (2) levemente tóxico, de 50 a $79 \%$ de mortalidade; moderadamente tóxico, de 80 a $99 \%$ e (4) tóxico, para mortalidade maior que $99 \%$.

\subsubsection{Caminhamento sobre filme-seco}

Para esse efeito, utilizaram-se tubos de PVC rígido, de cor preta, com diâmetro de 1,9 cm e comprimento de $50 \mathrm{~cm}$ : tratados internamente, sendo o método 
de aplicação definido por prévios testes de molhamento das paredes internas dos tubos.

A aplicação foi realizada com "pelota" de a lgodão hidrófilo, molhada na respectiva calda e passada ao longo do tubo.

Realizaram-se sete tratamentos, cada um constituído de um tubo tratado, tendo-se adicionado espalhante-adesivo às caldas. Os tratamentos e respectivas dosagens em g i.a./l e ml de p.c./l de água, foram:

abamectim $(0,0036 ; 0,2), \quad(2)$ bifentrim $(0,02 ; 0,2)$,

cihexat im $(0,25 ; 0,5),(4)$ dicofol $(0,1424 ; 0,77)$, ( 5) óxido de fembutatina $(0,4 ; 0,8) ;(6)$ propargite $(0,72 ; 1,0)$ e $(7)$ testemunha $\left(\mathrm{H}_{2} \mathrm{O}+\right.$ espalhante $)$.

Após as aplicações, os tubos foram fixados em um suporte, que foi mantido em posição oblíqua (cerca de $\left.45^{\circ}\right)$, com um dos lados voltado para uma fonte de ventilação em temperatura ambiente de $25^{\circ} \mathrm{C}$, por 30 minutos, para secagem. Isto feito, o suporte foi instalado de modo que os tubos permanecessem na posição vertical e encaixaram-se, em suas extremidades superiores, pequenos recipientes de plástico incolor, com $10 \mathrm{~cm}$ de comprimento e $2,5 \mathrm{~cm}$ de diâmetro, fechados superiormente com tela de "polyester". Estes recipientes tiveram a função de recepção das ninfas que chegaram ao topo dos tubos.

o ensaio foi realizado em duas etapas. sendo a primeira com ninfas de $2 \underline{\text { instar }}$ e a segunda com ninfas de 30 instar, utilizando 5 ninfas de cada instar por 
tratamento. As aranhas foram colocadas em frascos de vidro incolor (envoltos com papel alumínio para escurecimento interior), cujas "bocas" foramintroduzidas nas extremidades inferiores dos tubos. Após a chegada da maioria das ninfas nos recipientes coletores, estes foram retirados. Verificando-se a não permanência de qualquer ninfa no interior dos tubos, passou-se à segunda etapa.

As ninfas dos recipientes coletores foram passadas para recipientes PET tubulares e mantidas em sala com temperatura de $24 \pm 2{ }^{\circ} \mathrm{C}$, procedendo-se as avaliações 24 , 44 e 50 horas após o início da liberação nos tubos.

\subsubsection{Imersão}

Dois ensaios foram realizados, constituindo-se o primeiro (Imersão I) de sete tratamentos (os mesmos produtos e dosagens de teste de "Caminhamento") e quatro repetições (Tabela 1), distribuídos inteiramente ao acaso. No segundo ensaio (Imersão II), realizado com seis tratamentos e quatro repetições e método semelhante ao I. excluiu-se o bifentrim e repetiram-se os demais ingredientes ativos testados no primeiro ensaio, mas em dosagens duplas (Tabela 1). O objetivo, foi o de verificar se o grau de toxicidade observado foi devido à dosagem do produto ou, possivelmente, ao seu ingrediente ativo. 
Tabela 1. Tratamentos (ingredientes ativos) e dosagens, utilizadas nos bioensaios Imersão I e II.

\begin{tabular}{|c|c|c|c|c|}
\hline \multirow{2}{*}{$\begin{array}{l}\text { Tratamentos } \\
\text { (i.a.) }\end{array}$} & \multicolumn{2}{|c|}{ Imersão I } & \multicolumn{2}{|c|}{ Imersão II } \\
\hline & $g$ i.a/l & $\mathrm{ml}$ p.c./1 & $\mathrm{g} i \cdot a / 1$ & $\mathrm{~m} 1 \mathrm{p} . \mathrm{c} \cdot / \mathrm{l}$ \\
\hline 1. abamectim & 0,00360 & 0,20 & 0,00720 & 0,40 \\
\hline 2. bifentrim & 0,00200 & 0,20 & - & - \\
\hline 3. cihexatim & 0,25000 & 0,50 & 0,50000 & 1,00 \\
\hline 4. dicofol & 0,14245 & 0,77 & 0,28490 & 1,54 \\
\hline 5. ox. fembutat ina & 0,40000 & 0,80 & 0,80000 & 1,60 \\
\hline 6. propargite & 0,72000 & 1.00 & 1,44000 & 2,00 \\
\hline 7. testemunha & - & - & - & - \\
\hline
\end{tabular}

As caldas, sem espalhante-adesivo, foram colocadas em copos plásticos, onde mergulharam-se gaiolinhas (uma por parcela) confeccionadas a partir de pedaços de tela de "nylon""mesh" 22 (Figura 2) contendo 2 ninfas de 20 ínstar. Após 5 segundos de imersão, as gaiolinhas foram retiradas das caldas e as ninfas, depois de serem "enxugadas" com fita de papel de filtro, foram passadas para pequenos tubos plásticos de $6 \mathrm{~cm}$ de comprimento e $1,9 \mathrm{~cm}$ de diâmetro, contendo tela de "polyester" nas duas aberturas. 


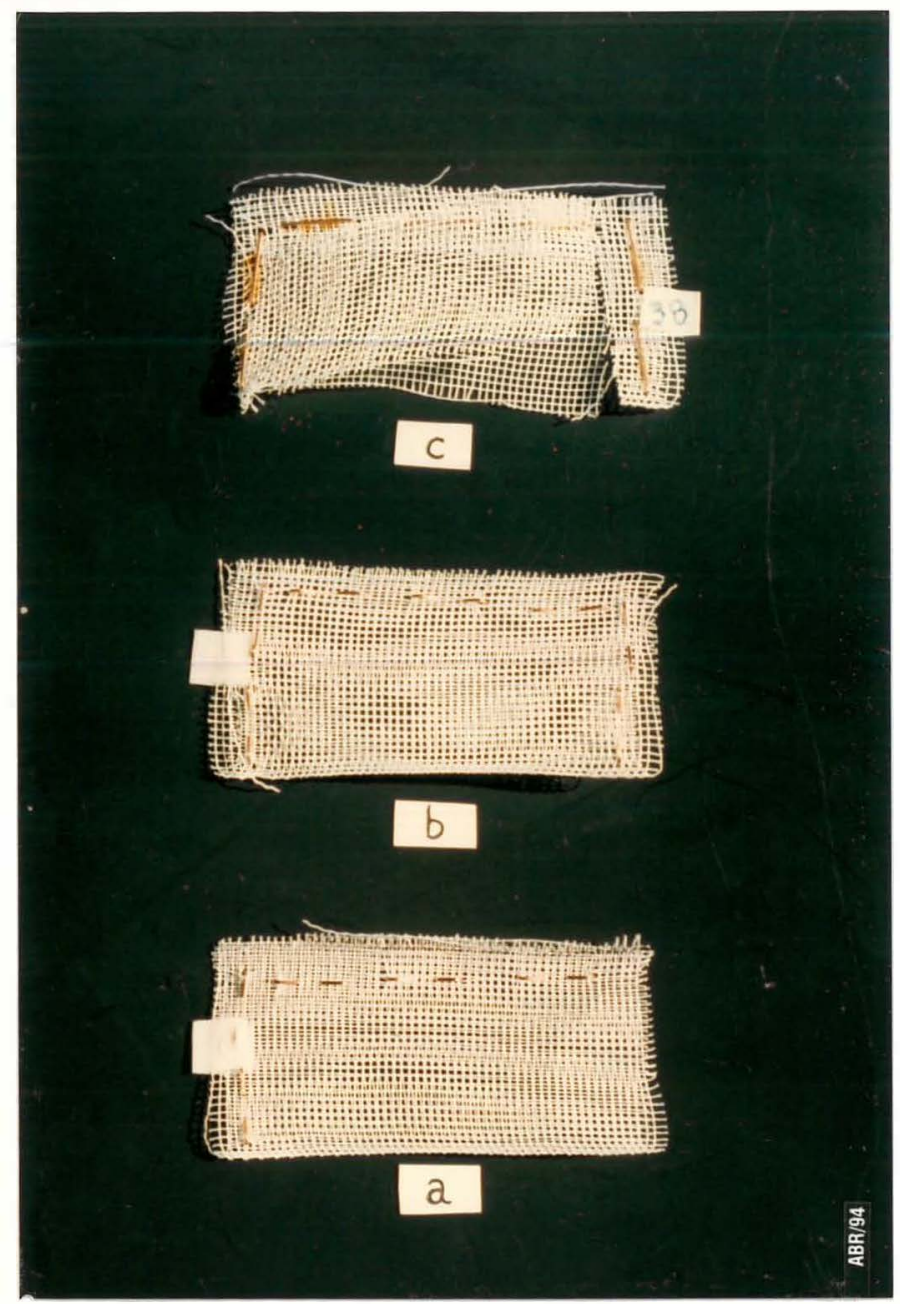

Figura 2. Gaiolinhas de tela de "nylon" utilizadas no teste de Imersão: (a) com uma face aberta para inserção das ninfas; (b) fechada, pronta para a imersão e (c) recortada em duas laterais para a retirada das aranhas tratadas.

Os tubos plásticos contendo as ninfas tratadas foram colocados em posição horizontal, em um suporte confeccionado para tal fim, de modo a receberem ventilação direta proveniente de fonte externa. O suporte 
com os tubos (Figura 3) foi mantido em sala com temperatura de $24 \pm 2{ }^{\circ} \mathrm{C}$ por 24 horas, após o que realizou-se a $1 \underline{a}$ avaliação de mortalidade.

Os efeitos sub-letais dos tratamentos foram avaliados nas ninfas sobreviventes, sendo estas agrupadas por tratamento, transferidas para recipientes PET tubulares e mantidas em sala climatizada (Temp. $25 \pm 1,5{ }^{\circ} \mathrm{C}$, UR $70 \pm 10 \%$ e Fotofase 11 h) quando então for am alimentadas com adultos de Drosophyla sp.. No primeiro ensaio, as avaliações foram feitas após 24 horas e 4, 6, 10, 13 e 15 dias dos tratamentos e no segundo ensaio, $24,48,72$ horas; $5,10,15$ e 18 dias após.

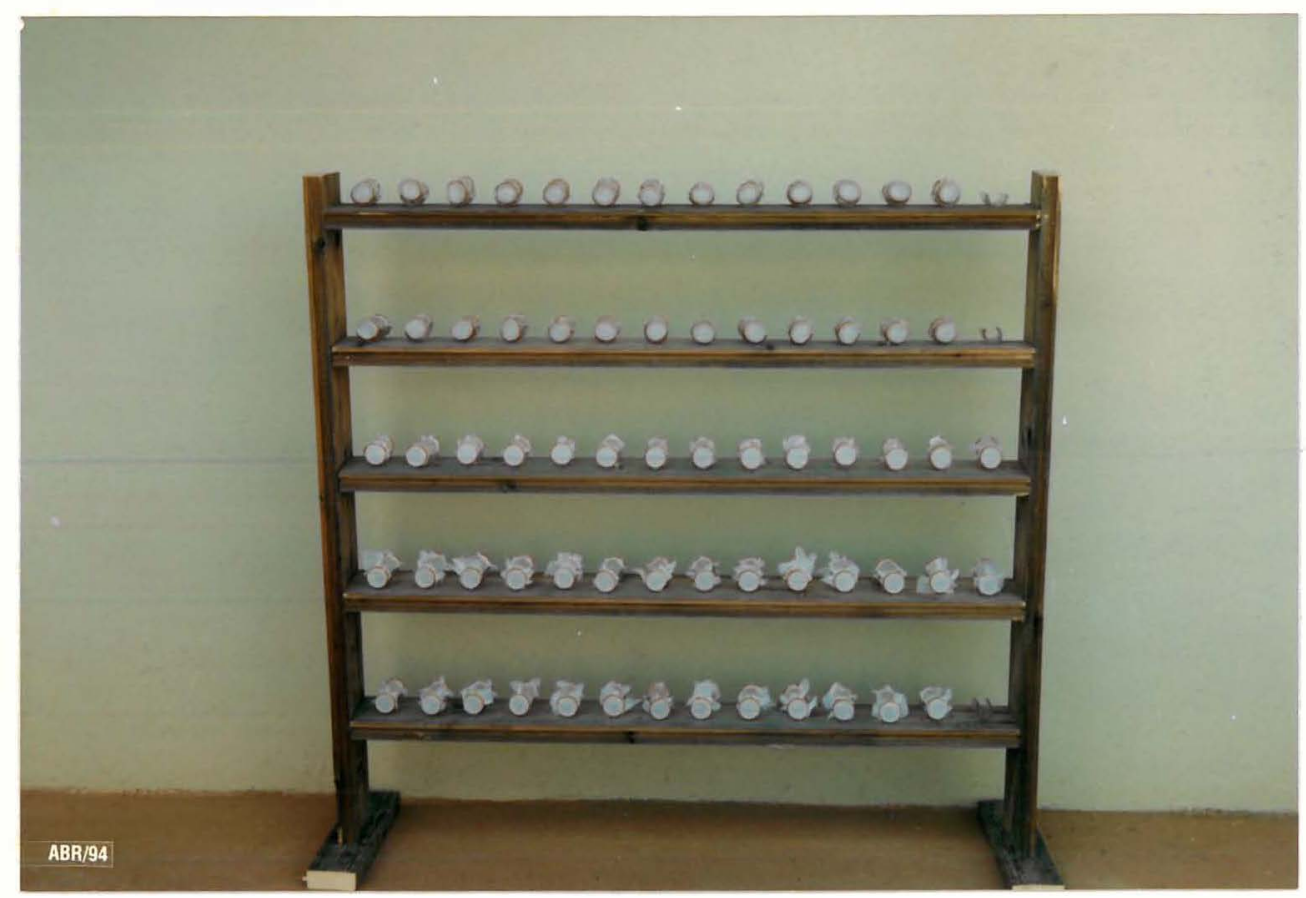

Figura 3. Vista geral do suporte de madeira contendo os tubos plásticos ou de vidro, utilizados nos testes de Imersão e Exposição a filme-seco. 


\subsubsection{Exposição a fi lme-seco}

Os acaricidas e dosagens do primeiro ensaio foram os mesmos dos testes de "Caminhamento sobre filme-seco" e "Imersão I" e o delineamento foi o de distribuição inteiramente casualizada, com sete tratamentos e cinco repetições.

Cada parcela constituiu-se de tubo de vidro de $7 \mathrm{~cm}$ de comprimento e aproximadamente $2,2 \mathrm{~cm}$ de diâmetro, fechado em ambas as extremidades com tela de "polyester", com as superfícies internas tratadas e contendo 2 ninfas de 20 instar.

Os tratamentos foram inicialmente feitos nos pedaços de "polyester", pela sua mergulhia nas respectivas caldas, após o que foram colocados a secar, à temperatura ambiente $\left(25^{\circ} \mathrm{C}\right)$, sobre armação de tela de "nylon", com ventilação. A seguir, trataram-se as paredes internas dos tubos de vidro: uma das extremidades foi vedada com filme de PVC preso com elástico, entornando-se a calda até $4 / 5$ do volume do tubo: a outra extremidade foi tapada com a palma da mão protegida por filme de PVC e então, revirando-se o tubo, molhou-se sua superfície. Após isto, o tubo foi esvaziado, colocado a escorrer e a secar sob venti lação à temperatura ambiente.

Após a secagem dos tubos, prenderam-se as telas nas extremidades e inseriram-se as aranhas, passandoos para suporte idêntico ao utilizado no teste de Imersão 
(Figura 3) e mantidos sob ventilação à temperatura de $24 \pm 2^{\circ} \mathrm{C}$.

As avaliações foram realizadas $24,48,72$ horas; 5,10 e 15 dias após a introdução das ninfas nos tubos. Após a primeira avaliação ( 24 horas) as aranhas sobreviventes foram agrupadas por tratamento, transferidas para recipientes PET e mantidas em sala climatizada, recebendo alimentação.

Conhecidos os resultados iniciais desse bioensaio, observou-se a ação residual do bifentrim, utilizando método semelhante ao descrito e realizando dois tratamentos (bifentrim e testemunha) e cinco repetições. Os tubos tratados foram colocados em duas vasilhas plásticas que foram vedadas e mantidas em sala climatizada (nas mesmas condições anteriormente descritas) por período de 13 dias. Transcorrido esse tempo, duas ninfas por parcela foram introduzidas nos tubos e estes colocados em suporte sob ventilação. A avaliação foi feita 20 horas após a introdução das aranhas. 


\section{RESUltados E discussão}

\subsection{Aranhas predominantes em citros}

Em Limeira foram coletados, em maio de 1990 (Limeira 1), 375 exemplares de aranha, dos quais 186 eram da família salticidae e, em dezembro do mesmo ano (Limeira 2), 159 exemplares, sendo 79 salticídeos. Isto correspondeu, respectivamente, à ocorrência de 49,60 e $49,68 \%$ de salticídeos (Tabela 2 ).

Em Artur Nogueira, 160 exemplares foram coletados, sendo 53 salticídeos, determinando uma ocorrência de $33,12 \%$ destes. (Tabela 2$)$.

Tabela 2. Ocorrência de salticídeos em Limeira e Artur Nogueira (SP) em 1990 e 1991.

\begin{tabular}{|c|c|c|c|}
\hline \multirow{2}{*}{ Locais } & \multicolumn{2}{|c|}{ No de exemplares de aranhas } & \multirow{2}{*}{$\begin{array}{c}\text { Porcentagem } \\
\text { de } \\
\text { Salticídeos }\end{array}$} \\
\hline & Total & Salticidae & \\
\hline Limeira 1 & 375 & 186 & 49,60 \\
\hline Limeira 2 & 159 & 79 & 49,68 \\
\hline Artur Nogueira & 160 & 53 & 33,12 \\
\hline Total & 694 & 318 & 45,82 \\
\hline
\end{tabular}


Aranhas da família Salticidae foram mais abundantes em Limeira e no total dos dois municípios, cuja ocorrência foi de $45,82 \%$ dos exemplares coletados.

Desta forma, a familia Salticidae foi a escolhida para o estudo, utilizando-se de uma de suas espécies.

\subsection{Desenvolvimento pós-embrionário de Euophrys sutrix}

Do casulo de postura coletado no campo, ocorreram duas emergências de ninfas durante 17 dias. Na primeira emergência, que durou 11 dias, surgiram 73 ninfas (61 no primeiro dia, 9 do quarto ao sexto dia e 3 no décimo primeiro dia); na segunda, que ocorreu 14 dias após o início da primeira ou três dias após o final desta, emergiram 41 ninfas num período de três dias, sendo 12 no primeiro dia e 29 no terceiro dia, totalizando 114 ninfas.

Observando-se o interior do casulo após a retirada das ninfas emergidas, constatou-se a presença de dois tipos de formas larvais, a maioria morta, designadas como pré-larva e larva por Vachon ${ }^{2}$, citado por FOELIX $(1982)$.

Conseqüentemente, seguindo a classificação de Vachon ${ }^{2}$ e as observações de HORNER \& STARKS (1972) para outra espécie de Salticidae, o início do desenvolvimento pós-embrionário de E. sutrix pode ser assim esquematizado: 
FASE LARVAL

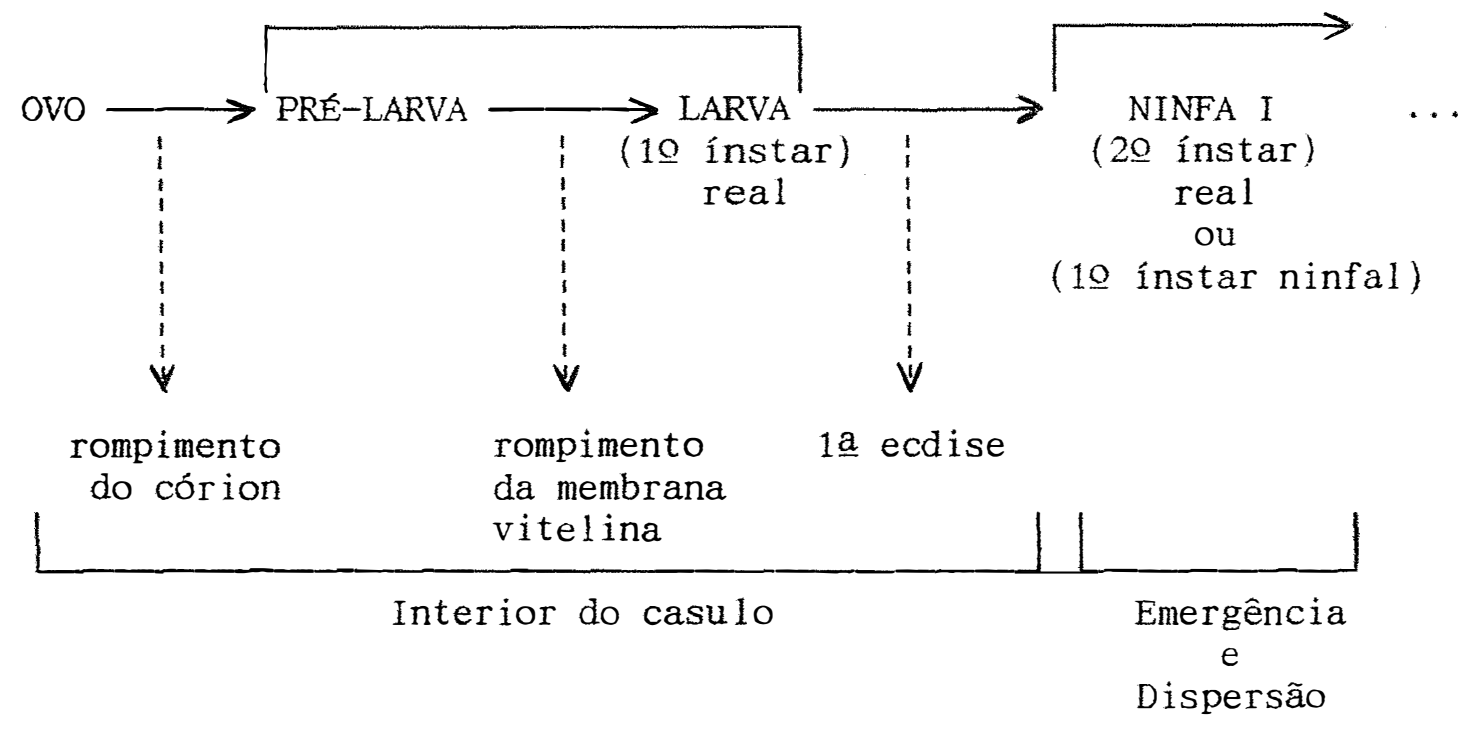

\subsubsection{Fase larval}

A fase larval iniciou-se com a pré-larva que era uma forma fixa, envolta por uma membrana, não apresentando semelhança com a larva ou a ninfa.

Essa fase desenvolveu-se no interior do casulo, o que impossibilitou a observação do seu desenvolvimento. Contudo, através do material encontrado, presumiu-se ter ocorrido somente uma pré-larva que, após o rompimento a membrana, originou a larva. FOELIX (1982) citou que para algumas espécies de aranhas podem ocorrer duas etapas de pré-larva antes de surgirem as larvas. Entretanto, as características observadas por HORNER \& STARKS (1972) para Metaphidippus galathea (Walck.) foram bastante semelhantes às observadas para a espécie estudada, isto é, ocorrência de uma pré-larva confinada pela membrana 
vitelina, distinguindo-se o cefalotórax com pernas, quelíceras e palpos.

As larvas de E. sutrix apresentaram coloração geral clara, com cefalotórax esbranquiçado, olhos frontais pouco definidos e abdome amarelo-claro. Tiveram pernas funcionais e, com raras exceções, permaneceram no interior do casulo. Podem ser consideradas como o primeiro ínstar do estágio jovem, diferenciando-se das ninfas I, principalmente pela pequena mobilidade, por não se alimentarem de presas e por não tecerem. Essas características também foram observadas por CRANE (1948) para Corythalia spp.. HORNER \& STARKS (1972) obtiveram que as larvas de $M$. galathea moviam-se no interior do ovissaco.

\subsubsection{Fase ninfal}

Após a ecdise das larvas, no interior do casulo, teve inicio a fase ninfal. A seguir, ocorreu a emergência das ninfas, não se obtendo dados do tempo decorrido entre esses eventos.

A fase ninfal iniciou-se no 2 o instar ou 1Q ínstar ninfal, designando-se as ninfas desse ínstar como "ninfas I", após o que ocorreu a $2 \underline{a}$ ecdise ou $1 \underline{a}$ ecdise ninfal originando as "ninfas II" (na descrição dos eventos. utilizaram-se os termos "instar ninfal" e "ecdise ninfal"). 
4.2.2.1. Características e Comportamentogeral das ninf as

Na natureza, os salticídeos, ao emergirem do casulo, iniciam a dispersão pelo ambiente. Contudo, no laboratório isto raramente ocorreu, havendo um acúmulo de individuos em volta e nas proximidades do casulo.

\subsection{Coloração (caracteres)}

As ninfas emergentes (ninfas I) apresentaram coloração geral creme-clara, não se distingüindo caracteres no corpo; posteriormente, no mesmo ínstar, o abdome tornou-se 1 igeiramente esverdeado em alguns individuos enquanto que outros apresentavam-no castanho e mais volumoso. Esta última característica foi bastante evidenciada no 2 o ínstar ninfal (ninfa II), quando começaram a surgir os caracteres típicos da espécie, na face dorsal do corpo. Nesta época, o abdome esverdeado de algumas das ninfas, passou para alaranjado, nada se concluindo a respeito dessas diferenças.

No 30 ínstar ninfal (ninfa III) os caracteres corpóreos dorsais se ampliaram e sua coloração tornou-se mais acentuada, surgindo, na face dorsal do abdome de muitos dos individuos, pequena risca preta-pálida, centro-longitudinal que, nos instares seguintes escureceu e se ampliou para uma faixa que tomou cerca de $1 / 3$ da área do 
abdome.

\subsection{Casulos-de-abrigo}

Logo após a passagem das ninfas emergentes para os recipientes de criação, o que se destacou foi sua agilidade, desde logo caçando as presas, produzindo fios de seda e confeccionando seus casulinhos-de-abrigo.

Pelo fato das ninfas apresentarem a tendência de permanecerem nos pontos mais altos, os abrigos foram construídos nas beiradas do topo dos recipientes. O ângulo formado pelas paredes laterais e pela tela foi utilizado para fixação dos fios, de maneira que os casulinhos localizaram-se na circuferência superior dos recipientes. Entretanto, em ínstares posteriores a lgumas das ninfas construíram-no na circunferência inferior, junto ao tampão, constatando-se, porém, que essas ninfas encontravamse com problemas de locomoção, não conseguindo galgar as paredes dos recipientes para chegarem ao topo. Estes abrigos foram sempre prejudicados, devido à necessidade de se retirar o tampão para realizar limpeza do recipiente.

Nos recipientes tubulares que continham várias ninfas, os abrigos foram, no início, construídos muito próximos, quase juntos e, algumas vezes, sobrepostos, mesmo havendo espaço suficiente para que fossem construídos mais separadamente. Mesmo com essa proximidade, houve convivência harmoniosa, não ocorrendo luta entre os 
indivíduos e nem canibalismo (Corythalia spp. também não apresentaram canibalismo, segundo CRANE, 1948); quando a lguma das ninfas "errava" de abrigo e entrava em outro, a "proprietária" a expulsava e, em não encontrando o seu abrigo, passava a construir outro.

Todos os casulos-de-abrigo tiveram formato tubular até o quinto ou sexto ínstar ninfal, tendo duas aberturas nas extremidades opostas. Porém, algumas das ninfas, a partir do sexto ou sétimo instar ninfal, os modificaram, passando a terem formato triangular, com mais uma abertura, afunilada para baixo. Esta nova abertura passou a ser a mais utilizada nas atividades diárias, ficando as duas superiores como "portas de fuga", isto é, quando perturbada, a ninfa escapava por uma das aberturas superiores.

Nos recipientes com gargalo, os abrigos foram construídos no tubo do gargalo que, com o tempo, foi totalmente preenchido com fios de seda, impossibilitando as observações interiores.

\subsubsection{Presas e Predação (Alimentação)}

As ninfas, assim como os adultos, somente atacaram presas móveis, observando-se que, quando a presa fornecida tinha pequena mobilidade, a aranha tardava a detectá-la, dirigindo-se a ela apenas ao perceber algum movimento. KASTON \& KASTON (1953) citaram que a aranha é 
atraída pelo movimento da presa.

Nos recipientes de criação não ocorreu a atividade de caça, tal qual na natureza, pois as presas encontravam-se confinadas e as aranhas somente esperavam o melhor momento para saltarem sobre as mesmas. O ataque geralmente ocorreu pela retaguarda e, para isto, a aranha circundava vagarosamente a presa até encontrar a posição ideal. Quando a aranha encontrava-se com muita fome, saltava de imediato logo ao perceber a presa, em qualquer posição e por isso, muitas vezes, não conseguia capturá-la. Ao saltar, emitia um fio-de-seda, fixado ao local onde se encontrava, ficando, às vezes, por ele suspensa, impedindo sua queda.

A presa capturada era imediatamente imobilizada e "sugada" no próprio local de captura ou transportada para o abrigo ou proximidades. KASTON \& KASTON (1953) citaram que as aranhas ingerem o alimento ou através de perfuração do corpo e injeção de líquido digestivo ou amassando o corpo e regurgitando sobre ele os fluidos digestivos, succionando os tecidos liqüefeitos, deixando somente os elementos quitinosos, não digeríveis. Para a espécie E. sutrix, a alimentação ocorreu, notadamente, da primeira forma, pois os cadáveres encontravam-se inteiros após serem abandonados pelas aranhas. Entretanto, foram encontrados alguns totalmente amassados ou destroçados, indicando que não foi uma constante a forma de alimentação da espécie. Esta última maneira de se alimentar, ocorreu, eventualmente, para as ninfas coletadas no campo, quando 
encontravam-se com muita fome.

Das presas fornecidas inicialmente, houve boa aceitação de dípteros, cigarrinhas e pequenos ortópteros e lepidópteros, não aceitação de adultos de Cycloneda sanguinea e repelência a formigas. Adultos de Chrysopa sp. e de Diabrotica speciosa (Germar) foram aceitos somente da primeira vez, após o que foram recusados, indicando que reconheciam as presas desfavoráveis.

Os insetos saltadores (cigarrinhas e ortópteros) e os lepidópteros foram descartados para a a limentação das aranhas. Os primeiros por causarem danos nos abrigos e perturbação das ninfas e os segundos por deixarem os recipientes impregnados de escamas.

Ceratitis capitata, apesar de ser bem aceita para alimentação, foi pouco fornecida devido à sua pequena mobilidade e à dificuldade encontrada para sua introdução nos recipientes.

Devido à importância da movimentação da presa na sua captura, sempre que possível manteve-se mais de um inseto nos recipientes, mesmo que o consumo médio diário das aranhas (Tabelas 3 e 4) fosse menor. No caso da introdução de $C$. capitata, a sua predação foi aumentada quando se introduziu, juntamente, um adulto de $M$. domestica, fazendo com que a mosca-do-mediterrâneo se tornasse mais ativa. Quando isto foi realizado, observou-se que as ninfas "criadas no laboratório", deram preferência à moscadoméstica, enquanto que as ninfas "coletadas no campo" 
predaram igualmente as duas espécies. Porém, 25 dias após o início dessa dieta, as "ninfas de campo" passarama preferir M. domestica.

Drosophyla sp. foi muito bem aceita pelas ninfas. HORNER \& STARKS (1972) e GONZALEZ \& ESTÉVEZ (1988) também utilizaram essa dieta em seus estudos com aranhas.

O consumo de Drosophyla sp. por ninfas I de E. sutrix é apresentada na Tabela 3 , onde nota-se que, a cada dia, a predação não foi constante e sim alternada, havendo ninfas que se alimentaram n'um dia, não se alimentando n'outro e ninfas que agiram ao contrário, resultando em coeficiente de variação alto. O consumo médio em seis observações durante período de oito dias, foi de 0,55 mosca/ninfa I/dia, ocorrendo, em média, predação mínima de 0,15 mosca/ninfa I e máxima de 1,15 mosca/ninfa I, em um dos dias do período observado, não se evidenciando aumento de consumo no transcorrer do ínstar.

Por sua vez, $M$. domestica, a lém de ser muito bem aceita por E. sutrix, foj de fácil manipulação. Esta presa também foi utilizada para alimentação de aranhas, por GONZALEZ E ESTÉVEZ (1988). 
Tabela 3. Consumo médio diário de Drosophyla sp., em seis observações durante oit• dias, por ninfas I de Euophrys sutrix. Temp. $25 \pm, 15^{\circ} \mathrm{C}$, UR $70 \pm 10 \%$ e Fotofase 11-14 horas.

\begin{tabular}{|c|c|c|c|c|}
\hline \multirow{2}{*}{\multicolumn{2}{|c|}{$\begin{array}{c}\text { Dias } \\
\text { Observados }\end{array}$}} & \multicolumn{3}{|c|}{ Número de moscas consumidas, por dia, por ninfa } \\
\hline & & $\bar{x} \pm s(\bar{x})$ & Interv.Variação & Coefic.Variação \\
\hline & $1 \underline{0}$ & $0,31 \pm 0,10$ & $0,00-0,60$ & 73,21 \\
\hline & 30 & $0,61 \pm 0,11$ & $0,30-1,20$ & 60,38 \\
\hline & $4 \underline{0}$ & $0,45 \pm 0,11$ & $0,00-1,10$ & 81,26 \\
\hline & $6 \underline{0}$ & $0,61 \pm 0,12$ & $0,00-1,36$ & 65,01 \\
\hline & $7 \underline{0}$ & $0,15 \pm 0,05$ & $0,00-0,33$ & 85,79 \\
\hline & 80 & $1,15 \pm 0,30$ & $0,25-2,00$ & 58,74 \\
\hline 10 & ao 80 & $0,55 \pm 0,14$ & $0,15-1,15$ & 63,14 \\
\hline
\end{tabular}

o consumo de mosca-doméstica por aranhas de último instar ninfal, em sete observações durante um período de 18 dias (Tabela 4), foi em média de 0,90 mosca/ninfa/ dia, que, guardando-se a proporcionalidade de tamanhos de ninfas e de presas, quase atingiu o dobro de consumo das ninfas I. Tal como para estas, o consumo médio diário flutuou e variou de 0,33 a 1,33 moscas/ninfa, mas o coeficiente de variação foi menor, devido à menor diferença de predação entre os individuos, em cada dia. Também neste caso, não ocorreu aumento de consumo no transcorrer do instar. 
Tabela 4. Consumo médio diário de Musca domestica, em sete observações durante 18 dias, por ninfas de último instar de Euophrys sutrix. Temp. $25 \pm 1,5^{\circ} \mathrm{C}$, UR $70 \pm 10 \%$ e Fotofase $11-14$ horas.

\begin{tabular}{cccc}
\hline \multirow{2}{*}{$\begin{array}{c}\text { Dias } \\
\text { Observados }\end{array}$} & \multicolumn{2}{c}{ Número de moscas consumidas, por dia, por ninfa } \\
\cline { 2 - 4 } & $\bar{x} \pm \mathrm{s}(\overline{\mathrm{x}})$ & Interv.Variação & Coefic.Variação \\
\hline 10 & $0,33 \pm 0,33$ & $0,00-1,00$ & - \\
$3 \underline{0}$ & $1,17 \pm 0,17$ & $1,00-1,50$ & 24,74 \\
$5 \underline{0}$ & $1,33 \pm 0,33$ & $1,00-2,00$ & 43,30 \\
$8 \underline{0}$ & $0,56 \pm 0,11$ & $0,33-0,67$ & 35,26 \\
11 & $1,00 \pm 0,39$ & $0,33-1,00$ & 67,00 \\
140 & $0,89 \pm 0,29$ & $0,33-1,33$ & 57,47 \\
180 & $1,00 \pm 0,25$ & $0,75-1,25$ & 35,36 \\
10 a 0 & $0,90 \pm 0,13$ & $0,33-1,33$ & 38,58 \\
\hline
\end{tabular}

\subsubsection{Atividade}

No desenvolvimento, ocorreram etapas em que, geralmente, as ninfas permaneceram em repouso total nos abrigos, não se alimentando e aguardando a ocorrência da ecdise. Após esta, ficaram ainda algum tempo abrigadas, quando então, saíram do casulo de abrigo para as atividades normais de busca de alimento. Estas etapas foram, respectivamente, designadas como "período inativo" ou "inatividade", "reinicio de atividade" e "período ativo" ou "atividade". o periodo inativo foi subdividido em "inatividade pré" e "inatividade pós" - ecdise e o período ativo correspondeu ao "ínstar ativo". Desta forma, os 
períodos inativo pós-ecdise, ativo e inativo pré-ecdise, nessa ordem, definiram o ínstar propriamente dito. Neste caso, entretanto, como os períodos inativos, no geral, desenvolveram-se no interior do abrigo, considerou-se como de maior importância o ínstar ativo. Isto porque, seria nesta época, na natureza, que as ninfas se encontrariam em atividade predatória e também mais expostas às adversidades do ambiente.

\subsection{Período inativo}

o primeiro período inativo ninfal provavelmente ocorreu após a ecdise das larvas, no interior do casulo-mãe.

Após a emergência das ninfas (início da atividade) estas tiveram, no máximo, oito periodos inativos ou seja, oito ecdises.

\subsection{Inatividade pré-ecdise}

O período de inatividade que precedeu a ecdise ficou bem definido para todas as ninfas até o $3 \underline{0}$ instar. Após este, algumas não permaneceram totalmente inativas, observando-se que saíam dos abrigos em busca de alimento. retornando em seguida. Supôs-se que isto aconteceu, por não se encontrarem suficientemente nutridas para permanecerem em repouso por periodo mais longo: até a 
ocorrência da ecdise.

O período médio de inatividade pré-ecdise em cada ínstar (Tabela 5) foi aumentando gradualmente, em patamares, tendo sido, do 10 ao 30 ínstar, próximo a 7 dias; no 40 e 5 o ínstares, próximo a 9 dias e, do 60 ao 8 o ínstar, cerca de 12 dias, resultando numa média geral de 9,4 dias inativos. Este período superou ao da espécie $M$. galathea, cujas ninfas ficaram inativas por 1 a 2 dias antes da ecdise (HORNER \& STARKS, 1972 ).

Tabela 5. Período médio de inatividade pré-ecdise nos ínstares ninfais de Euophrys sutrix. Temp. $25 \pm 1,5^{\circ}$ C, UR $70 \pm 10 \%$ e Fot of ase 11-14 horas.

\begin{tabular}{cccc}
\hline \multirow{2}{*}{ Instar } & \multicolumn{2}{c}{ Número de dias inativos pré-ecdise } \\
\cline { 2 - 4 } Ninfa & $\overline{\mathrm{x}} \pm \mathrm{s}(\overline{\mathrm{x}})$ & Interv.Variação & Coefic.Variação \\
\hline $1 \underline{0}$ & $6,80 \pm 0,29$ & $2-13$ & 36,96 \\
$2 \underline{0}$ & $7,30 \pm 0,24$ & $3-17$ & 32,17 \\
$3 \underline{0}$ & $6,83 \pm 0,30$ & $1-17$ & 42,84 \\
$4 \underline{0}$ & $8,92 \pm 0,48$ & $1-21$ & 46,24 \\
$5 \underline{0}$ & $8,90 \pm 0,39$ & $7-16$ & 33,30 \\
$6 \underline{0}$ & $11,33 \pm 0,41$ & $8-17$ & 20,26 \\
$7 \underline{0}$ & $12,94 \pm 0,61$ & $6-18$ & 19,91 \\
$8 \underline{0}$ & $11,83 \pm 1,25$ & & 25,86 \\
\hline
\end{tabular}

Pelo intervalo de variação (Tabela 5), pode-se observar que, até o 50 instar, os individuos apresentaram, no mínimo, de 1 a 3 dias de inatividade, passando para 6 a 8 dias nos três últimos instares. 0 
período máximo individual foi menor no 10 ínstar, não existindo grandes variações entre os demais ínstares.

\subsection{Ecdise}

A ecdise iniciou-se pela separação do cefalotórax e posteriormente houve a liberação das pernas e do abdome. HORNER \& STARKS (1972) descreveram o processo da troca-de-pele de $M$. galathea, registrando que o tempo necessário para isto foi de 10 minutos nos primeiros ínstares e de 20 a 30 min nos últimos.

A primeira ecdise de E. sutrix ocorreu, em média, cerca de 18 dias após a emergência das ninfas e a última, 205 dias ou quase 7 meses após (Tabela 6), observando-se que os intervalos das ecdises, em média, foram crescentes, com duração aproximada de $19,23,24,27,29,33$ e 38 dias, sucessivamente, da primeira para a última ecdise (Tabela ?). Essa característica diferiu da espécie $M$. galathea, estudada por HORNER \& STARKS (1972), cujos intervalos de ecdise tiveram duração decrescente. 
Tabela 6. Idade média, em dias, desde a emergência das ninfas do casulo-mãe, para ocorrência das ecdises de Euophrys sutrix. Temp. $25 \pm 1,5^{\circ} \mathrm{C}$, UR $70 \pm 10 \%$ e Fotofase 11- 14 horas.

\begin{tabular}{cccr}
\hline & \multicolumn{3}{c}{ Idade (dias) } \\
\cline { 2 - 4 } Ninfa & $\bar{x} \pm s(\bar{x})$ & Interv.Variação & Coefic.Variação \\
\hline $1 \underline{a}$ & $18,22 \pm 0,29$ & $14-31$ & 15,65 \\
$2 \underline{a}$ & $37,33 \pm 0,44$ & $24-55$ & 11,42 \\
$3 \underline{a}$ & $61,35 \pm 0,58$ & $51-74$ & 9,44 \\
$4 \underline{a}$ & $86,00 \pm 1,02$ & $69-123$ & 11,13 \\
$5 \underline{a}$ & $113,76 \pm 1,65$ & $96-148$ & 11,02 \\
$6 \underline{a}$ & $142,03 \pm 2,06$ & $123-181$ & 8,59 \\
$7 \underline{a}$ & $176,44 \pm 4,29$ & $154-216$ & 10,33 \\
$8 \underline{a}$ & $205,14 \pm 5,28$ & $187-223$ & 6,81 \\
\hline
\end{tabular}

Tabela 7. Duração média, em dias, dos intervalos das ecdises de Euophrys sutrix. Temp. $25 \pm 1,5^{\circ} \mathrm{C}$, UR $70 \pm 10 \%$ e Fotofase 11-14 horas.

\begin{tabular}{lccc}
\hline & \multicolumn{4}{c}{ Duração (dias) } \\
\cline { 2 - 4 } Intervalo Ecdises & $\bar{x} \pm s(\bar{x})$ & Interv.Variação & Coefic.Variação \\
\hline $1 \underline{a} \rightarrow 2 \underline{a}$ & $19,53 \pm 0,34$ & $12-26$ & 14,66 \\
$2 \underline{a} \rightarrow 3 \underline{a}$ & $23,01 \pm 0,53$ & $14-38$ & 21,92 \\
$3 \underline{a} \rightarrow 4 \underline{a}$ & $24,11 \pm 0,68$ & $8-47$ & 25,74 \\
$4 \underline{a} \rightarrow 5 \underline{a}$ & $26,64 \pm 0,76$ & $11-38$ & 21,66 \\
$5 \underline{a} \rightarrow 6 \underline{a}$ & $29,35 \pm 1,20$ & $21-51$ & 23,84 \\
$6 \underline{a} \rightarrow 7 \underline{a}$ & $33,47 \pm 2,00$ & $22-49$ & 24,68 \\
$7 \underline{a} \rightarrow 8 \underline{a}$ & $38,14 \pm 4,39$ & $27-56$ & 30,48 \\
\hline
\end{tabular}

Ocorreram a lgumas variações, que não for am consideradas nas médias, tanto nas idades para ecdise como 
nos seus intervalos, havendo, por exemplo, uma ninfa que teve a $6 \underline{a}$ ecdise aos 261 dias, com intervalo de 119 dias da $5 \underline{a}$ para $6 \underline{a}$ ecdise e outra cuja $7 \underline{a}$ ecdise ocorreu aos 260 dias, num intervalo de 79 dias de duração da $6 \underline{a}$ para a $7 \underline{a}$ ecdise. Nesses dois casos, estas foram as últimas ecdises, quando então os indivíduos tornaram-se adultos machos.

Considerando-se somente as ninfas que chegaram à fase adulta, as médias de idade para ocorrência das ecdises de machos e fêmeas criadas no laboratório (Tabela 8) tiveram pequena diferença entre os sexos, tendo os machos trocado de pele cerca de 4 dias antes das fêmeas, até a $2 \underline{a}$ ecdise; da $3 \underline{a}$ à $6 \underline{a}$ ecdise e, notadamente, da $4 \underline{a}$ à 6â, houve inversão, as fêmeas trocando até 7 dias antes dos machos. Porém, nas duas últimas ecdises as idades praticamente se igualaram. Em relação à duração dos intervalos de ecdise dos sexos ninfais (Tabela 9), observouse que, no geral, houve diferença para machos e fêmeas. exceto da $1 \underline{a}$ para a $2 \underline{a}$ e da $4 \underline{a}$ para a $5 \underline{a}$ ecdise. Entretanto, tal como nas idades para ecdises (Tabela 8), as diferenças médias dos intervalos, observadas para um dos sexos, não foram constantemente maiores ou menores que para o outro, visto que os machos apresentaram maior intervalo de tempo da 2a à $4 \underline{a}$ ecdise e da $5 \underline{a}$ para a $6 \underline{a}$ ecdise, invertendo-se da $6 \underline{a}$ a 8a ecdise, quando as fêmeas tiveram intervalos de maior duração . 
Tabela 8. Idades médias, em dias, para ocorrência das ecdises de ninfas machos (M) e fêmeas (F) de Euophrys sutrix. Temp. $25 \pm 1,5^{\circ} \mathrm{C}$, UR $70 \pm 10 \%$ e Fotofase

$11-14$ horas.

\begin{tabular}{|c|c|c|c|c|c|c|}
\hline \multirow{3}{*}{$\begin{array}{l}\text { Ecdise } \\
\text { Ninfal }\end{array}$} & \multicolumn{6}{|c|}{ Idade (dias) } \\
\hline & \multicolumn{2}{|c|}{$\bar{x} \pm s(\bar{x})$} & \multicolumn{2}{|c|}{ Interv . Variação } & \multicolumn{2}{|c|}{ Coefic.Variação } \\
\hline & $M$ & $F$ & M & $\mathrm{F}$ & $M$ & $\mathrm{~F}$ \\
\hline $1 \underline{a}$ & $17,14 \pm 0,70$ & $21,33 \pm 4,84$ & $15-20$ & $16-31$ & 10,88 & 39,31 \\
\hline $2 \underline{a}$ & $37,37 \pm 0,96$ & $41,00 \pm 4,78$ & $34-42$ & $34-55$ & 7,28 & 23,31 \\
\hline $3 \mathrm{a}$ & $63,22 \pm 1,98$ & $61,00 \pm 4,81$ & $54-74$ & $51-73$ & 9,42 & 15,78 \\
\hline $4 \underline{a}$ & $90,67 \pm 4,10$ & $83,25 \pm 12,97$ & $76-111$ & $69-97$ & 13,58 & 15,58 \\
\hline $5 \underline{a}$ & $119,75 \pm 5,66$ & $113,75 \pm 6,90$ & $101-142$ & $99-126$ & 13,37 & 12,13 \\
\hline $6 \mathrm{a}$ & $146,37 \pm 5,53$ & $141,00 \pm 5,45$ & $133-181$ & $126-150$ & 10,68 & 7,73 \\
\hline $7 \underline{a}$ & $173,14 \pm 4,72$ & $175,00 \pm 10,16$ & $159-191$ & $154-197$ & 12,48 & 11,61 \\
\hline $8 \mathrm{a}$ & $205,60 \pm 7,40$ & $204,00 \pm 6,00$ & $187-223$ & $198-223$ & 4,16 & 6,81 \\
\hline
\end{tabular}

Tabela 9. Duração média, em dias, dos intervalos das ecdises de ninfas machos (M) e fêmeas (F) de Euophrys sutrix. Temp. $25 \pm 1,5^{\circ} \mathrm{C}, \quad$ UR $70 \pm 10 \%$ e Fotofase 11-14 horas.

\begin{tabular}{|c|c|c|c|c|c|c|}
\hline \multirow{3}{*}{$\begin{array}{l}\text { Intervalo } \\
\text { de } \\
\text { Ecdises }\end{array}$} & \multicolumn{6}{|c|}{ Duração (dias) } \\
\hline & \multicolumn{2}{|c|}{$\bar{x} \pm s(\bar{x})$} & \multicolumn{2}{|c|}{ Interv.Variação } & \multicolumn{2}{|c|}{ Coefic. Variação } \\
\hline & $M$ & $\mathrm{~F}$ & M & $\mathrm{F}$ & M & $\mathrm{F}$ \\
\hline $1 \underline{\mathrm{a}} \rightarrow 2 \underline{\mathrm{a}}$ & $19,57 \pm 1,04$ & $20,33 \pm 1,86$ & $14-22$ & $18-24$ & 14,10 & 15,81 \\
\hline $2 \underline{a} \rightarrow 3 \underline{a}$ & $26,25 \pm 2,26$ & $20,00 \pm 2,68$ & $20-38$ & $17-28$ & 24,33 & 26,77 \\
\hline $3 \underline{a} \rightarrow 4 \underline{a}$ & $27,44 \pm 2,91$ & $22,25 \pm 2,02$ & $19-44$ & $18-27$ & 31,82 & 18,12 \\
\hline $4 \underline{a} \rightarrow 5 \underline{a}$ & $30,37 \pm 2,21$ & $30,50 \pm 1,19$ & $21-38$ & $29-34$ & 20,59 & 7,80 \\
\hline $5 \underline{a} \rightarrow 6 \underline{a}$ & $29,14 \pm 2,22$ & $26,50 \pm 2,90$ & $23-40$ & $22-35$ & 20,15 & 21.90 \\
\hline $6 \underline{a} \rightarrow 7 \underline{a}$ & $31,71 \pm 2,35$ & $34,75 \pm 5,66$ & $27-39$ & $22-49$ & 19,58 & 32,59 \\
\hline $7 \underline{a} \rightarrow 8 \underline{a}$ & $35,00 \pm 4,68$ & $46,00 \pm 10,00$ & $30-53$ & $36-56$ & 29,90 & 30,74 \\
\hline
\end{tabular}


As durações dos intervalos das últimas ecdises das ninfas coletadas no campo que chegaram à fase adulta (Tabela 10) diferiram daquelas obtidas para as ninfas criadas em laboratório. Em relação a estas, as ninfas de campo apresentaram, da antepenúltima para a penúltima ecdise, intervalo de tempo em média cerca de 8 dias menor e, da penúltima para a última ecdise, perto de 8 dias maior. Entre os sexos das ninfas coletadas no campo, os machos tiveram, em média, da penúltima para a última ecdise, intervalo de duração cerca de 20 dias menor que das fêmeas. As ninfas-macho de laboratório também apresentaram menor tempo que as fêmeas nesse intervalo de ecdises, que foi aproximadamente de 10 dias.

A ecdise constituiu-se de uma etapa crítica na vida de E. sutrix, pois foi quando ocorreu a maior mortalidade. Muitas das mortes foram, indiretamente, causadas pela dificuldade ou mesmo impossibilidade de liberação da exúvia e/ou das pernas (isso é discutido com detalhes no item 4.2.2.4).

HORNER \& STARKS (1972) também observaram alta mortalidade de $M$. galathea nessa época, citando que esses problemas poderiam advir da liberação prematura de ecdisônio. Contudo, para E. sutrix supôs-se que a origem dos problemas foi de ordem nutricional, causada pela dieta (presas) não diversificada. Isto, porque nenhuma das ninfas coletadas no campo morreu, pois elas puderam se alimentar de variadas espécies de presas, até a sua captura. 
Tabela 10. Duração média, em dias, dos intervalos das últimas ecdises das ninfas machos e fêmeas de Euophrys sutrix coletadas no campo. Temp. $25 \pm 1,5^{\circ} \mathrm{C}$, UR $70 \pm 10 \%$ e Fotofase 11-14 horas.

\begin{tabular}{|c|c|c|c|}
\hline \multirow{2}{*}{$\begin{array}{c}\text { Intervalo } \\
\text { de } \\
\text { Ecdises }\end{array}$} & \multicolumn{3}{|c|}{ Duração (dias) } \\
\hline & $\bar{x} \pm s(\bar{x})$ & Interv.Variação & Coefic.Variação \\
\hline \multicolumn{4}{|l|}{ Antep. $\rightarrow$ pen. } \\
\hline - Macho & $23,67 \pm 4,41$ & $17-32$ & 32,27 \\
\hline - Fêmea & $25,37 \pm 0,94$ & $23-31$ & 10,52 \\
\hline$-M+F$ & $24,91 \pm 1,25$ & $17-32$ & 16,69 \\
\hline \multicolumn{4}{|l|}{ Pen. $\rightarrow$ Últ. } \\
\hline - Macho & $33,89 \pm 2,72$ & $25-50$ & 24,08 \\
\hline - Fêmea & $54,20 \pm 3,99$ & $38-96$ & 28,51 \\
\hline$-M+F$ & $46,58 \pm 3,35$ & $25-96$ & 35,23 \\
\hline
\end{tabular}

(a) Antep. = antepenúltima

Pen. = penúlt ima

últ. = última

A morte de ninfas de E. sutrix nas ecdises teve início na 3â, prolongando-se até a 6a, tendo ocorrido morte de um adulto durante a $8 \underline{a}$ ecdise. Do total de ninfas mortas $72,84 \%$ ocorreram nas ecdises, sendo $1,23 \%$ na $3 \underline{a}$, $22,22 \%$ na $4 \underline{a}, 33,33 \%$ na $5 \underline{a}$ e $14,81 \%$ na $6 \underline{a}$ ecdise. 


\subsection{Inatividade pós-ecdise e Período} inativo total

Após a ecdise se completar, geralmente as ninfas permaneceram por algum tempo abrigadas, porém durante perío mais curto que o observado na inatividade préecdise. Algumas das ninfas emergiram dos abrigos logo após a ecdise e outras a inda neles permaneceram por até 18 dias. Mas, em média, o período inativo pós-ecdise variou de 3,10 a 5,24 dias, resultando numa média geral de 4,01 dias, observando-se também que esse período reduziu-se um pouco após o 60 ínstar (Tabela 11 ).

Espécies do gênero Corythalia, estudadas por CRANE (1948), passaram somente de 1 a pouco mais de 3 dias abrigadas, após as ecdises.

Tabela 11. Período médio de inatividade pós-ecdise nos instares ninfais de Euophrys sutrix. Temp. $25 \pm 1,5^{\circ} \mathrm{C}$, UR $70 \pm 10 \%$ e Fotofase $11-14$ horas.

\begin{tabular}{cccc}
\hline \multirow{2}{*}{ Instar } & \multicolumn{2}{c}{ Número de dias inativos pós-ecdise } \\
\cline { 2 - 4 } Ninfal & $\bar{x} \pm s(\bar{x})$ & Interv.Variação & Coefic.Variação \\
\hline 20 & $4,34 \pm 0,30$ & $0-11$ & 51,69 \\
30 & $5,24 \pm 0,32$ & $1-17$ & 53,32 \\
$4 \underline{0}$ & $4,06 \pm 0,26$ & $1-17$ & 59,55 \\
$5 \underline{0}$ & $4,94 \pm 0,42$ & $0-18$ & 71,52 \\
60 & $3,10 \pm 0,27$ & $1-7$ & 55,23 \\
$7 \underline{0}$ & $3,14 \pm 0,63$ & $1-13$ & 91,27 \\
80 & $3,25 \pm 0,46$ & $1-7$ & 49,31 \\
\hline
\end{tabular}


o período inativo total, que englobou inatividade pré-ecdise, ecdise e inatividade pós-ecdise, foi levemente maior a partir do entre-ínstares 60 e 70 (Tabela 12), em conseqüência do aumento do período inativo préecdise nessa época. Em média, o período inativo mínimo foi de 10,73 dias, no entre-ínstares 1 o e 20 e o máximo de 15,33 dias, no entre ínstares 70 e 80 , o que resultou em uma média de 12,72 dias inativos entre os instares ninfais.

Tabela 12. Período médio de inatividade entre os ínstares de Euophrys sutrix. Temp. $25 \pm 1,5^{\circ} \mathrm{C}$, UR $70 \pm 10 \%$ e Fotofase 11-14 horas.

\begin{tabular}{|c|c|c|c|}
\hline \multirow{2}{*}{$\begin{array}{c}\text { Entre } \\
\text { Instares }\end{array}$} & \multicolumn{3}{|c|}{ Número de dias inativos } \\
\hline & $\bar{x} \pm s(\bar{x})$ & Interv.Variação & Coefic.Variação \\
\hline $1 \underline{0}$ e $2 \underline{0}$ & $10,73 \pm 0,32$ & $4-18$ & 23,34 \\
\hline $2 \underline{0}$ e $3 \underline{0}$ & $12,51 \pm 0,37$ & $6-22$ & 25,98 \\
\hline 30 e $4 \underline{O}$ & $10,93 \pm 0,37$ & $3-23$ & 31,84 \\
\hline $4 \underline{O}$ e $5 \underline{O}$ & $14,00 \pm 0,59$ & $7-27$ & 33.45 \\
\hline $5 \underline{0}$ e $6 \underline{\underline{Q}}$ & $11,85 \pm 0,47$ & $6-18$ & 24,61 \\
\hline $6 \underline{0}$ e $7 \underline{0}$ & $14,81 \pm 0,62$ & $11-23$ & 19,05 \\
\hline $7 \underline{0}$ e $8 \underline{0}$ & $15,33 \pm 1,02$ & $10-23$ & 22,99 \\
\hline $8 \underline{0}$ e $9 \underline{o}^{(a)}$ & $15,00 \pm 0,71$ & $13-17$ & 10,54 \\
\hline
\end{tabular}

(a) O 90 ínstar correspondeu ao início da fase adulta.

\subsection{Período ativo}

As ninfas de E. sutrix tiveram, no máximo, 8 instares, tendo os machos de 6 a 8 ( 7 a 8 , mais 
freqüentemente) e as fêmeas 7 ou 8. CRANE (1948) obteve, através de medição das carapaças, que, em três espécies do gênero Corythalia, as ninfas machos apresentaram 6 ínstares e as fêmeas ? ínstares. Na espécie $M$. galathea, as ninfas tiveram até 6 instares, sendo 3 a 6 para machos e 5 ou 6 para fêmeas (HORNER \& STARKS, 1972).

Durante o período ativo, as ninfas criadas no laboratório permaneceram quase todo o tempo diurno fora do abrigo. Aquelas coletadas no campo, talvez por não se encontrarem adaptadas às condições laboratoriais, saíam à caça e logo retornavam ao abrigo, geralmente permanecendo próximas à sua saída.

o período ativo médio aumentou gradativamente a partir do 2 o ínstar, passando de 7,53 dias para 19,17 dias no último ínstar ninfal (Tabela 13). O 10 ínstar foi exceção, provavelmente devido às manipulações sofridas pelas ninfas na etapa inicial do estudo.

Pela Tabela 13, pode-se ainda observar que do $2 \underline{0}$ ao $5 \underline{0}$ ínstar ocorreram os menores números de dias ativos, que foram 2,3 e 4 dias, enquanto que do $6 \underline{0}$ ao $8 \underline{0}$ ínstar o período mínimo de atividade foi maior e variou de 7 a 14 dias. O período máximo de dias ativos, foi de 31 dias, no 6o ínstar, havendo, contudo, a lgumas exceções, que não foram computadas nas médias, ou seja, uma ninfa com 36 dias ativos no $4 \underline{Q}$ e $6 \underline{0}$ instares, uma com 53 dias e outra com 70 dias no 70 instar e duas com 37 e 38 dias ativos no $8 \underline{0}$ instar. 
Tabela 13. Período ativo médio dos ínstares ninfais de Euophrys sutrix. Temp. $25 \pm 1,5^{\circ} \mathrm{C}$, UR $70 \pm 10 \%$ e Fotofase 11-14 horas.

\begin{tabular}{cccc}
\hline \multirow{2}{*}{$\begin{array}{c}\text { Instar } \\
\text { Ninfal }\end{array}$} & $\overline{\mathrm{x}} \pm \mathrm{s}(\overline{\mathrm{x}})$ & Interv.Variação & Coefic.Variação \\
\cline { 2 - 4 } & $11,70 \pm 0,26$ & $6-18$ & 23,33 \\
$2 \underline{0}$ & $7,53 \pm 0,36$ & $2-15$ & 40,85 \\
$3 \underline{0}$ & $10,83 \pm 0,43$ & $2-24$ & 36,84 \\
$4 \underline{0}$ & $11,88 \pm 0,53$ & $4-27$ & 37,86 \\
$5 \underline{0}$ & $13,10 \pm 0,56$ & $3-23$ & 35,44 \\
$6 \underline{0}$ & $13,97 \pm 0,87$ & $7-26$ & 34,80 \\
$7 \underline{0}$ & $16,53 \pm 1,67$ & $8-31$ & 41,70 \\
$8 \underline{0}$ & $19,17 \pm 1,45$ & $14-25$ & 18,50 \\
\hline
\end{tabular}

Em média, o ínstar ativo (período ativo dos ínstares ninfais) durou 13,09 dias, totalizando 104,71 dias ativos na fase ninfal.

Considerando os períodos inativos pré e pós-ecdise, a duração total do instar foi de 26,5 dias, em média.

\subsection{Tamanho e Crescimento}

No início do 10 ínstar ativo, as ninfas

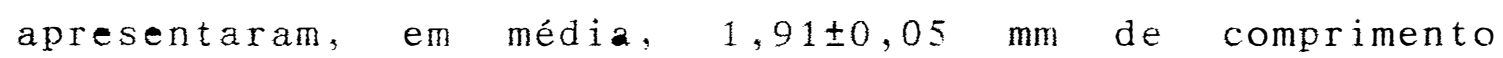
corporal.

o comprimento médio do corpo ao final de cada instar ativo é apresentado na Tabela 14, observando-se 
que houve um crescimento de aproximadamente $0,7 \mathrm{~mm}$ do 10 ao $2 \underline{0}$ e do $2 \underline{0}$ ao $3 \underline{0}$ instar; $1,0 \mathrm{~mm}$ do $3 \underline{0}$ ao $4 \underline{0}$ e do $4 \underline{0}$ ao $5 \underline{0}$ instar e de $1,3 \mathrm{~mm}$ em média, entre os demais instares, resultando em crescimento médio próximo de $1,1 \mathrm{~mm}$ por ínstar ativo. Desde o início do 10 instar até o final do último ativo, as ninfas tiveram o comprimento do corpo aumentado de aproximadamente $8,2 \mathrm{~mm}$.

Tabela 14. Comprimento médio do corpo ao final dos instares ativos das ninfas de Euophrys sutrix. Temp. $25 \pm 1,5^{\circ} \mathrm{C}$, UR $70 \pm 10 \%$ e Fotofase $11-14$ horas.

\begin{tabular}{cccc}
\hline \multirow{2}{*}{$\begin{array}{c}\text { Final do } \\
\text { Instar }\end{array} \bar{x} \pm \mathrm{s}(\bar{x})$} & Interv.Variação & Coefic.Variação \\
\cline { 2 - 4 } & $2,59 \pm 0,05$ & $2,1-3,0$ & 10,07 \\
$2 \underline{0}$ & $3,33 \pm 0,05$ & $2,6-4,0$ & 11,35 \\
$3 \underline{0}$ & $4,12 \pm 0,04$ & $3,0-5,0$ & 9,76 \\
$4 \underline{0}$ & $5,19 \pm 0,06$ & $3,7-6,7$ & 10,87 \\
$5 \underline{0}$ & $6,23 \pm 0,07$ & $4,8-7,2$ & 9,51 \\
$6 \underline{0}$ & $7,44 \pm 0,17$ & $5,6-9,0$ & 10,81 \\
$7 \underline{0}$ & $8,83 \pm 0,19$ & $7,5-10,2$ & 9,47 \\
$8 \underline{0}$ & $10,15 \pm 0,19$ & $9,5-11,0$ & 5,34 \\
\hline
\end{tabular}

Entre os sexos, constatou-se que, em média, as ninfas machos tiveram comprimento do corpo $0,5 \mathrm{~mm}$ maior que as ninfas fêmeas (Tabela 15) podendo-se, por isso, considerar que praticamente não houve diferença de tamanho entre os sexos ninfais. 
Tabela 15. Comprimento médio do corpo, ao final dos ínstares ativos de ninfas machos (M) e fêmeas (M) de Euophrys. sutrix. Temp. $25 \pm 1,5^{\circ} \mathrm{C}$, UR $70 \pm 10 \% \mathrm{e}$ Fotofase 11-14 horas.

\begin{tabular}{|c|c|c|c|c|c|c|}
\hline \multirow{3}{*}{$\begin{array}{l}\text { Final do } \\
\text { Instar }\end{array}$} & \multicolumn{6}{|c|}{ Comprimento do corpo das ninfas (mm) } \\
\hline & \multicolumn{2}{|c|}{$\bar{x} \pm s(\bar{x})$} & \multicolumn{2}{|c|}{ Interv . Variação } & \multicolumn{2}{|c|}{ Coefic.Variaçāo } \\
\hline & $M$ & F & M & $\mathrm{F}$ & M & F \\
\hline 20 & $3,30 \pm 0,20$ & $2,93 \pm 0,28$ & $2,9-3,8$ & $2,6-3,5$ & 13,89 & 16,82 \\
\hline 30 & $4,31 \pm 0,14$ & $3,87 \pm 0,15$ & $4,0-5,0$ & $3,5-4,2$ & 9,52 & 7.71 \\
\hline 40 & $5,56 \pm 0,27$ & $5,10 \pm 0,21$ & $4,5-6,5$ & $4,8-5,5$ & 13,96 & 7,07 \\
\hline 50 & $6,42 \pm 0,15$ & $5,57 \pm 0,30$ & $6,0-7,2$ & $5,0-6,0$ & 7,00 & 9,22 \\
\hline 60 & $7,70 \pm 0,21$ & $7,50 \pm 0,20$ & $7,0-9,0$ & $7,0-8,0$ & 8,29 & 5,44 \\
\hline 70 & $9,44 \pm 0,22$ & $8,67 \pm 0,51$ & $8,5-10,2$ & $7,5-10,0$ & 6,70 & 11,84 \\
\hline 80 & $10,34 \pm 0,27$ & $9,75 \pm 0,25$ & $9,5-11,0$ & $9,5-10,0$ & 5,75 & 3,63 \\
\hline
\end{tabular}

o tamanho de ninfas macho e fêmea, coletadas no campo, nos dois últimos ínstares (Tabela 16), também diferiu muito pouco entresi. Contudo, em geral essas ninfas foram um pouco menores que aquelas criadas no laboratório tendo, em média, respectivamente no penúltimo e último ínstar ativo, 1,6 e $0,7 \mathrm{~mm}$ a menos. 
Tabela 16. Comprimento médio do corpo nos últimos ínstares de ninfas machos e fêmeas de Euophrys sutrix, coletadas no campo. Temp. $25 \pm 1,5^{\circ} \mathrm{C}$, UR $70 \pm 10 \%$ e Fotofase 11-14 horas.

\begin{tabular}{|c|c|c|c|}
\hline \multirow{2}{*}{ Instares } & \multicolumn{3}{|c|}{ Comprimento do corpo das ninfas (mm) } \\
\hline & $\bar{x} \pm s(\bar{x})$ & Interv.Variação & Coefic.Variação \\
\hline \multicolumn{4}{|l|}{ Penúl timo } \\
\hline - Macho & $7,30 \pm 0,17$ & $7,0-7,6$ & 4,11 \\
\hline - Fêmea & $7,76 \pm 0,19$ & $7,0-8,5$ & 6,61 \\
\hline$-M+F$ & $7,62 \pm 0,16$ & $7,0-8,5$ & 6,48 \\
\hline \multicolumn{4}{|l|}{ Ult imo } \\
\hline - Macho & $9,23 \pm 0,33$ & $8,0-10,5$ & 8,74 \\
\hline - Fêmea & $9,43 \pm 0,43$ & $8,0-11,0$ & 11,23 \\
\hline$-M+F$ & $9,33 \pm 0,26$ & $8,0-11,0$ & 9,68 \\
\hline
\end{tabular}

\subsubsection{Mortalidade}

Ocorreram problemas na troca de pele que consistiram da não liberação da exúvia e aprisionamento de pernas podendo ter como conseqüencia sua perda total, designada como autotomia das pernas. Segundo FOELIX (1982), a autotomia pode ser praticada não somente durante a ecdise, quando uma extremidade não é liberada, mas também como defesa contra um agressor, sob condições naturais.

Nas ecdises iniciais de E. sutrix, a cápsula cefalotorácica se desprendeu independentemente da liberaça do restante da exúvia. Em alguns casos, as ninfas saíram do abrigo com esse resto de exúvia preso ou no 
terminal do abdome ou na região das pernas. Neste caso, o esforço para a liberação das pernas, muitas vezes causou a morte da ninfa. Isto também foi observado para $M$. galathea POr HORNER \& STARKS (1972).

A exúvia presa no terminal do abdome, acabou por se soltar durante o ínstar mas, antes disso, dificultou a alimentação e estressou as ninfas, que geralmente morreram no ínstar seguinte.

Quando o resto de exúvia ficou preso na região das pernas, dificilmente desprendeu-se sem causar a perda parcial (com dano e não funcional) ou total (amputação) de uma ou mais pernas, ocasionando, no mesmo ínstar, dificuldade de alimentação (captura de presas) e de l o comoção.

As pernas perdidas podem ser regeneradas. FOELIX (1982) relatou que a reposição pode ocorrer na próxima ecdise, dependendo da época da amputação, sendo a perna regenerada mais curta que a original e com menor número de pêlos sensoriais, que são lentamente suplementados no decorrer das ecdises.

Para E. sutrix a perda de pernas, parcial ou total, foi observada da $4 \underline{a}$ ecdise ao $7 \underline{0}$ ínstar, com regeneração de somente 1 perna amputada ou 3 danificadas, quando os problemas ocorreram até o 50 instar, em cerca de 33\% dos casos. Os demais casos resultaram, com raras exceços, em morte na ecdise ou no instar seguinte. Uma das ninfas, após ter perdido uma perna no 50 instar, sobreviveu 
até a 8ạ ecdise, quando morreu entrando na fase adulta; outra, que teve uma perna amputada no 70 instar, tornou-se adulto com 7 pernas, com vida normal e produzindo descendentes (Tabela 17).

As pernas regeneradas foram mais curtas que as originais e de coloração mais clara, isto devido provavelmente à presença de menor número de pêlos sensoriais, conforme relato de FOELIX (1982).

Tabela 17. Perda de pernas de ninfas de Euophrys sutrix nos ínstares e suas conseqüências. Temp. $25 \pm 1,5^{\circ} \mathrm{C}$, UR $70 \pm 10 \%$ e Fotofase 11-14 horas.

\begin{tabular}{|c|c|c|c|c|}
\hline $\begin{array}{l}\text { Número } \\
\text { de Ninfas }\end{array}$ & $\begin{array}{l}\text { Número de } \\
\text { e } \mathrm{T} \text { i po }\end{array}$ & $\begin{array}{l}\text { Pernas Perdidas } \\
\text { de Perda }\end{array}$ & $\begin{array}{l}\text { Instar da } \\
\text { Observação }\end{array}$ & Conseqüências \\
\hline 1 & $3 ; 1$ & parcial & 50 & Regeneração na Sa ecdise \\
\hline 1 & $1 ;$ & total & 50 & $\begin{array}{l}\text { Regeneração na } 5 \text { a ecdise e morte } 10 \\
\text { dias após tornar-se adulto } \sigma^{\circ}\end{array}$ \\
\hline 1 & $3 ;$ & total & so & Norte na $5 \underline{a}$ ecdise \\
\hline 1 & $1 ;$ & tota 1 & 50 & Morte no 50 instar \\
\hline 1 & 1: & total & 50 & Morte na $5 \underline{a}$ ecdise \\
\hline 1 & $2 ;$ & total & $5 \underline{0}$ & Morte no 6 e instar \\
\hline 1 & $1 ;$ & total & 50 & Morte no 70 instar \\
\hline 1 & $1 ;$ & total & $5 \mathrm{Q}$ & Morte na $8 \underline{a}$ ecdise (adulto $\sigma^{7}$ ) \\
\hline 1 & $1:$ & total & 60 & Morte na $6 \underline{a}$ ecdise \\
\hline 1 & $1+1$ & total & $6 \underline{0}$ e $7 \underline{O}$ & Morte no 89 instar \\
\hline 1 & 1 & total & 70 & Morte no 70 instar, após 42 dias \\
\hline 1 & 3 & total & 70 & Morte na $7 \underline{a}$ ecdise \\
\hline 1 & 1: & total & 70 & Morte no 80 instar \\
\hline 1 & $1 ;$ & total & $7 \underline{0}$ & Morte na $8 \underline{a}$ ecdise (adulto $\sigma^{*}$ ) \\
\hline 1 & $1 ;$ & total & $7 \underline{0}$ & (sobreviveu e gerou descendentes) \\
\hline
\end{tabular}

o restabelecimento das condições gerais das ninfas afetadas foj aparente, pois os problemas por que passaram refletiram na maioria daquelas que chegou à fase adulta. Assim, de 6 sobreviventes $(3$ machos e 3 fêmeas $)$ que chegaram à fase adulta, 4 foram anormais: um dos machos teve 
tamanho muito inferior ao normal, pois tornou-se adulto precocemente ( 6 ecdises) e outro durou apenas 10 dias; uma das fêmeas foi estéril, tendo inclusive realizado pequena oviposição em local aberto e a outra fêmea não aceitou a corte de diferentes machos em várias tentativas de acasa 1 amento.

A mortalidade de ninfas em relação aos instares (Tabela 18) iniciou-se no 4 으, sendo crescente até o 70 instar, quando observou-se maior mortalidade (cerca de $47 \%$ ). A mortalidade acumulada atingiu aproximadamente $87 \%$, ou seja, cerca de $13 \%$ das ninfas sobreviveram até o último instar.

Tabela 18. Mortalidade e sobrevivência de ninfas de Euophrys sutrix, nos instares. Temp. $25 \pm 1,5{ }^{\circ} \mathrm{C}$, UR $70 \pm 10 \%$ e Fotofase 11-14 horas.

\begin{tabular}{cccc}
\hline & \multicolumn{2}{c}{ Mortalidade $(\%)$} & $\begin{array}{c}\text { Sobrevivência } \\
(\%)\end{array}$ \\
\cline { 2 - 3 } & Por Instar & Acumulada & 100,00 \\
\hline 10 & 0,00 & 0,00 & 100,00 \\
3o & 0,00 & 0,00 & 100,00 \\
$4 \underline{0}$ & 0,00 & 0,00 & 96,87 \\
$5 \underline{0}$ & 3,12 & 3,12 & 71,58 \\
$6 \underline{0}$ & 26,09 & 28,42 & $40,00)$ \\
$7 \underline{0}$ & 44,12 & 60,00 & $21,05^{(a)}$ \\
80 & 47,37 & 78,95 & $12,63^{(a)}$ \\
\hline
\end{tabular}

(a) Incluíram-se os adultos

(b) Incluiu-se um adult o que morreu na ecdise. 
Para as ninfas de $M$. galathea, espécie estudada por HORNER \& STARKS (1972), diferentemente de E. sutrix, a mortalidade iniciou-se já a partir do 10 ínstar, quando atingiu o maior índice. Contudo, tanto a maior mortalidade de $M$. galathea como o seu indice final de sobrevivência, foram bastante próximas àquelas observadas para a espécie em estudo.

4.2.2.5. Período de vida das ninfas

O tempo médio de vida das ninfas de $E$. sutrix que chegaram à fase adulta foi de aproximadamente 208 dias (ou quase 7 meses), sendo que as ninfas machos duraram 14 dias mais que as fêmeas. O tempo mínimo de duração foi de 168 dias e o máximo de 261 dias, ambos para ninfas machos (Tabela 19). As ninfas de Corythalia spp. viveram de 5 a 6 meses, tendo os machos menor duração que as fêmeas (CRANE, $1948)$.

As ninfas que morreram durante a fase, em média viveram 11 ? dias, com variação de 54 a 216 dias ( Tabela 19). 
Tabela 19. Duração da fase ninfal de Euophrys sutrix. Temp. $25 \pm 1,5^{\circ} \mathrm{C}$, UR $70 \pm 10 \%$ e Fotofase $11-14$ horas.

\begin{tabular}{|c|c|c|c|c|}
\hline \multirow{3}{*}{ Parâmetros ${ }^{(a)}$} & \multicolumn{4}{|c|}{ Tempo de vida das Ninfas (dias) } \\
\hline & \multirow{2}{*}{$\begin{array}{c}\text { Que Morreran } \\
\text { kntes da Pase } \\
\text { Adulta }\end{array}$} & \multicolumn{3}{|c|}{ Que Chegaram à Fase Adulta } \\
\hline & & Hacho & Fêmea & $H+F$ \\
\hline $\bar{x} \pm s(\bar{x})$ & $117,00 \pm 3,84$ & $212,00+10.79$ & $198,00 \pm 4.91$ & $207.69 \pm 7.68$ \\
\hline IV & $54-216$ & $168-261$ & $187-210$ & $168-261$ \\
\hline $\mathrm{Cl}$ & 29,32 & 15,27 & 4,76 & 13,32 \\
\hline
\end{tabular}

(a) $1 V=$ Intervalo de variação

$C V=$ Coeficiente de variação

os principais dados biologicos do desenvolvimento ninfal de $E$. sutrix são sumarizados no esquema apresentado a seguir, onde:

Interv. Ecdises $=$ intervalos de tempo, em dias, de cada ecdise;

$\underline{E}_{1} \ldots \underline{E}_{8}=$ ecdises de 1 a 8 ;

Números abaixos de $\underline{E}=$ período inativo, em dias, para cada ecdise;

$\underline{I}_{1} \ldots \underline{I}_{8}=$ instares ativos 1 a 8 ;

Números abaixo de $\underline{I}=$ período ativo, em dias, em cada instar;

Dur. Fase $=$ duração, em dias, da fase ninfal. 
Interv . Ecdises

\begin{tabular}{|c|c|c|c|c|c|c|c|c|c|c|c|c|c|c|}
\hline 18 & $T$ & 19 & 1 & 23 & 1 & 24 & 1 & 27 & 1 & 29 & 1 & 33 & 1 & 38 \\
\hline & E1 & & E2 & & E3 & & E4 & & E5 & & E6 & & E7 & \\
\hline 12 & 11 & 7 & 12 & 11 & 11 & 12 & 14 & 13 & 12 & 14 & 15 & 16 & 15 & 19 \\
\hline $\mathrm{I}_{1}$ & & $I_{2}$ & & $I_{3}$ & & $\mathrm{I}_{4}$ & & $\mathrm{I}_{5}$ & & $\mathrm{I}_{6}$ & & $\mathrm{I}_{7}$ & & $\mathrm{I}_{8}$ \\
\hline
\end{tabular}

\subsubsection{Fase adulta}

Como visto anteriormente (Tabela 19), o período de desenvolvimento das ninfas machos criadas em laboratório foi, em média, cerca de 14 dias maior que o das fêmeas. Contudo, a menor duração das ninfas fêmeas não implicou na emergência antecipada de adultos fêmeas, ou seja, a emergência de adultos machos antecedeu à das fêmeas. Isto, porque as fêmeas tardaram mais a deixar os abrigos para iniciarem a atividade, tendo a primeira fêmea surgido 21 dias após a emergência do primeiro macho e a segunda fêmea, 44 dias após, quando já havia 4 machos ativos (Tabela 20). Entretanto, a emergencia dos machos prolongou-se por mais tempo, sendo em média de 51 dias para estes e de 44 dias para as fêmeas. 
Tabela 20. Emergência acumulada dos adultos machos e fêmeas de Euophrys sutrix. Temp. $25 \pm 1,5^{\circ} \mathrm{C}$, UR $70 \pm 10 \%$ e Fotofase 11-14 horas.

\begin{tabular}{ccc}
\hline $\begin{array}{c}\text { Dias } \\
\text { para } \\
\text { Emergência }\end{array}$ & Número de Adultos & ( Acumulado) \\
\cline { 2 - 3 } 0 & Macho & Fêmea \\
\hline 21 & 1 & 0 \\
24 & 1 & 1 \\
27 & 2 & 1 \\
44 & 4 & 1 \\
49 & 4 & 2 \\
50 & 4 & 3 \\
62 & 5 & 3 \\
70 & 5 & 4 \\
91 & 6 & 4 \\
98 & 7 & 4 \\
\hline
\end{tabular}

Das ninfas criadas em laboratório, obtiveram-se 8 machos e 4 fêmeas adultas, enquanto que daquelas que foram coletadas no campo, 9 machos e 15 fêmeas. Isto totalizou 17 machos e 19 fêmeas adultas, resultando em razão sexual e proporção sexual, respectivamenta para laboratório, campo e total, de $0,33\left(10^{7}: 0,20\right) ; 0,63$ $\left(10^{7}: 1,7\right.$ 우 $)$ e $0,52\left(10^{7}: 1,19\right)$. A espécie M. galathea, estudada por HORNER \& STARKS (1972), apsesentou razão sexual de 0,41

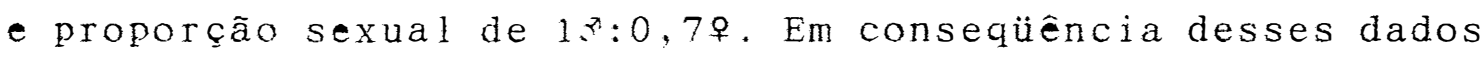
divergentes aliados ao fato de que poucos exemplares adultos foram obtidos, não foi possivel determinar a verdadeira razão sexual de E. sutrix. 


\subsubsection{Comprimento do corpo}

o comprimento do corpo dos adultos "da criação" (Tabela 21), em média foi pouco menor (ca.0,5 mm) que a média do último instar ninfal, tendo os machos apresentado redução de aproximadamente $0,8 \mathrm{~mm}$ e as fêmeas aumento de $0,5 \mathrm{~mm}$. Entre os adultos, as fêmeas foram cerca de $0,7 \mathrm{~mm}$ maiores que os machos.

Tabela 21. Comprimento médio do corpo de adultos, machos e fêmeas, originários de ninfas de Euophrys sutrix, criadas em laboratório e coletadas no campo. Temp. $25 \pm 1,5^{\circ} \mathrm{C}$, UR $70 \pm 10 \%$ e Fotofase $11-14$ horas.

\begin{tabular}{lrrr}
\hline $\begin{array}{c}\text { Adultos Originários } \\
\text { de Ninfas }\end{array}$ & \multicolumn{3}{c}{ Comprimento $(\mathrm{mm})$} \\
\cline { 2 - 4 } & $\bar{\lambda} \pm s(\overline{\mathrm{x}})$ & Interv.Variação & Coef.Variação \\
\hline De Laboratório & $9,51 \pm 1,44$ & $8,0-11,1$ & \\
- Macho & $10,23 \pm 0,03$ & $10,2-10,3$ & 12,31 \\
- Fêmea & $9,67 \pm 0,35$ & $8,0-11,1$ & 0,00 \\
- M + F & $10,68 \pm 0,32$ & $9,5-11,8$ & 10,99 \\
De Campo & $11,62 \pm 0,49$ & $10,7-13,0$ & 7,36 \\
- Macho & $11,06 \pm 0,30$ & $9,5-13,0$ & 8,41 \\
- Fêmea & & & 8,57 \\
\hline
\end{tabular}

Os adultos originários de ninfas coletadas no campo, em média foram $1,7 \mathrm{~mm}$ maiores que suas ninfas último instar, sendo os machos $1.4 \mathrm{~mm}$ e as fêmeas $2,3 \mathrm{~mm}$ 
maiores que os respectivos sexos ninfais. As fêmeas adultas foram $1 \mathrm{~mm}$ maiores que os machos e ambos tiveram comprimentos maiores que os adultos "da criação" (Tabela 21). Isto demonstrou que, no laboratório, houve produção de individuos subdesenvolvidos, provavelmente devido a problemas nutricionais, como foi anteriormente comentado.

\subsubsection{Dimorfismo sexual}

No último ínstar ninfal pode-se separaros sexos de E. sutrix: as ninfas que originaram machos adultos apresentaram as extremidades dos palpos em formato pequena clava, que foi chamada de "quase-clava" por comstock $(1948)$.

As principais diferenças entre os sexos surgiram. porém. somente na fase adulta, quando os machos apresentaram coloração geral mais escura e maior pilosidade nas pernas I e II, que as fêmeas. Entretanto, o que mais diferenciou os sexos foi a extremidade do palpo, que se apresentou expandida nos machos (Figura 4). Esta é uma característica generalizada para as aranhas e Comstock (1948) a descreveu e figurou com detalhes para diversas famílias e espécies. O autor citou-a como "bulbo genital", sendo uma estrutura extremamente complexa. utilizada para transferência de sêmen para o poro genital ou epigino da fêmea.

Ventralmente, no abdome, o que se destacou foi a presença do epigino, caracterizando as fêmeas. 


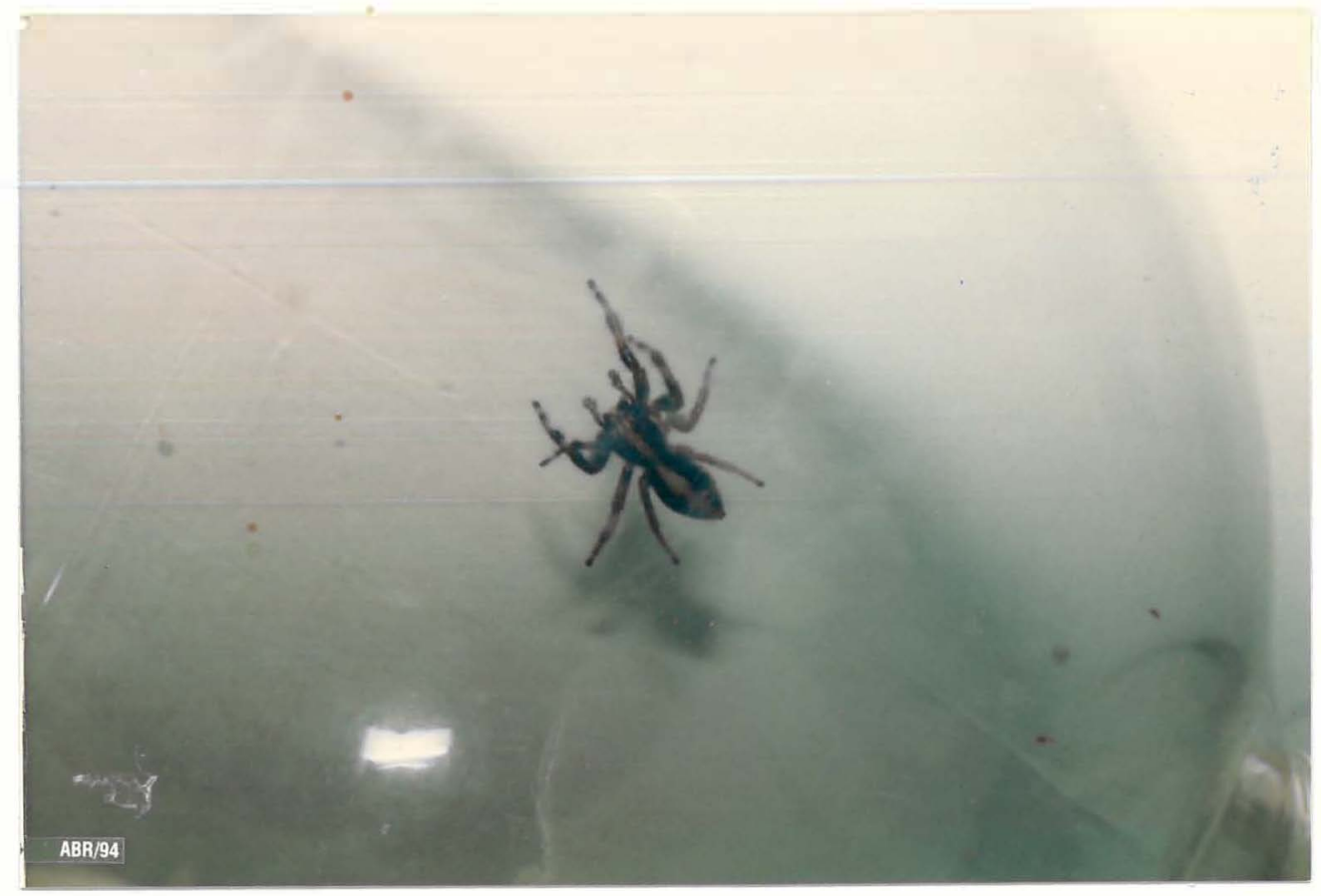

Figura 4. Adulto macho de Euophrys sutrix, tendo, à frente do cefalotórax, os palpos distendidos e expandidos nos ápices. Aumento de $1,5 \mathrm{x}$.

\subsubsection{Consumo de presas}

O consumo médio diário de $M$. domestica em diferentes etapas biológicas dos adultos de E. sutrix, é apresentado na Tabela 22, juntamente com os dados de consumo médio das ninfas de último ínstar.

Observou-se que o consumo dos machos virgens e dos acasalados foi muito próximo entre si e também das ninfas de último ínstar, sendo inferior ao das fêmeas 
virgens e das fêmeas em pré-oviposição.

Tabela 22. Consumo médio diário de Musca doméstica por ninfas de último ínstar e por adultos de Euophrys sutrix, em diferentes etapas biológicas. Temp. $25 \pm 1,5^{\circ} \mathrm{C}$, UR $70 \pm 10 \%$ e Fotofase $11-14$ horas.

\begin{tabular}{|c|c|c|c|c|c|c|}
\hline \multirow[b]{4}{*}{ Parâmetros (a) } & \multicolumn{6}{|c|}{ Número Kédio de Moscas Consumidas por dia, por Aranha } \\
\hline & \multirow{3}{*}{$\begin{array}{l}\text { Kinfa de } \\
\text { Ultimo } \\
\text { Instar }\end{array}$} & \multicolumn{5}{|c|}{ Adul to } \\
\hline & & \multicolumn{2}{|c|}{ Virgem } & \multicolumn{3}{|c|}{ Acasalado } \\
\hline & & Macho & Fêmea & Macho & Fêmea pré $(b)$ & Fêrea pós $(\mathrm{c})$ \\
\hline $\bar{x} \pm s(\bar{x})$ & $0,90 \pm 0,13$ & $1,08 \pm 0,10$ & $1,70 \pm 0,20$ & $0,96 \pm 0,15$ & $2,84 \pm 0,43$ & $0,43 \pm 0,06$ \\
\hline IV & $0,33-1,33$ & $0,50-1,33$ & $1,00-2,56$ & $0,27-1,45$ & $1,42-5,33$ & $0,33-0,67$ \\
\hline $\mathrm{CV}$ & 38,58 & 25,41 & 33,10 & 42,72 & 43,32 & 31,16 \\
\hline
\end{tabular}

(a) IV = Intervalo de variação $C V$ = Coeficiente de variação

(b) Fêmea copulada, ell período de pré-oviposição.

(c) Fêmea ao final do ciclo, em período de pós-oviposição.

As fêmeas virgens e as em período de préoviposição consumiram, cada uma, por dia, respectivamente cerca de $0,8 \in 1,9$ moscas a mais que as ninfas, $0,6 \in 1,8$ a mais que os machos virgens e 0,7 e 1,9 moscas a mais que os machos acasalados. A média de consumo dos adultos totais, excluindo fêmeas em pós-oviposiçã foj de 1,65 moscas por aranha por dia.

A idade dos adultos ou o tempo decorrido 
da cópula, não teve influência no consumo de presas (Tabelas 23 e 24 ).

Tabela 23. Consumo médio diário de Musca domestica por adultos acasalados de Euophrys sutrix, de diferentes faixas etárias. Temp. $25 \pm 1,5^{\circ} \mathrm{C}$, UR $70 \pm 10 \%$ e Fotofase 11-14 horas.

\begin{tabular}{|c|c|c|c|c|c|}
\hline \multicolumn{2}{|c|}{ Hacho Acasalado } & \multicolumn{2}{|c|}{ Fêmea em Pré-oviposição } & \multicolumn{2}{|c|}{ Fêmea Final do ciclo } \\
\hline $\begin{array}{l}\text { Faixa Etária } \\
\text { (dias) }\end{array}$ & $\begin{array}{c}\text { Consumo } \\
\text { (mosca/dia) }\end{array}$ & $\begin{array}{c}\text { Faiga Etaria } \\
\text { (dias) }\end{array}$ & $\begin{array}{c}\text { Consumo } \\
(\text { mosca/dia })\end{array}$ & $\begin{array}{c}\text { Faixa Etária } \\
\text { (dias) }\end{array}$ & $\begin{array}{c}\text { Consumo } \\
\text { (mosca/dia) }\end{array}$ \\
\hline $20-41$ & 0,92 & $7-12$ & 2,55 & $170-179$ & 0,31 \\
\hline $73-81$ & 1,01 & $45-52$ & 2,66 & $203-219$ & 0,49 \\
\hline $88-111$ & 1,01 & $64-92$ & 2,34 & 232 & 0,30 \\
\hline
\end{tabular}

Tabela 24. Consumo médio diário de Musca domestica por adultos acasalados de Euophrys sutrix, em relação à faixa de tempo decorrido da cópula.

\begin{tabular}{ccccc}
\hline \multicolumn{2}{c}{ Macho Acasalado } & & Fêmea em Pré-oviposição \\
\cline { 1 - 2 } $\begin{array}{c}\text { Faixa } \\
\text { (dias) }\end{array}$ & $\begin{array}{c}\text { Consumo } \\
\text { (mosca/dia) }\end{array}$ & & $\begin{array}{c}\text { Faixa } \\
\text { (dias) }\end{array}$ & $\begin{array}{c}\text { Consumo } \\
\text { (mosca/dia) }\end{array}$ \\
\hline $8-17$ & 0,97 & $1-19$ & 2,76 \\
$37-48$ & 0,85 & $37-48$ & 2,50 \\
$58-86$ & 1,07 & $58-86$ & 2,34 \\
\hline
\end{tabular}




\section{$4 \cdot 2 \cdot 3 \cdot 4 \cdot \operatorname{Reprodução~}$}

4.2.3.4.1. Acasalamento e Corte

Os acasalamentos foram realizados, em média, 19 dias após o início da fase adulta. Foram considerados bem sucedidos quando o macho foi atraído e deslocou-se para onde a fêmea se encontrava, seguindo-se a corte.

FOELIX (1982) e ROBINSON

$(1982)$

descreveram detalhadamente todo o processo de corte de várias aranhas, inclusive de salticídeos. Embora o primeiro autor tenha incluído a ocorrência de estímulos químicos, ambos deram maior importância aos sinais visuais para início da corte, estes envolvendo movimentos e vibração de corpo, de pernas e de palpos. O segundo autor citou que os "repertórios" de corte podem diferir para cada espécie, podendo estar envolvidos também elementos olfatórios e acústicos.

Para Estrix observou-se que, provavelmente, estímulos químicos, liberados pelas fêmeas, foram os responsáveis pela atração dos machos. Isto, porque a maioria destes encaminhou-se para o local da fêmea, quando esta se encontrava no interior do abrigo, não havendo, portanto, sua visualização. Entretanto. em alguns poucos casos, o macho não se manifestou, até que a fêmea, saindo do abrigo e movimentando-se, causou o seu interesse, 
demonstrando que, para estes casos, a visão foi o elemento mais importante na atração do macho (aqui, fica a indagação do motivo pelo qual a fêmea deixou o seu abrigo, exibindo-se para o macho: haveria também o envolvimento de odores do macho? ).

Após a detecção da fêmea, o macho encaminhou-se para ela. FOELIX (1982) citou a ocorrência de movimentos em ziguezague (a que designou de "dança do ziguezague") e balanço do abdome, para cima e para baixo, podendo a fêmea, conforme a espécie, permanecer passiva vigiando o macho, responder a ele vibrando os palpos ou até mesmo imitar o seus movimentos de corte.

Em E. sutrix cerca de metade dos machos realizou algo semelhante à "dança do ziguezague", quando o caminhamento foi bastante lento. Os restantes encaminharamse rapidamente para onde a fêmea se encontrava, não realizando os característicos movimentos de corte, passando logo para a cópula, após o "toque-de-pernas".

$$
\text { O "toque-de-pernas" foi o primeiro contato }
$$

entre os sexos, quando macho e fêmea tocaram-se simultaneamente pelos tarsos das duas pernas anteriores (pernas I). Contudo, isto aconteceu quando as fêmeas foram receptivas; quando não, a fêmea, a lém de não corresponder ao toque, permaneceu batendo suas pernas anteriores nas paredes, como que tamborilando, talvez para intimidar o macho.

$$
\text { Após o toque-de-pernas, iniciou-se }
$$

realmente a corte, ocorrendo geralmente todos os movimentos 
anteriormente citados. Entretanto, FOELIX (1982) relatou que o toque de pernas é o último elemento da corte, passando-se, então, para a cópula .

O tempo médio necessário para o macho dar início à escalada das paredes dos recipientes, chegar próximo à fêmea e realizar o toque de pernas é mostrado na Tabela 25 . Observou-se que houve grande variabilidade, tendo esses antecedentes da cópula durado de 4 a 33 minutos e em média cerca de 16 minutos. A corte propriamente dita (ocorrência após o toque-de-pernas), durou, em média, cerca de 4 minutos. HORNER \& STARKS (1972) obtiveram que a corte de $M$. galathea durou de 2 a 10 minutos.

Tabela 25. Tempo decorrido para os eventos de cópula, desde o acasalamento de Euophrys sutrix. Temp. $25 \pm 1,5^{\circ} \mathrm{C}$, UR $70 \pm 10 \%$ e Fotofase $11-14$ horas.

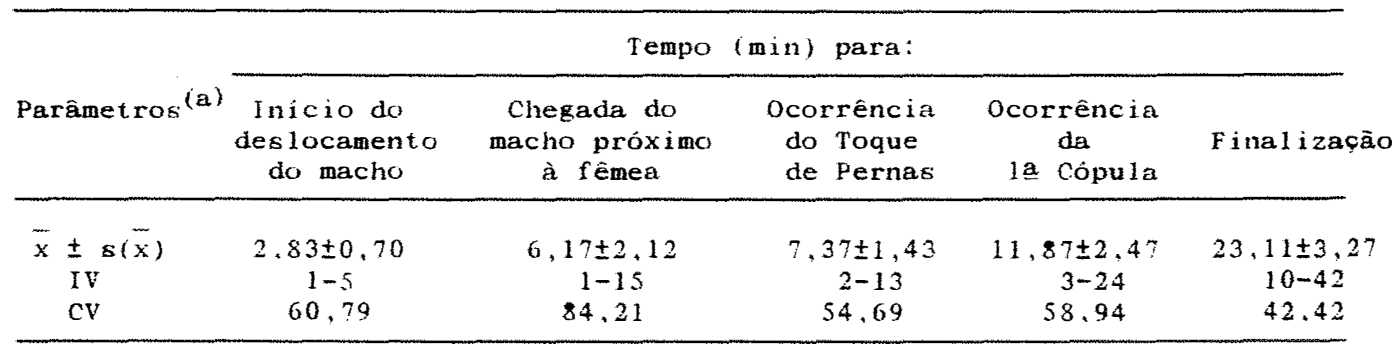

(a) IV = Intervalo da variação $\mathrm{CV}=$ Coeficiente de variação 


\subsection{Cópula}

A cópula ocorreu externamente ao casulo em cerca de $60 \%$ dos casos. O macho subiu pelo cefalotórax da fêmea, ficando com a parte do abdome sobre ele, enquanto que a fêmea girou seu abdome em $90^{\circ}$, para que a região dos palpos do macho atingisse a região de epigino, formando posição próxima à um ípsilon (Y).

Em aranhas, a transferência do esperma é indireta e ocorre por intermédio dos palpos. Montgomery ${ }^{4}$, citado por ROBINSON (1982), descreveu que isso acontece em dois atos: no primeiro, o macho ejeta o sêmen para uma "teia-de-esperma" e em seguida coleta-o com os palpos; mais tarde, durante a cópula, o esperma é novamente "ejaculado", dos palpos para o orifício genital da fêmea. A "teia-deesperma", de acordo com ROBINSON (1982), pode ser construida, entre outros locais, próxima ao abrigo da fêmea. Entretanto, CRANE (1948) observou que em Corythalia spp. não ocorreu "teia-de-esperma".

Para E. sutrix, em nenhuma ocasião foi vista a deposição ou a coleta do sêmen. Observou-se que alguns machos, antes de galgarem as fêmeas, e mesmo durante a cópula, movimentaram repetidamente o abdome contra a parede do recipiente ou contra a teia do abrigo da fêmea.

MONTGOMERY: T.H. Studies on the habits of spiders, particulary those of the mating period. Proc. Acad. Nat. Sci., philadelphia, 55: 59-149, 1903. 
Esse movimento abdominal, segundo ROBINSON (1982), pode estimular a ejaculação.

FOELIX (1982) citou que a inserção do palpo na abertura genital da fêmea é consecutiva, isto é, o macho insere um dos palpos, ficando posicionado num dos lados do abdome da fêmea e, depois, troca de lado para inserir o outro palpo. Em E. sutrix observou-se esse mesmo comportamento, com exceção de um macho que copulou por três vezes, com duas trocas de lado, e de outro que não trocou de lado. Este último macho, provavelmente utilizou os dois palpos ao mesmo tempo (FOELIX, 1982 citou esta possibilidade) ou um após o outro, considerando-se como tendo ocorrido somente uma cópula.

A primeira cópula (primeiro lado) ocorreu, em média, cerca de 12 minutos após o acasalamento e 4 minutos depois do toque de pernas (Tabela 25), demonstrando que após o toque de pernas houve prosseguimento da corte. Ao todo, isto é, desde a colocação do macho próximo à fêmea até a finalização da última cópula, os eventos duraram de 10 a 42 minutos, e em média 23 minutos (Tabela 25 ).

O tempo de duração das cópulas foi de 8,5 minutos, sendo que a primeira teve 0,69 min $(41 \mathrm{seg})$ a mais que a segunda (Tabela 26). Essa diferença para maior na $1 \underline{a}$ cópula, deveu-se ao longo tempo (11 min) dispendido pelo macho que copulou somente uma vez, tendo os demais machos requerido de 2 a 6 minutos para a 1 a cópula. 
Tabela 26. Tempo de duração das cópulas de Euophrys sutrix. Temp. $25 \pm 1,5^{\circ} \mathrm{C}$, UR $70 \pm 10 \%$ e Fotofase $11-14$ horas.

\begin{tabular}{|c|c|c|c|}
\hline \multirow{2}{*}{ Parâmetros $\{\mathrm{a}\}$} & \multicolumn{3}{|c|}{ Tempo (min) para as cópulas } \\
\hline & $1 \underline{\mathrm{a}}$ & $2 \underline{\mathrm{a}}$ & Total \\
\hline $\begin{array}{c}\bar{x} \pm s(\bar{x}) \\
I V \\
C V\end{array}$ & $\begin{array}{c}4,86 \pm 1,14 \\
2-11(b) \\
62,25\end{array}$ & $\begin{array}{c}4,17 \pm 0,48 \\
3-6 \\
28,06\end{array}$ & $\begin{array}{c}8,50 \pm 0,53 \\
7-11 \\
17,79\end{array}$ \\
\hline
\end{tabular}

(a) IV = Intervalo da variação

$C V=$ Coeficiente de variação

(b) O limite superior $(11 \mathrm{~min})$ pertenceu ao macho que realizou apenas uma cópula.

Após as cópulas, os machos retiraram-se do local ou foram "enxotados" pelas fêmeas e estas encaminharam-se para o interior de seus abrigos.

As fêmeas copuladas apresentaram o epigino coberto por um tampão, tendo ROBINSON (1982) citado que esse tampão ocorre para diversas espécies de aranhas, não havendo um consenso sobre quem o produz. A função do tampão, segundo o mesmo autor, é de impedir nova cópula. Porém, as fêmeas de E. sutrix, já copuladas, não aceitaram a corte de novos machos, repelindo-os "veementemente", não sendo a presença do tampão que impediu nova cópula. Assim, considerou-se que, provavelmente, o tampão tenha a função de impedir que o sêmen depositado no duto espermático escorra para o exterior, visto que a posiça da abertura genital da fêmea (na face ventral do abdome) é propícia a isto. As fêmeas 
copuladas das espécies Corythalia spp. e M. galathea, sob hi pótese a lguma aceit aram nova cópula, mostrando hosti lidade aos machos (CRANE, 1948; HORNER \& STARKS, 1972). Esses autores observaram que os machos copularam com várias fêmeas virgens, o mesmo tendo-se obtido para a espécie em estudo. As fêmeas, após a cópula, passaram alguns dias abrigadas, retornando à atividade externa geralmente para se alimentarem, quando então consumiram exagerado número de presas. As fêmeas férteis permaneceram abrigadas. em média, durante 5,2 dias (de 1 a 8 dias), enquanto que as estéreis comportaram-se diferentemente: uma delas permaneceu por 10 dias abrigada, enquanto que outra continuou ativa após a cópula, por 6 dias, passando à inatividade, no abrigo, durante 16 dias.

Decorridos em média 18 dias ( 7 a 28 dias) da cópula, as fêmeas férteis iniciaram a construção do primeiro casulo-de-postura.

\subsection{Casulos-de-postura}

Os casulos-de-postura abrigaram não somente ovissacos e ovos, mas também a aranha-mãe. Foram construídos em quatro formatos básicos: ovais, semi-ovais, circulares ou triangulares, predominando o tipo oval. Os três primeiros tipos citados tiveram duas aberturas e os triangulares, duas ou três.

Nos recipientes tubulares, os casulos 
foram construidos nas bordas da circunferência superior, junto à tela; naqueles com gargalo, no próprio gargalo.

As dimensões dos casulos (comprimento $\mathrm{x}$ maior largura! variaram, tendo de 25 a $50 \mathrm{~mm}$ de comprimento $(25 \times 24 ; 50 \times 28)$ e de 18 a $32 \mathrm{~mm}$ de largura $(31 \times 18 ; 40 \times 32)$, resultando em média de 36x24 mm. CRANE (1948) observou que o casulo de Corythalia spp. teve $25 \times 18 \mathrm{~mm}$. O tamanho do casulo de postura é proporcional ao tamanho da fêmea (FOELIX, 1982) e assim, os casulos de E. sutrix foram maiores que os de Corythalia spp. porque as fêmeas da primeira espécie tiveram comprimento médio de $10,9 \mathrm{~mm}$ e as das espécies de Corythalia, 6,1 mm, em média.

Os tamanhos (obtidos pela multiplicação das dimensões) dos casulos viáveis (casulos com postura viável) foram maiores que os dos não viáveis, o que reduziu a média total (Tabela 27). Essa diferença provavelmente ocorreu devido a alguma alteração fisiológica sofrida pelas fêmeas estéreis ou não fertilizadas.

Os tipos de recipientes de criação influenciaram os tamanhos dos casulos viáveis e totais, sendo maiores nos recipientes tubulares (Tabela 28). Isto é facilmente explicável, pela maior área disponível para sua construção. nesse tipo de recipiente.

Foram construídos até 5 casulos por fêmea. resultando numa média de aproximadamente 2,7 casulos por fêmea (Tabela 29). As fêmeas férteis elaboraram maior número de casulos nos recipientes com gargalo (Tabela 30), este 
fato talvez para compensar o menor tamanho dos casulos, construídos nesses recipientes.

\section{$4.2 \cdot 3 \cdot 4 \cdot 4$. Ovissacos}

O ovissaco ou saco-de-ovos constituiu-se de um invólucro dos ovos, de formato oval ou circular, confeccionado no interior do casulo de postura.

As dimensões dos ovissacos variaram de 9, 5 a 29,0 mm de comprimento $(9,5 \times 9,5: 29,0 \times 21,0)$ e de 8,0 a $21,0 \mathrm{~mm}$ de largura $(13,0 \times 8,0 ; 29,0 \times 21,0)$ e tiveram em média perto de $14,0 \times 12,0 \mathrm{~mm}$. Espécies de Corythalia spp., de acordo com CRANE (1948), apresentaram ovissacos com $7 \times 9 \mathrm{~mm}$, em média.

Os ovissacos viáveis, que foram da ordem de $29 \%$ do total de ovissacos, em média tiveram maior tamanho que os inviáveis (Tabela 27), acompanhando o observado para os casulos-de-postura.

Entre os tipos de recipientes, houve pouca diferença nos tamanhos dos ovissacos viáveis ou totais, percebendo-se que o tamanho do ovissaco não dependeu do tamanho do casulo (Tabela 28), relacionando-se mais com o tamanho da postura.

Cada fêmea produziu, em média, cerca de 6,5 ovissacos, sendo 2,4 em cada casulo-de-postura. Entretanto, a média de ovissacos viáveis foi de 2.1 por fêmea (Tabela 29). Para M. galathea. HORNER \& STARKS (1972) 
observaram a produção de 8,3 ovissacos por fêmea e ROACH (1988) obteve para P. audax 2,75 ovissacos por fêmea. Esses autores não relataram o tipo de ovissaco (viável ou não).

Nos recipientes com gargalo foram produzidos um pouco mais de ovissacos que nos tubulares (Tabela 30), não havendo relação entre tamanho e número de ovissacos produzidos ou sejam, ovissacos maiores não implicaram na redução de seu número (Tabelas 28 e 30 ).

Tabela 27. Tamanho médio das estruturas de postura e das posturas, produzidas por fêmeas viáveis e pelo total de fêmeas de Euophrys sutrix. Temp. $25 \pm 1,5^{\circ} \mathrm{C}$, UR $70 \pm 10 \%$ e Fotofase $11-14$ horas.

\begin{tabular}{lccc}
\hline $\begin{array}{l}\text { Estrutura de } \\
\text { postura e } \\
\text { Postura }\end{array}$ & $\overline{\mathrm{x}} \pm \mathrm{s}(\overline{\mathrm{x}})$ & Tamanho $\left(\mathrm{mm}^{2}\right)$ & \\
\cline { 2 - 4 } & & & \\
\hline Casulo & & & \\
- viável & $950,97 \pm 106,23$ & $628,8-1400,0$ & 31,60 \\
- total & $896,68 \pm 86,28$ & $628,8-1401,2$ & 30,43 \\
Ovissaco & & & \\
- viável & $230,80 \pm 30,86$ & $117,0-388,5$ & 37,82 \\
- total & $166,32 \pm 10,49$ & $117,0-255,6$ & 21,86 \\
Postura & $41,12 \pm 3,68$ & $25,7-61,4$ & 28,28 \\
\hline total & & & \\
\hline
\end{tabular}


Tabela 28. Tamanho médio das estruturas de postura e das posturas, produzidas por fêmeas viáveis e totais de Euophrys sutrix em relação ao tipo do recipiente utilizado, sendo $\mathrm{T}=\mathrm{tubular}$ e $\mathrm{G}=\mathrm{com}$ gargalo. Temp. $25 \pm 1,5^{\circ} \mathrm{C}, \quad$ UR $70 \pm 10 \%$ e Fotofase 11-14 horas.

\begin{tabular}{|c|c|c|c|c|}
\hline \multirow{2}{*}{$\begin{array}{l}\text { Estrutura de } \\
\text { postura e } \\
\text { Postura }\end{array}$} & \multicolumn{4}{|c|}{ Tamanho $\left(\mathrm{mm}^{2}\right)$} \\
\hline & & $\bar{x} \pm s(\bar{x})$ & Interv. Variação & Coef. Variação \\
\hline \multirow[t]{2}{*}{ Casulo viável } & $\mathrm{T}$ & $1030,80 \pm 148,24$ & $670,0-1400,0$ & 32,20 \\
\hline & $\mathrm{G}$ & $817,93 \pm 133,21$ & $628,8-1075,0$ & 28,21 \\
\hline \multirow[t]{2}{*}{ Casulo total } & $\mathrm{T}$ & $1021,18 \pm 117,38$ & $696,0-1401,2$ & 28,16 \\
\hline & G & $709,92 \pm 44,80$ & $628,8-834,9$ & 12,62 \\
\hline \multirow[t]{2}{*}{ Ovissaco viável } & $\mathrm{T}$ & $233,47 \pm 51,79$ & $172,0-388,5$ & 44,37 \\
\hline & $\mathrm{G}$ & $228,12 \pm 41,92$ & $117,0-311,7$ & 36,75 \\
\hline \multirow[t]{2}{*}{ Ovissaco total } & $\mathrm{T}$ & $177,70 \pm 16,20$ & $147,8-255,6$ & 22,33 \\
\hline & $\mathrm{G}$ & $154,93 \pm 13,05$ & $117,0-200,2$ & 20,64 \\
\hline \multirow[t]{2}{*}{ Postura total } & $\mathrm{T}$ & $43,26 \pm \quad 5,20$ & $30,8-\quad 61,4$ & 26,89 \\
\hline & G & $38,98 \pm$ & $25,7-$ & 32,20 \\
\hline
\end{tabular}

Tabela 29. Número de estruturas de postura produzidas por fêmea, número de ovissacos contidos no casulo de postura e número de ovos depositados em cada ovissaco de Euophrys sutrix. Temp. $25 \pm 1,5^{\circ} \mathrm{C}$, UR $70 \pm 10 \%$ e Fotofase 11-14 horas.

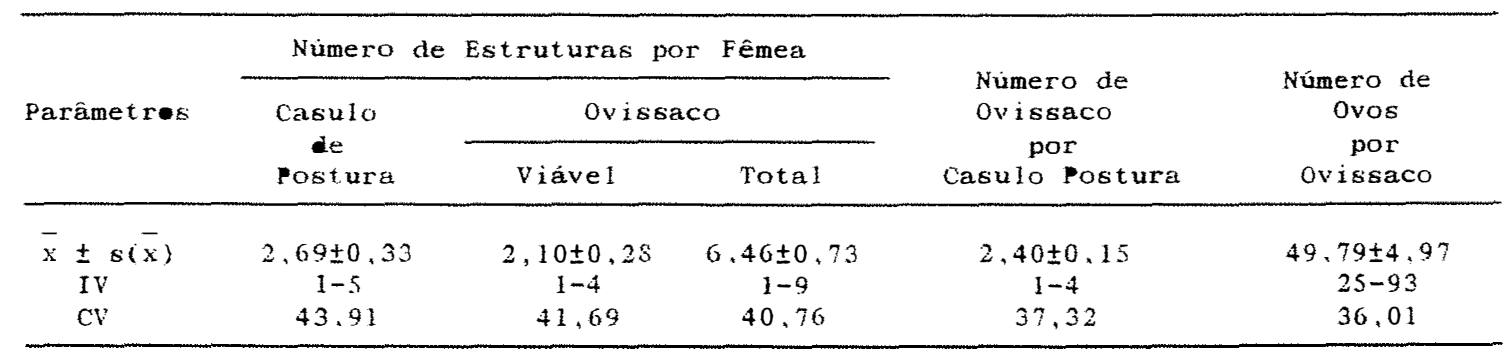


Tabela 30. Produção de estruturas de postura e de ovos, por fêmeas viáveis de Euophrys sutrix, segundo o tipo do recipiente utilizado, $(T=$ tubular $e$ $G=c o m$ gargalo. Temp. $25 \pm 1,5^{\circ} \mathrm{C}$, UR $70 \pm 10 \%$ e Fotofase 11-14 horas.

\begin{tabular}{|c|c|c|c|}
\hline \multirow{2}{*}{$\begin{array}{l}\text { Estruturas de } \\
\text { Postura e Ovos } \\
\text { por Recipiente }\end{array}$} & \multicolumn{3}{|c|}{ Número } \\
\hline & $\bar{x} \pm s(\bar{x})$ & Interv. Variação & Coef. Variação \\
\hline \multirow[t]{2}{*}{ Casulos } & $2,17 \pm 0,31$ & $1-3$ & 34,74 \\
\hline & $3,00 \pm 0,71$ & $1-4$ & 47,14 \\
\hline \multirow{2}{*}{ Ovissacos } & $5,67 \pm 0,95$ & $2-8$ & 41,26 \\
\hline & $6,25 \pm 1,80$ & $1-9$ & 57,50 \\
\hline \multirow[t]{2}{*}{ Ovos } & $284,83 \pm 58,32$ & $50-424$ & 50,15 \\
\hline & $291,25 \pm 75,35$ & $93-459$ & 51,74 \\
\hline
\end{tabular}

\section{$4 \cdot 2 \cdot 3 \cdot 4 \cdot 5$. Ovipos ição}

A oviposição, aparentemente, foi realizada aos poucos, pois a fêmea, eventualmente, saía do casulo para se alimentar, retornando pouco depois.

Foi possível determinar a época do início da oviposiça para cerca da metade das fêmeas, tendo a primeira postura sido realizada de 14 a 97 dias após a cópula e em média 42 dias após. Como cada ovissaco conteve uma postura, o número de posturas foi equivalente a número de ovissacos. Contudo, algumas fêmeas, ao final do período reprodutivo, apresentaram ovissacos sem ovos e contendo apenas uma substância amorfa endurecida. 
A postura foi composta de duas ou três camadas de ovos, colados uns aos outros, formando um bloco circular ou levemente oval. As dimensões médias das posturas totais foram de aproximadamente $7,0 \times 6,0 \mathrm{~mm}$, variando de $3,0 \times 2,5$ a $11,0 \times 9,0 \mathrm{~mm}$, ocupando cerca de $1 / 4$ da área do ovissaco (Tabela 27). O tamanho da postura não foi influenciado pelo tipo de recipiente utilizado (Tabela 28). Em cada ovissaco ou postura, havia cerca de 50 ovos (Tabela 29). Na espécie $M$. galathea, a fêmea ovipositou em média 19 ovos por ovissaco, variando de 9 a 31 ovos (HORNER \& STARKS, 1972); para P. audax a média foi de 64 ovos por ovissaco, com variação de 15 a 164 ovos (ROACH, $1988)$

Os tipos de recipientes utilizados não tiveram influência no número de ovos depositados (Tabela $30)$.

No interior e ao redor dos ovissacos, que foram abertos após a emergência das ninfas, encontraram-se ovos inviáveis, de coloração amarela ou castanha, prélarvas, larvas e ninfas I, mortas, tanto originários de fêmeas férteis como de "estéreis" (fêmeas que não originaram ninfas I, vivas). Pela contagem desses elementos e adicionando-se o número de ninfas emergentes, obteve-se o total de ovos depositados por fêmea (Tabela 31). 
Tabela 31. Número de ovos inviáveis, de jovens mortas no interior do casulo, de larvas emergentes e total de ovos, originários de fêmeas férteis, "estéreis" e totais de Euophrys sutrix. Temp. $25 \pm 1,5^{\circ} \mathrm{C}$, UR $70 \pm 10 \%$ e Fotofase $11-14$ horas.

\begin{tabular}{|c|c|c|c|c|c|}
\hline \multirow[b]{2}{*}{ Fêmeas } & \multirow[b]{2}{*}{ Parâmetros } & \multicolumn{4}{|c|}{ Número por Fêmea } \\
\hline & & $\begin{array}{c}\text { Ovos } \\
\text { Inviáveis }\end{array}$ & $\begin{array}{l}\text { Jovens } \\
\text { Mortas }\end{array}$ & $\begin{array}{r}\text { Larvas } \\
\text { Emersas }\end{array}$ & $\begin{array}{l}\text { Ovos }(1) \\
\text { Totais }\end{array}$ \\
\hline Férteis & $\begin{array}{l}\bar{x} \pm s(\bar{x}) \\
\text { IV } \\
C V\end{array}$ & $\begin{array}{c}103,10 \pm 20,18 \\
3-171 \\
61,91\end{array}$ & $\begin{array}{c}89.20 \pm 19.88 \\
0-166 \\
70,48\end{array}$ & $\begin{array}{c}1,20 \pm 0,55 \\
0-4 \\
-\end{array}$ & $\begin{array}{c}287,40 \pm 43,48 \\
50-459 \\
47,86\end{array}$ \\
\hline Estéreis & $\begin{array}{l}\bar{x} \pm s(\bar{x}) \\
\text { IV } \\
C V\end{array}$ & $\begin{array}{c}310,33 \pm 49,54 \\
229-400 \\
27,65\end{array}$ & $\begin{array}{c}56,67 \pm 56,67 \\
0-170 \\
-\end{array}$ & $\begin{array}{c}2,67 \pm 2,67 \\
0-8 \\
-\end{array}$ & $\begin{array}{c}369,67 \pm 74,03 \\
229-480 \\
34,38\end{array}$ \\
\hline Totais & $\begin{array}{l}\bar{x} \pm s(\bar{x}) \\
\text { IV } \\
C V\end{array}$ & $\begin{array}{c}150,92 \pm 31,06 \\
3-400 \\
74,20\end{array}$ & $\begin{array}{c}81,69 \pm 19,16 \\
0-170 \\
80,57\end{array}$ & $\begin{array}{c}1,54 \pm 0,69 \\
0-8 \\
-\end{array}$ & $\begin{array}{c}306,38 \pm 37,44 \\
50-480 \\
44,07\end{array}$ \\
\hline
\end{tabular}

(1) Total de ovos = ovas inviáveis + jovens mortas + larvas e ninfas emersas.

As fêmeas férteis depositaram, cada uma, uma média de aproximadamente 287 ovos, dos quais 103 $(35,87 \%)$ foram totalmente inviáveis, 89 (31,04\%) originaram jovens que morreram antes da emergência e $1(0,42 \%)$ originou larva emergente, resultando em viabilidade de ovos de $32,67 \%$

Cada fêmea "estéril" depositou cerca de 369 ovos, número este, maior que o das férteis, sendo que $310(83,95 \%)$ foram totalmente inviáveis e os demais originaram jovens que morreram precocemente. Como conseqüencia, do total de ovos postos por fêmea (ca.306). 76,25\% foram inviáveis, ou seja, a viabilidade do total de 
ovos foi de $23,57 \%$, esta $9,10 \%$ menor que a de fêmeas férteis ( Tabela 31 ).

O número de ovos depositados por fêmea de E. sutrix, superou o das espécies $M$. galathea e P. audax, cujas oviposições, por fêmea, foram, respectivamente, de 158 e 192 ovos (HORNER \& STARKS, 1972; ROACH, 1988), não tendo os autores informado sobre o percentual de viabilidade dos ovos. Entretanto, HORNER \& STARKS (1972) observaram haver inviabilidade de ovos na espécie estudada e a discutiram. citando possíveis causas, relatadas por outros autores.

\subsubsection{Longevidade}

Os adultos provenientes de ninfas criadas em laboratório, apresentaram longevidade média de aproximadamente 161 dias, havendo sobrevivência até o máximo de 182 dias. Os machos foram, em média, cerca de 8 dias mais longevos que as fêmeas e o período máximo de vida adult a (282 dias) foi observado para machos. Todavia houve macho que morreu mais precocemente que a fêmea (Tabela 32 ).

A longevidade média de adultos originários de ninfas coletadas no campo, foi também pouco maior para machos, porém a máxima longevidade pertenceu a fêmeas. Esses adultos, em média viveram por cerca de 245 dias, período esse bem mais elevado (quase 3 meses a mais) que os adultos provenientes de ninfas criadas em laboratório. As fêmeas mais longevas apresentaram uma diferença, em relação àquelas 
de laboratório, de 144 dias a mais (Tabela 32).

Tabela 32. Longevidade dos adultos de Euophrys sutrix. Temp. $25 \pm 1,5^{\circ} \mathrm{C}$, UR $70 \pm 10 \%$ e Fotofase $11-14$ horas.

\begin{tabular}{lccc}
\hline $\begin{array}{l}\text { Longevidade } \\
\text { dos Adultos } \\
\text { originários }\end{array}$ & $\overline{\mathrm{x}} \pm \mathrm{s}(\overline{\mathrm{x}})$ & Tempo (dias) \\
\cline { 2 - 4 } Da criação: & & & \\
Macho & $163,00 \pm 34,21$ & $10-282$ & 55,52 \\
Fêmea & $155,33 \pm 33,28$ & $90-199$ & 37,11 \\
$M+F$ & $160,70 \pm 24,92$ & $10-282$ & 49,05 \\
& & & \\
De jovens de campo: & & $174-304$ & 19,57 \\
Macho & $251,50 \pm 20,09$ & $111-343$ & 29,55 \\
Fêmea & $242,50 \pm 22,66$ & $111-343$ & 25,94 \\
M $+\mathrm{F}$ & $245,50 \pm 15,92$ & & Coef. Variação \\
\hline
\end{tabular}

Como o alimento fornecido foi o mesmo para todas as aranhas adultas, conclui-se que a dieta (presas) das ninfas criadas em laboratório desde sua emergência, foi nutricionalmente deficiente, influenciando até na longevidade dos adultos.

o ciclo de vida das aranhas, desde a emergência das ninfas até a morte dos adultos, foi de $374,29 \pm 23,74$ dias para machos, com variação de 270 a 450 dias; $353,67 \pm 28,47$ dias para fêmeas, variando de 300 a 397 dias e, no geral, de $368,10 \pm 18,08$ dias e variação de 270 a 450 dias. 


\subsubsection{Emergência e Dispersão das ninfas}

Durante as emergências e dispersões das ninfas descendentes, as fêmeas permaneceram no interior dos casulos, provavelmente cuidando da(s) postura(s).

No geral, ocorreram até quatro dispersões por fêmea, contudo duas foram mais comuns e apenas para uma fêmea houve quatro dispersões.

A primeira disperão iniciou-se, em média. aos 60 dias da cópula; a segunda 20 dias após a primeira dispersão e a terceira, 12 dias após a segunda (Tabela 33 ).

Entre o final de uma dispersão e o início de outra, decorreram em média cerca de 7 dias, sendo que cada dispersão durou de 12 a 17 dias (Tabela 33 ). Entretanto, cerca de $47 \%$ das ninfas dispersaram-se num período de 3 dias e $90 \%$ estavam dispersas em até 11 dias.

A primeira emergência originou a maioria das ninfas (Tabela 34), ou seja, 65,60\% do total, indicando que a primeira postura foi a mais viável. As demais, originaram, respectivamente, 27,$37 ; 6,92$ e $0,11 \%$ das ninfas. 
Tabela 33. Epoca do início, intervalo e duração das dispersões das ninfas de Euophrys sutrix. Temp. $25 \pm 1,5^{\circ} \mathrm{C}$, UR $70 \pm 10 \%$ e Fotofase $11-14$ horas.

\begin{tabular}{|c|c|c|c|c|}
\hline \multirow{2}{*}{ Dispersões } & & \multicolumn{3}{|c|}{ Tempo (dias) } \\
\hline & & $\bar{x} \pm s(\bar{x})$ & Interv. Variacão & Coef. Variação \\
\hline $\begin{array}{l}\text { Iníci } \text { após } \\
\text { as cópulas }\end{array}$ & $\begin{array}{l}1 \underline{a} \\
2 \underline{a} \\
3 \underline{a} \\
4 \underline{a}{ }^{(a)}\end{array}$ & $\begin{array}{c}60,00 \pm 2,63 \\
80,29 \pm 3,45 \\
92,50 \pm 10,50 \\
92,00\end{array}$ & $\begin{array}{l}42-69 \\
63-91 \\
82-103 \\
-\end{array}$ & $\begin{array}{l}13,18 \\
11,36 \\
16,05 \\
-\end{array}$ \\
\hline Intervalo & $\begin{array}{lll}1 \underline{a} & \text { a } & 2 \underline{a} \\
2 \underline{a} & \text { a } & 3 \underline{a}\end{array}$ & $\begin{array}{l}6,29 \pm 1,15 \\
8,50 \pm 2,72\end{array}$ & $\begin{array}{l}2-12 \\
1-13\end{array}$ & $\begin{array}{l}48,35 \\
64,08\end{array}$ \\
\hline Duração & $\begin{array}{l}1 \underline{a} \\
2 \underline{a} \\
3 \underline{a} \\
4 \underline{a}^{(a)}\end{array}$ & $\begin{array}{l}14,70 \pm 1,32 \\
16,86 \pm 2,20 \\
12,00 \pm 5,00 \\
24,00\end{array}$ & $\begin{array}{r}8-20 \\
11-28 \\
7-17 \\
-\end{array}$ & $\begin{array}{l}28,33 \\
34,49 \\
58,93 \\
-\end{array}$ \\
\hline
\end{tabular}

(a) A 4a dispersão ocorreu somente para uma fêmea.

Cada fêmea fértil produziu de 41 a 179 ninfas, com média de 94 , o que resultou em 15 ninfas por ovissaco. Contudo, muitas das posturas não foram viáveis e esse número passou para 45 ninfas por ovissaco viável. Mas, considerando todos os ovissacos produzidos pelo total de fêmeas, teve-se que 11 ninfas emergiram de cada um (Tabela 34). Por isto, pode-se notar que as fêmeas produziram poucos descendentes, em relação ao total de posturas realizadas, mesmo porque, a viabilidade de ovos em relação ao total depositado foi de $23,57 \%$ e, em relação ao número depositado pelas fêmeas férteis, foi de $32,68 \%$.

De cada casulo de postura emergiram ao redor de 26 ninfas, havendo casulos que não continham posturas viáveis. Daqueles que as continham, cerca de 37 
ninfas emergiram, com uma variação de 17 a 89 ninfas por casulo (Tabela 34).

Os tipos de recipientes utilizados na criação, praticamente não influenciaram o número de descendentes (Tabela 34 ).

Tabela 34. Número de ninfas emersas de Euophrys sutrix, em relação às fêmeas, às emergências, às estruturas de postura e aos tipos de recipientes utilizados. Temp. $25 \pm 1,5^{\circ} \mathrm{C}$, UR $70 \pm 10 \%$ e Fotofase $11-14$ horas.

\begin{tabular}{|c|c|c|c|}
\hline \multirow{2}{*}{ Ninfas Emersas } & \multicolumn{3}{|c|}{ Número } \\
\hline & $\bar{x} \pm s(\bar{x})$ & $\begin{array}{l}\text { Interv. } \\
\text { Variação }\end{array}$ & $\begin{array}{l}\text { Coef. } \\
\text { Variação }\end{array}$ \\
\hline \multicolumn{4}{|l|}{ Em relação: } \\
\hline - ao total de fêmeas & $72,23 \pm 16,61$ & $0-179$ & 82,93 \\
\hline - às fêmeas férteis & $93,90 \pm 15,88$ & $41-179$ & 53,50 \\
\hline \multicolumn{4}{|l|}{ Por emergência: } \\
\hline$-1 \underline{a}$ & $61,60 \pm 6,37$ & $38-107$ & 32,68 \\
\hline$-2 \underline{a}$ & $25,70 \pm 7,88$ & $0-65$ & 97,01 \\
\hline$-3 \underline{a}_{(a)}$ & $6,50 \pm 4,91$ & $0-48$ & - \\
\hline$-4 \underline{a}^{|a|}$ & $0,10 \pm 0,10$ & $0-1$ & - \\
\hline \multicolumn{4}{|l|}{ Por ovissaco: } \\
\hline- total & $11,18 \pm 1,27$ & $0,0-59,7$ & - \\
\hline - de fêmea fértil & $15,91 \pm 1,41$ & $0,0-59,7$ & 68,29 \\
\hline - viável de fêmea fértil & $44,74 \pm 2,84$ & $20,5-59,7$ & 29,12 \\
\hline \multicolumn{4}{|l|}{ Por casulo-de-postura: } \\
\hline - com ovissaco viável & $\begin{array}{l}20,38 \pm 4,1 i \\
37,56 \pm 4,20\end{array}$ & $17,5-89,5$ & 55,90 \\
\hline \multicolumn{4}{|l|}{ Por tipo de recipiente: } \\
\hline - tubular & $93,17 \pm 21,77$ & $\begin{array}{l}41-179 \\
50-174\end{array}$ & 57,23 \\
\hline - gargalo & $95,00 \pm 26.59$ & $59-174$ & 52,98 \\
\hline
\end{tabular}

(a) A 4a dispersão ocorreu somente para uma fêmea. 


\subsection{Bioensaios}

\subsubsection{Caminhamento sobre filme-seco}

O número de ninfas (de 20 e $3 \underline{0}$ instares) que chegaram ao topo dos tubos tratados, encontra-se na Tabela 35, tendo-se observado que as ninfas restantes não deixaram os recipientes de liberação. O tempo necessário para que as ninfas caminhassem até o topo de cada tubo, não foi influenciado pelos acaricidas (Tabela 35). Por esses resultados, observou-se ainda, que os produtos testados provavelmente não causaram efeito repelente às ninfas.

$$
\text { Nenhum dos acaricidas ocasionou }
$$

mortalidade às ninfas (Tabela 35) até 50 horas após o início das 1 iberações.

Tabela 35. Número de ninfas de Euophrys sutrix, que galgaram os tubos tratados, tempo médio de caminhamento e número de ninfas mortas nos tratamentos. Jaguariúna, SP, 20-22/06/1992.

\begin{tabular}{lccc}
\hline \multirow{2}{*}{$\begin{array}{c}\text { Tratamentos } \\
\text { (i.a.) }\end{array}$} & \multicolumn{2}{c}{ Chegada ao Topo dos Tubos } & \multicolumn{1}{c}{$\begin{array}{c}\text { Nümero } \\
\text { de Ninfas } \\
\text { Mortas }\end{array}$} \\
\cline { 2 - 4 } & No de Ninfas & Tempo Médio (min) & 0 \\
1. abamectim & 7 & 30,0 & 0 \\
2. bifentrim & 8 & 31,5 & 1 \\
3. cihexatim & 9 & 54,5 & 0 \\
4. dicofol & 10 & 39,5 & 0 \\
5. ox. fembutatina & 9 & 49.5 & 0 \\
6. propargite & 10 & 49,5 & 1 \\
7. testemunha & 8 & 54,5 & \\
\hline
\end{tabular}




\subsubsection{Imersão}

\subsubsection{Imersão I (dosagens recomendadas)}

Na Tabela 36 encontram-se os resultados do bioensaio, tendo-se obtido que na avaliação de toxicidade aguda $(24 \mathrm{~h})$ houve significativa diferença na mortalidade apenas para bifentrim. Este acaricida causou $100 \%$ de mortalidade, sendo portanto tóxico ou não seletivo. José (1992) considerou esse produto como não seletivo para aranhas e ALINIAZEE \& CRANHAM (1980) relataram que os piretróides foram incompatíveis para o manejo de pragas de macieiras.

Abamectim, que foi inócuo na avaliação de 24 horas, passou a levemente tóxico no 6ㅇ dia, moderadamente tóxico no 10 dia e tóxico no $13 \underline{\text { Q }}$ dia, quando causou mortalidade de $100 \%$ das ninfas de 20 instar.

Cihexatim permaneceu inócuo até o final das avaliações mesmo tendo, nesta época, ocasionado $25 \%$ de mortalidade. Dicofol, óxido de fembutatina e propargite não causaram mortalidade de ninfas. sendo lambém inócuos. José (1992) obteve que dicofol e bxido de fembutatina foram seletivos a a ranhas e JEPPSON et ali (1975) obtiveram que propargite foj o produto menos tóxico para o ácaro predador Amblyseius hibisci (Chant.). HASSAN et ali i (1983) consideraram óxido de fembutatina inofensivo a inimigos naturais. recomendando-o em programas de manejo integrado. 
Tabela 36. Mortalidade de ninfas de 20 instar de Euophrys sutrix, tratadas por imersão, com acaricidas em dosagens recomendadas para controle de ácaros em citros. Jaguariúna, SP, 09-24/07/1992.

\begin{tabular}{lrrrrrrr}
\hline & \multicolumn{7}{c}{ Mortalidade Acumulada (\%), nas Avaliações } \\
\cline { 2 - 7 } $\begin{array}{c}\text { Tratamentos } \\
\text { (i.a.) }\end{array}$ & 24 horas & $(1)$ & 4 dias & 6 dias & 10 dias & 13 dias & 15 dias \\
\hline 1. abamectim & 25,00 & $b$ & 25,00 & 75,00 & 87,50 & 100,00 & 100,00 \\
2. bifentrim & $100,00 \mathrm{a}$ & 100,00 & 100,00 & 100,00 & 100,00 & 100,00 \\
3. cihexatim & 12,50 & $\mathrm{~b}$ & 12,50 & 12,50 & 12,50 & 12,50 & 25,00 \\
4. dicofol & 0,00 & $\mathrm{~b}$ & 0,00 & 0,00 & 0,00 & 0,00 & 0,00 \\
5. Ox. fembutatina & 0,00 & $\mathrm{~b}$ & 0,00 & 0,00 & 0,00 & 0,00 & 0,00 \\
6. propargite & 0,00 & $\mathrm{~b}$ & 0,00 & 0,00 & 0,00 & 0,00 & 0,00 \\
7. testemunha & 0,00 & $\mathrm{~b}$ & 0,00 & 0,00 & 0,00 & 0,00 & 0,00 \\
\hline
\end{tabular}

(1) Porcentagens seguidas pelas mesmas letras não diferem significativamente entre si (Tukey 5\%).

\subsubsection{Imersão II (dosagens duplas)}

Nesse ensaio, a toxicidade aguda de abamectim e cihexatim não diferiram estatisticamente entre si, diferindo dos demais tratamentos. Contudo, em relação às suas toxicidades (escala de HASSAN et alii, 1987), abamectim foi levemente tóxico e cihexatim moderadamente tóxico (Tabela 37 ).

Ao longo das avaliações, abamectim apresentou mortalidade crescente, atingindo $100 \%, 72$ horas após a mergulhia das ninfas, passando a ser classificado como tóxico ou não seletivo. Para cihexatim a mortalidade ocorrida inicialmente se manteve até o 180 dia, permanecendo como moderadamente tóxico.

Dicofol e óxido de fembutatina foram 
inócuos, mesmo em dosagens duplas, apesar de terem causado, respectivamente, $12,5 \%$ e $25,0 \%$ de mortalidade de ninfas, 48 horas após a mergulhia. Propargite também foi inócuo, não causando a morte de ninfas, até 18 dias.

Tabela 37. Mortalidade de ninfas de 20 instar de Euophrys sutrix, tratadas por imersão, com acaricidas em dosagens duas vezes maiores que as recomendadas para controle de ácaros em citros. Jaguariúna, SP, 16/07-03/08/1992.

\begin{tabular}{|c|c|c|c|c|c|}
\hline \multirow{2}{*}{$\begin{array}{l}\text { Tratamentos } \\
\text { (i.a.) }\end{array}$} & \multicolumn{5}{|c|}{ Mortalidade Acumulada (\%), nas Avaliações } \\
\hline & $24 \operatorname{horas}^{(1)}$ & 48 horas & 72 horas & . . & 18 dias \\
\hline 1. abamect im & $62,50 \mathrm{a}$ & 75,00 & 100,00 & & 100,00 \\
\hline 2. cihexatim & 87,50 a & 87,50 & 87,50 & & 87,50 \\
\hline 3. dicofol & $0,00 \mathrm{~b}$ & 12,50 & 12,50 & & 12,50 \\
\hline 4. ox. fembutatina & 12,50 & 25,00 & 25,00 & & 25,00 \\
\hline 5. propargite & 0,00 & 0,00 & 0,00 & & 0,00 \\
\hline 6. testemunha & 0,00 & 0,00 & 0,00 & & 0,00 \\
\hline
\end{tabular}

\subsubsection{Exposição a filme-Seco}

O bifentrim diferiu estatisticamente dos demais tratamentos na primeira avaliação, quando ocasionou $100 \%$ de mortalidade de ninfas, sendo portanto considerado tóxico. Os demais tratamentos foram inócuos, sendo que abamectim e óxido de fembutatina não causaram mortalidade 
até 15 dias após o contato inicial (Tabela 38).

Bifentrim continuou tóxico 13 dias após aplicado, ocorrendo $100 \%$ de mortalidade de ninfas, 20 horas depois de sua introdução nos tubos tratados.

Tabela 38. Mortalidade de ninfas de 20 instar de Euophrys sutrix, submetidas à exposição a filme seco de acaricidas recomendados para controle de ácaros em citros. Jaguariúna, SP, 13-28/08/1992.

\begin{tabular}{|c|c|c|c|c|c|c|c|c|c|}
\hline \multirow{2}{*}{$\begin{array}{c}\text { Tratamentos } \\
\text { (i.a.) }\end{array}$} & \multicolumn{9}{|c|}{ Mortalidade Acumulada(\%), nas Avaliações } \\
\hline & 24 horas & $s^{(1)}$ & 48 & horas & 72 & horas & 5 dias & 10 dias & 15 dias \\
\hline 1. abamectim & 0.00 & b & & 0,00 & & 0,00 & 0,00 & 0,00 & 0,00 \\
\hline 2. bifentrim & $100,00:$ & a & & 100,00 & & 100,00 & 100,00 & 100,00 & 100,00 \\
\hline 3. cihexatim & 20,00 & $b$ & & 20,00 & & 20,00 & 20,00 & 20,00 & 20,00 \\
\hline 4. dicofol & 0,00 & $b$ & & 0,00 & & 10,00 & 10,00 & 10,00 & 10,00 \\
\hline 5. ox. fembutat ina & 0,00 & $b$ & & 0,00 & & 0,00 & 0,00 & 0,00 & 0,00 \\
\hline 6. propargite & 0,00 & $b$ & & 0,00 & & 0,00 & 0,00 & 10,00 & 10,00 \\
\hline 7. test emunha & 0,00 & $b$ & & 0,00 & & 0,00 & 0,00 & 0,00 & 0,00 \\
\hline
\end{tabular}

(1) Porcentagens seguidas pelas mesmas letras não diferem significativamente entre si (Tukey 5\%).

4.3.4. Considerações gerais dos resultados dos bioensaios

Pelos resultados alcançados combifentrim no teste de Exposição a Filme-Seco, concluiu-se que não ocorreu mortalidade no teste de Caminhamento sobre FilmeSeco, porque o rápido contato tarsal com a área tratada e seca, não foi suficiente para penetração e conseqüente intoxicacão das ninfas. 
A seguir, são feitas algumas considerações para cada um dos ingredientes ativos testados.

\section{Abamect im}

Considerando-se somente a toxicidade aguda do abamectim para ninfas de E. sutrix, esse acaricida seria seletivo por dosagem e por ingrediente ativo, levando em conta os resultados obtidos nos ensaios de Imersão. Da mesma forma esse ingrediente ativo seria considerado como seletivo, se testado somente pelo método de Exposição a Filme-Seco quando, a lém de ter sido inócuo às ninfas, não apresentou efeito subletal.

Porém, nos ensaios de Imersão, observou-se que as ninfas sobreviventes apresentaram comportamento que diferia da Testemunha: mostravam-se relativamente lentas, não se alimentando e permanecendo por longos períodos na base do recipiente, não subindo pelas paredes, indicando intoxicação. Tanto que, no primeiro ensaio de Imersão, houve aumento da mortalidade após quatro dias, atingindo $100 \%$ aos 13 dias.

Por esse efeito retardado, o abamectim foi considerado tóxico e portanto não seletivo a aranhas de $2 \varrho$ ínstar, que tivessem seus corpos diretamente atingidos pelas gotas pulverizadas, contendo o ingrediente ativo. Essa ação do abamectim ficou clara, quando, no teste de Exposição a Filme-Seco, não ocorreu morte e nem intoxicação das ninfas. 
Supoz-se que aquela intoxicação, observada no teste de Imersão, ocorreu via espiráculo ou via ingestão, esta possivelmente através das peças bucais, que se contaminaram durante o processo de 1 impeza das pernas anteriores das ninfas. ROACH \& MOORE (1988) discutiram a ação de ingestão do abamectim, quando obtiveram que $83 \%$ das aranhas da espécie P. audax, alimentadas com larvas de Helicoverpa zea (Boddie) criadas em dietas contendo $10 \mathrm{ppm}$ de abamectim, ficaram entorpecidas ou moribundas num período de 48 horas.

\section{Bifentrim}

O bifentrim foi tóxico, tanto por via direta como indireta, podendo-se considerá-lo como não seletivo a ninfas de 20 ínstar de E. sutrix. Além disso, sua atividade tóxica prolongou-se, em laboratório, por no mínimo 13 dias após aplicado.

\section{Cihexat im}

Haja visto os resultados de mortalidade de ninfas nos ensaios de Imersão I e Exposição a Filme-Seco, esse acaricida poderia se considerado como inócuo e portanto seletivo por dosagem. Porém, as aranhas que receberam esse tratamento, apresentaram a lteração de comportamento, ficando mais vagarosas durante o espaço de 24 horas após o contato. Embora as ninfas tenham se recuperado posteriormente, esse 
efeito poderia, no campo, resultar em fracasso tanto na captura de presas como na fuga de hostilidades, já que a espécie, por ser caçadora e saltadora, depende extremamente de sua agilidade para a sobrevivência. Levando isso em conta, desconsiderou-se a seletividade do cihexatim a ninfas de 20 instar de E. sutrix.

Dicofol, óxido de Fembutatina e Propargite

Esses ingredientes ativos foram inócuos às ninfas de E. sutrix em todos os testes, não apresentando efeitos colaterais, sendo portanto considerados seletivos. 


\section{CONCLUSÕES}

- As ninfas apresentam no máximo 8 instares, durante 208 dias, passando metade desse tempo em atividade; os adultos têm longevidade de 161 dias e o ciclo biológico é de 287 dias;

- A viabilidade de ovos das fêmeas férteis é de 33\%, originando 94 ninfas $I$, por fêmea;

- A mortalidade ninfal é de $87 \%$, causada principalmente por insucessos nas ecdises;

- A dieta das ninfas, predominantemente de Drosophyla sp., não é nutricionalmente adequada, influenciando a sua sobrevivência e o tamanho, a fertilidade e a longevidade dos adultos;

- Bifentrim é o mais tóxico dos produtos testados para ninfas de segundo ínstar, tanto por contato direto, como indireto;

- Abamectim é tóxico por contato direto e inócuo por contato indireto;

- Cihexatim é tóxico, porque causa alterậão no comportamento das ninfas:

- Dicofol. óxido de fembutatina propargite são inócuos: 
- O longo ciclo de vida da espécie torna-a mais suscetível à ação dos acaricidas não seletivos utilizados em citricultura. 


\section{REFERENCIAS BIBLIOGRAFICAS}

ALINIAZZE, N.T. \& CRANHAM, J.E. Effect of four synthetic pyrethroids on a predadory mite, Typhlodromus pyri and its prey, Panonychus ulmi on apples in Southeast England. Environ. Entomo1. Lanham, 9(4): 436-9, 1980.

BAILEY, C.L. \& CHADA. H.L. Spider population in grains sorghums. Ann. Entomol. Soc. Am., College Park, 61(3): $567-71,1968$

BELARMINO, L.C.; MORAES, R.R.; LEONEL JT., F.L. Reduções nas populações naturais de predadores e trichogramatídeos em soja por inseticidas. In: CONGRESSO BRASILEIRO DE ENTOMOLOGiA, 13., Recife, 1991. Resumos. Recife, SEB, 1991. v.1, p.321.

BERTOLDO, N.G. \& CAETANO, W. Impacto de diferentes inseticidas sobra a entomofauna benéfica em soja. In: CONGRESSO BRASILEIRO DE ENTOMOLOGIA, 13., Recife, 1991. Resumos. Recife, SEB, 1991. v.1, p.304. 
BOSTANIAN, N.J.; DONDALE, C.D.; BINNS, M.R.; PITRE, D. Effects of pesticide use on spiders (Araneae) in Quebec apple orchards. Can. Entomo1., Ottawa, 116(5):663-75, 1984 .

CAETANo, A.A. Tratamento fitossanitário do pomar cítrico. In: RODRIGUEZ, O. \& VIEGAS, F. Citricultura brasileira. Campinas, Fundação Cargill, 1980. v.2, p.623-41.

CARROL, D.P. Biological notes on the spiders of some citrus groves in central and southern California. Entomol. News, Philadelphia, 91(5): 147-54, 1980 .

CATI. Coordenadoria de Assistência Técnica Integral. Comissão de Avaliação de Defensivos para uso em citricultura. Citros: Recomendações para o controle das principais pragas e doenças em pomares do Estado de São Paulo. 4.ed. Campinas, 1991. 55p. (Boletim Técnico, $165)$

COMSTOCK, J.H. The spider book. Ithaca, Comstock Publishing Company, 1948. 729 .

CRANE: J. Comparative biology os salticid spiders at Rancho Grande. Venezuela. Pt.1. Systematics and life histories in Corythalia. Zoologica, Stuttgart. 33: 1-38, 1948. 
DEAN, D.A.; STERLING, W.L.; HORNER, N.V. Spiders in eastern Texas cotton fields. J. Arachnol., New York, 10: $251-60,1982$.

DONDALE, C.D. Life histories and distribution patterns of hunting spiders (Araneida) in an ontario meadow. J . Arachonol., New York, 4: 73-93, 1977.

DONDALE, C.D.; PARENT, B.: PITRE, D. A 6-year study of spiders (Araneae) in a Quebec apple orchard. Can. Entomol., Ot tawa, 111(3): 377-80, 1979 .

FOELIX, R.F. Biology of spiders. Cambridge, Harvard University Press, 1982. $306 p$.

GALIANO, M.E. Nota sobre el género Evophrys Koch, 1834 (Araneae, Salticidae). Physis, Buenos Aires, 23(65): $169-83,1962$

GARDNER, B.T. The life cycle of the spider, Phidippus coccineus (Salticidae) under laboratory condictions. Psyche, Cambridge, 74: 104-6, 1967 .

GONZALEZ, A. \& ESTEVEZ, A.L. Estudio del desarrollo postembrionario $y$ estadísticos vitales de Theridion rufipes Lucas, 1846 (Araneae, Therididae). Rev. Bras. Ent.. São Paulo, 32(3/4): 499-506. 1988. 
GUILLEN, E.E.A. Efeito de inseticidas sobre as pragas da soja e seus predadores. Curitiba, 1977. 133p. (Mestrado - Universidade Federal do Paraná).

HASSAN, S.A.; BIGLER, F.; BOGENSCHÜTZ, H. ; BROWN, J.U.; FIRTH， S.I .; HUAND， P.; LEDIEU， M.S . ; NATON , E , ; OOMEN, P.A.; OVERMEER, W.P.J.; RIECHMANN, W.; SAMSOE PETERSEN, L.; VIGGIANI, G.; VANZON, A.Q. Results of the second joint pesticide testing programme by the IOBC/WPRS Working Group "Pesticides and Beneficial Arthropods". Zeitschrift für Angewandte Entomologie, Hamburg, 95: 151$8,1983$.

HASSAN, S.A.; ALBERT, R.; BIGLER, F.; BLAISINGER, P.; BOGENSCHÜTZ, H. ; BOLLER, E .; BRUN , J .; CHIVERTON, P.; EDWARDS, P. ; ENGLERT, W.D.; HUANG, P.; I NGLESFIELD. C .; NATON, E .; OOMEN, P.A.; OVERMEER, W.P.J .; RIECKMANN, W .; SAMSOE-PETERSEN, L . ; STAUBL I, A . ; TUSET; J . J . ; VIGGIANI, G.; VANWETSWINKEL, G. Results of the third joint pesticide testing programme by the IOBC/WPRS - working Group "Pesticides and Beneficial Organisms". J. Appl. Entomo 1., Hamburg, 103: 92-107, 1987.

HORNER, N.V. Metaphidippus galathea as a possible biological control agent. J. Kansas Entomol. Soc., Lawrence, 45(3): 324-7, 1972. 
HORNER, N.V. \& STARKS, K.J. Bionomics of the jumping spider Metaphidippus galathea. Ann. Entomol. Soc. Am., College Park, 65(3): 602-7, 1972 .

HOWELL, J.O. \& PIENKOWSKI, R.L. Spider populations in alfafa, with notes on spider prey and effect of harvest. J. Econon. Entom., College Park, 64(1): 163-8, 1971 .

JENNINGS, D.T. \& PASE, H.A. Spiders preying on Dendroctomus frontalis (Coleoptera: Scolytidae). Entomol. News, Philadelphia, $97(5): 227-9,1986$.

JEPPSON, L.R.; MCMURTHY, J.A.; MEAD, D.W.; JESSER, M.J .; JOHNSON. H.G. Toxicity of citrus pesticides to some predaceous phytoseid mites. J. Econ. Entomol., Lanhan, $68(5): 707-10,1975$.

JOSÉ, L.A.A. Seletividade de piretróides acaricidas a inimigos naturais de pragas de citros. Piracicaba, 1992. 104p. (Mestrado - Escola Superior de Agricultura "Luiz de Queiroz"/USP).

KASTON, B.J. \& KASTON, E. How to know the spiders. s. 1. H.E. J aques, 1953. $219 \mathrm{p}$. 
LASTER, M.L. \& BRAZZEL, J.R. A comparison of predator populations in cotton under different control programs in MIssissipi. J. Econ. Entomo1., College Park, 61(3): 7149,1968 .

LEONEL Jr., F.L.; ALMEIDA, T.O.M. de; SCHROTER, R.A.; PEREZ, C.A. Resultados de experimentos visando estudar o impacto do inseticida Tifon $250 \mathrm{SC}$ sobre o complexo de predadores da soja. In: CONGRESSO BRASILEIRO DE ENTOMOLOGia, 13., Recife, 1991. Resumos. Recife, SEB, 1991. v. 1, p.320.

MANSOUR, F. A malathion-tolerant strain of the spider Chiracanthium mildei and its response to chlorpyrifos. Phitoparasitica, Bet Dagan, 12 (3-4): 163-6, 1984.

MANSOUR, F. \& WH ITCOMB, W.H. The spiders of a citrus grove in Israel and their role as biocontrol agents of Ceroplastes floridensis (Homoptera : Coccidae) Entomophaga, Paris, 31(3): 269-76, 1986.

MCCAFFREY, J.P. \& HORSBURGH, R.L. The spider fauna of apple trees in central Virginia. Environ. Entomol., College Park, 9(2): 247-52, 1980 . 
MCDANIEL, S.G. \& STERLING, W.L. Predation of Heliothis virescens (F.) eggs on cotton in east Texas. Environ. Entomol., College Park, 11 (1): 60-6, 1982.

MERRET, P. The phenology of spiders on healthland in Dorset. I. Families Atypidae, Dysderidae, Gnaphosidae, Clubionidae, Thomisidae and Salticidae. J. Anim. Ecol., Oxford, 36: 363-74, 1967 .

MOREIRA, C.S. Panorama geral da citricultura no Brasil, In: MOREIRA, C.S.; MALAVOLTA, E.; RODRIGUEZ, O.; SANCHES, A.C.; KOO, R.C.J. Nutrição mineral e adubação dos citros. 4.ed. Piracicaba, Instituto da Potassa, 1983. p.1-12 (Boletim Técnico, 5).

NYFFELER, M. \& BENZ, G. Spiders in natural pest control: a review. J. Appl. Entomo1., Hamburg, 103: 331-9, 1987.

PAPA, G.; SANTOS, M.C.; NAKANO, O. Ação de alguns acaricidas sobre os inimigos naturais presentes em pomar de citros. In: CONGREsso BRAsileiro DE ENTOMOLOGIA, 13. , Recife, 1991. Resumos. Recife, SEB. 1991. v.1, p.306.

RIECHERT, S.E. \& LOCKLEY, T. Spiders as biological control agents. Ann. Rev. Entomol.. Palo Alto, 29: 299-320, 1984. 
ROACH, S.H. Susceptibility of Oxyopes salticus Hentz and Phidippus audax Hentz (Araneae : Oxyopidae, Salticidae) to fenvalerate, azinphos methyl, and methyl parathion. J. Georgia Entomol. Soc., Tifton, 18(3): 326., 1983.

ROACH, S.H. Reproductive periods of Phidippus species (Araneae, Salticidae) in South Carolina. J. Arachnol., 16: $95-101,1988$.

ROACH, S.H. \& MOORE, R.F. Effects of abamectin on Phidippus audax (Hentz) (Araneae: Salticidae) when ingested from prey. J. Entomo1. Sci., 23(2): 112-6, 1988 .

ROBINSON, M.H. Courtship and mating behavior in spiders. Ann. Rev . Entomol ., 27: 1-20, 1982 .

SALVADORI, J.R. \& GOMEZ, S.A. Abundância estacional de insetos pragas da soja e seus inimigos naturais em Dourados, MS. In: SEMINARIO NACIONAL DE PESQUISA DE SoJA, 1., Londrina, 1978. Anais. Londrina, EMBRAPACNPSO, 1978 . p. 17-50.

SANTOS. B.B.; FOERSTER, L.A.; SMITH, J.G. Ocotrência estacional de insetos-pragas da soja e seus predadores no centro sul do Paraná. In: SEMINARIO NACIONAL DE PESQUisA DE SOJA, 1., Londrina, 1978. Anais. Londrina, EMBRAPACNPSO, 1978. p. 29-38. 
SPECHT, H.B. \& DONDALE, C.D. Spider population in New Jersey apple orchards. J. Econ. Entomol., College Park, $53(5): 810-7,1960$.

WHITCOMB，W.H. \& TADIC, M. Araneida as predators of the fall webworm. J. Kansas Entomol. Soc., Lawrence, 36(3): 186-90, 1963.

WH I TCOMB, W.H. The use of predators in insect control. In: PIMENTEL, D. Handbook of pest management in agriculture. Boca Raton, CRC Press, 1981. v.2, p.105-23.

WHITFORD, F.; SHOWERS, W.B.; EDWARDS, G.B. Insecticide tolerance of ground-and-foliage-dweeling spiders (Araneae) in european corn borer (Lepidoptera: Pyralidae) action sites. Environ. Entomol., College Park, 16(3): 779-85, 1987 . 